\title{
Contextualizing Early Urbanization: Settlement Cores, Early States and Agro-pastoral Strategies in the Fertile Crescent During the Fourth and Third Millennia BC
}

\author{
T. J. Wilkinson • Graham Philip · J. Bradbury • R. Dunford • \\ D. Donoghue $\cdot$ N. Galiatsatos $\cdot$ D. Lawrence $\cdot$ A. Ricci $・$ \\ S. L. Smith
}

Published online: 16 April 2014

(C) The Author(s) 2014. This article is published with open access at Springerlink.com

\begin{abstract}
This paper employs data from selected sample survey areas in the northern Fertile Crescent to demonstrate how initial urbanization developed along several pathways. The first, during the Late Chalcolithic period, was within a dense pattern of rural settlement. There followed a profound shift in settlement pattern that resulted in the formation of large walled or ramparted sites ('citadel cities') associated with a more dynamic phase of urbanization exemplified by short cycles of growth and collapse. By the later third millennium BC, the distribution of larger centres had expanded to include the drier agropastoral zone of northern and central Syria, termed here the 'zone of uncertainty'. This configuration, in turn, formed the context for Middle Bronze Age settlement, and the pattern of political rivalries and alliances that typified the second millennium BC. Evidence is marshalled from archaeological surveys and landscape analyses to examine these multiple paths to urbanization from the perspectives of (a) staple production within major
\end{abstract}

T. J. Wilkinson $(凹) \cdot$ G. Philip · J. Bradbury · D. Lawrence $\cdot$ S. L. Smith Department of Archaeology, Durham University, Durham DH1 3LE, UK e-mail: t.j.wilkinson@durham.ac.uk

G. Philip

e-mail: graham.philip@durham.ac.uk

J. Bradbury

e-mail: j.n.bradbury@durham.ac.uk

D. Lawrence

e-mail: dan.lawrence@durham.ac.uk

S. L. Smith

e-mail: stefan.smith@dunelm.org.uk

R. Dunford

OUCE, Environmental Change Unit, Oxford University, South Parks Road, Oxford OX1 3QY, UK e-mail: robert.dunford@ouce.ox.ac.uk

D. Donoghue $\cdot$ N. Galiatsatos

Department of Geography, Durham University, Durham DH1 3LE, UK

e-mail: danny.donoghue@durham.ac.uk 
agricultural lowlands; (b) the shift towards higher risk animal husbandry within climatically marginal regions; (c) changes in local and inter-regional networks (connectivity); and (d) ties and rights to the land. Textile production forms the core of the proposed model, which emphasizes how the demand for wool and associated pasture lands opened up new landscapes for agro-pastoral production and settlement. The resultant landscapes of settlement are then compared with the picture in the southern Levant where a more restricted zone of uncertainty may have limited the opportunities for agro-pastoral production.

Keywords Cities - Landscape $\cdot$ Agro-pastoral $\cdot$ Late Chalcolithic $\cdot$ Bronze Age $\cdot$ Wool $\cdot$ Urbanization

\section{Introduction}

Urbanization and state formation have formed a central pillar of the discussion of the development of ancient Near Eastern civilizations, but this debate has frequently become polarised between evolutionary models (e.g. Flannery 1999) and more historically contingent models of processes of development (e.g. Yoffee 2005; Yoffee et al. 2005). City and state development are inherently regional phenomena, and more recent discussions of North Mesopotamian urbanism, in addition to focusing upon excavation, cuneiform texts and material culture, also include the increasing evidence of settlement patterns from regional surveys throughout the northern Fertile Crescent (Wilkinson 2000a; Casana 2007; Ur 2010a; Matney 2012; McMahon 2013, pp. 464-465; Philip 2007). The primary aim of this paper is to supplement these earlier summaries with data drawn from the Fragile Crescent Project (FCP) to produce a broad synthesis of regional settlement throughout North Mesopotamia and the Levant. These FCP data sources contextualize the development of early urbanization and help identify and explain the distinct settlement trajectories of different sub-regions of the northern and western Fertile Crescent. Emphasis is placed upon bringing together the landscape evidence from such surveys with the substantial record of agro-pastoral activities, textile production and archaeological evidence from sites ranging in size from 0.5 to 120 ha. Specifically, we examine the context of rural settlement within which proto-urban settlements developed, in order to draw a distinction between those major centres which grew up in regions where populations were already dense and those which did not.

The FCP has employed archaeological survey data from the Northern Fertile Crescent, and re-interrogated these data using remote sensing and supplementary ground-based data sources in order to check and improve the quality of the original surveys (Galiatsatos et al. 2009). The resultant enhanced data set has then been analyzed within a GIS-linked

N. Galiatsatos

e-mail: nikolaos.galiatsatos@durham.ac.uk

A. Ricci

Graduate School 'Human Development in Landscapes', Christian Albrecht Universität zur Kiel, Kiel, Germany

e-mail: aricci@gshdl.uni-kiel.de

A. Ricci

Eurasia Department, German Archaeological Institute, Berlin, Germany 
database to identify long-term settlement trends extending from northwestern Iraq to western Syria. Because variations in regional chronologies have impeded our ability to make comparisons between the various phases of urbanization, the FCP has developed database and temporal modelling techniques which make it possible to compare trends in settlement between regions.

Although this discussion relies upon three main classes of evidence-excavation, ancient texts, and surveys-here we focus on the last named source. Evidence is marshalled from a series of archaeological surveys and landscape analyses to examine phases of urbanization from the three perspectives (loosely based on those employed by Horden and Purcell) of, first, a historical-ecological approach based around micro-regions; second, perceptions and strategies for coping with risk and uncertainty; and, third, connectivity (Horden and Purcell 2000, p. 10). In addition, our chosen framework builds upon the concept of the 'three-sector economy.' Whereas the original three-sector model (Wilkinson 2000b, pp. 6-14) subdivided the economy of North Mesopotamia into (a) the staple economy; (b) the pastoral economy and wealth based upon it; and (c) networks and the trade and wealth that moved along them, the proposed analytical framework is underpinned by variations of the ecological regions and their different exploitation through time. The four themes framing the following narrative are:

1. The physical and socio-economic landscapes. Specifically, we highlight agricultural lowlands ('cores') which developed into 'landscapes of tells'; river valley networks; a range of 'sub-optimal landscapes'; and climatically marginal agro-pastoral areas adjacent to the main cores (referred to as the 'zone of uncertainty': see definition below).

2. The changing role of the agricultural economy and perceptions of risk, especially in driving change in the agro-pastoral zone (Stein 2004).

3. The role of 'connectivity', namely the way in which change in any one area may have a significant impact upon developments in physically discrete, even distant regions, through specific social, political or economic connections (Horden and Purcell 2000, pp. 123). Here we summarize both empirical evidence of communication networks and more abstract notions of connectivity that tie regions together via localized movements.

4. The ways in which ties to the landscape were manifest, either through functional relationships to the land through agriculture and settlement, including fortifications (Rey 2012), or by the marking of rights over the land through the construction of monuments for burial or other purposes (Philip 2003; Bradbury and Philip 2011).

The above perspectives are employed to describe and contextualize the two main phases of urbanization recognized for the Fertile Crescent (Akkermans and Schwartz 2003; Ur 2010a):

1. In the north, an initial phase of Late Chalcolithic urbanism in the fourth millennium BC consisted of the development of high and bulky mounds (Algaze 2008, p. 118).

2. This was followed by a later phase of what is frequently referred to as secondary urbanization in the mid-late third millennium. This later phase was characterized by the development of extensive and usually walled cities, which grew rapidly and then collapsed back to their central tells (Akkermans and Schwartz 2003; Ur 2010a; Matney 2012; Cooper 2006, pp. 74-78). Cities of this later phase ranged in extent between 30 and 120 ha (Wilkinson 1994; Stein 2004, table 5.1; Pfälzner 2010). 
In the southern Levant, following expansion of settlement into the uplands in the later fifth and fourth millennia BC, the late fourth millennium BC witnessed the development of large $(20 \mathrm{ha}+)$ settlements in key lowlands, followed by an early-mid third millennium $\mathrm{BC}$ expansion of settlement into a range of less reliable zones. The failure of this southern system around the middle of the third millennium BC serves to underline the very particular and contrasting character of the landscape of North Mesopotamia, where the mid third millennium BC was a period of marked settlement expansion. The direct comparison between the southern and northern Fertile Crescent has been facilitated by the publication of new radiometric and palaeoenvironmental frameworks (Bar-Matthews and Ayalon 2011; Regev et al. 2012).

Quantified data from the multiple survey areas help define these two distinct phases of urbanization in the northern Fertile Crescent, by enabling the analysis of data from all regions within a single diachronic framework. Emphasis here is upon the definition of what we term core settlement regions of early urbanization, in addition to more sparsely settled regions and valley networks which presented a different trajectory of urbanization. Rather than define a single explanatory model, this paper emphasizes local variations as well as inter-regional trends in settlement (Algaze 1999; Wilkinson 2000a, b). The results from the northern Fertile Crescent are then compared with a more general synopsis of settlement trends from the southern Levant in order to contextualize them, provide a degree of comparison, and explore some of the resultant opportunities for furthering our understanding of developing inter-regional connectivity.

\section{Phases and Circumstances of Urbanization}

Striking differences between the settlement trajectories of different parts of North Mesopotamia have become clear over the past decade (Algaze 1999; Wilkinson 2000a; Ur 2010a). For example, recent publications demonstrate that urbanization in the Khabur drainage basin of northeastern Syria exhibits deep roots, which extended well back into the fourth and fifth millennia BC (Ur et al. 2011; al-Quntar et al. 2011; Stein 2012), whereas in the environmentally marginal steppe between the Balikh and Khabur Rivers, urban-scale settlement did not develop until the early third millennium BC (Meyer 2010b; Table 1). In western Syria, while the 'Second Urban Revolution' of the mid third millennium BC is well documented at Ebla, Qatna and sites in the Amuq (Fig. 1; Akkermans and Schwartz 2003, pp. 233-246), an early florescence is more elusive. For example, fieldwork around Homs suggests that while there was a significant increase in settlement during the fourth millennium BC in the marl landscapes east of the Orontes, this was not associated with the development of urban-scale sites. This expansion was followed by a phase of settlement agglomeration during the earlier third millennium BC (Philip and Bradbury 2010, p. 161), whereas in the climatically marginal steppe to the east (that is, within central Syria), settlement expansion was even later, namely during the later third millennium BC (Early Bronze Age [EB] IV) (Geyer et al. 2007; Morandi Bonacossi 2007; Philip and Bradbury 2010, p. 162). In fact, the largest site in the region, Qatna, although perhaps 25 ha in area in EB IV (Table 1), did not attain its maximum size of 100 ha until the Middle Bronze Age (Morandi Bonacossi 2007, pp. 70-71). Therefore, in contrast to the apparent stability of the Late Chalcolithic landscape, the pattern of settlement and landscape development of the third millennium BC across the entire region was remarkably dynamic, with the explosive growth and collapse of cities, the settlement of climatically marginal lands, and an apparent increase in connectivity over the entire region. Whereas the collapse of parts of 
Table 1 Chronological table from c. 4700-1800 (Color table online)

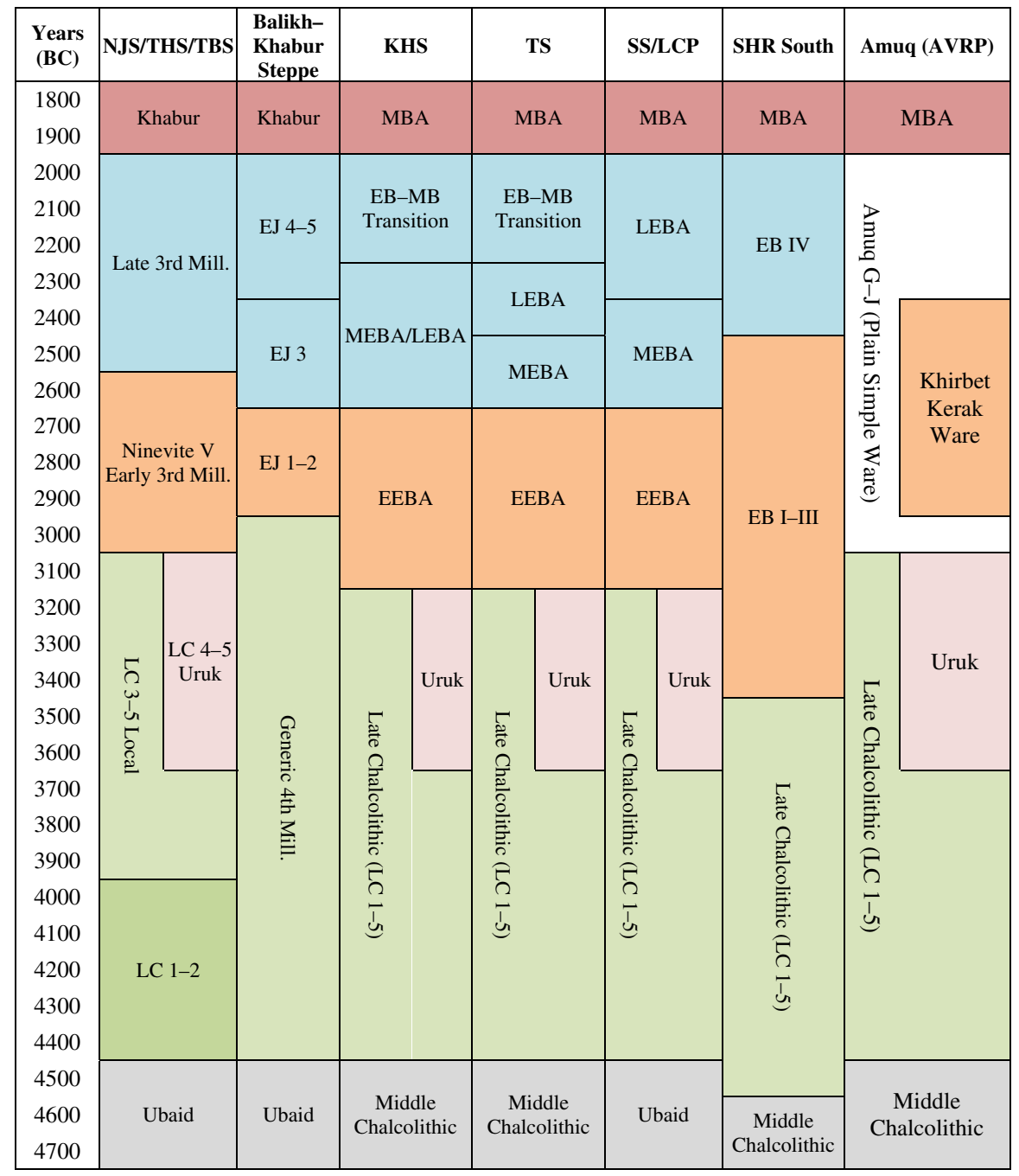

From east (left) to west (right): NJS North Jazira Survey (Iraq), THS Hamoukar Survey (NE Syria), TBS Tell Beydar Survey (Syria), KHS Kurban Höyük survey, TS Titriş survey, SS/LCP Sweyhat/Land of Carchemish surveys, SHR Homs region, AVRP Amuq Valley Regional Project, EJ Early Jazira sequence used in the text

the settlement system has been discussed from numerous perspectives (Weiss et al. 1993; Zettler 2003; Kuzucuoğlu and Marro 2007; Wossink 2009; Pfälzner 2010; McMahon 2012), the growth part of the cycle has received less attention. As discussed below, such cycles are, in part, dependent upon the size of the settlements being discussed.

In northern Syria, by the earlier fourth millennium BC (Late Chalcolithic [LC] 2), monumental architecture, formalized long-distance trade, specialized craft production and large population aggregates were in evidence in northern Mesopotamia (Algaze 1993; 2008, pp. 68-73, 99; Schwartz 2001; Ur 2010a, p. 394). These features were supplemented 
Fig. 1 a Location of project areas and the main sites and geographical features discussed in the text from the Mediterranean Sea to the Tigris River. b Inset map indicates the location of the sites in the southern Levant. Note that black stars indicate the climate proxy records at Soreq Cave (to S) and Lake Van (to N)

in LC 3-4 by evidence for religious institutions, feasting, mass production of ceramics, glyptic with leadership symbols, organized violence and urban-scale settlement (Algaze 1993; McMahon et al. 2011; Stein 1999; Schwartz 2001; Ur 2010a, p. 394; Stein 2012, p. 146). Unlike in southern Mesopotamia and southwestern Iran, evidence for writing is minimal until around the mid third millennium BC.

The emergence of urbanization at the key fourth millennium centre of Tell Brak (Fig. 1) appears to have been an indigenous phenomenon, contemporary with or even preceding the development of cities in southern Mesopotamia (Oates et al. 2007; Ur et al. 2007, p. 1188; Emberling 2003). In contrast, urbanization within the third millennium states not only occurred in the context of the use of writing, and the existence of complex social and economic organization, but also witnessed the construction of monumental buildings within public quarters as at Tells Beydar, Leilan, Mozan and Brak (Lebeau 2003; Weiss 1989; Pfälzner 2010; Oates et al. 2001). The latter are exemplified by the systematically laid-out public buildings sector on the high mound at Tell Beydar, a development which must have limited the amount of available space for domestic dwellings (Lebeau and Suleiman 2007). By the mid third millennium BC, three or four tier settlement hierarchies are in evidence, although these appear to show rapid restructuring every few centuries (Stein and Wattenmaker 1990; Wilkinson and Tucker 1995). Elite sectors of society are also evident from the appearance of high status graves, often within or adjacent to the settlements (Porter 2002; Schwartz et al. 2006; Akkermans and Schwartz 2003, p. 233; Stein 2004, p. 72; Zettler 1997, pp. 51-72).

The social context of urbanization can be inferred from both the settlements themselves and, for the third millennium BC, from cuneiform texts. During the late fifth and the fourth millennium BC (LC 1-2 and 3-4), for example, Tell Brak was surrounded by a cluster of smaller satellite communities that extended to at least $1 \mathrm{~km}$ from the edge of the main mound (Ur et al. 2011, fig. 3). On the other hand, in the Early Bronze Age most settlements formed distinctly bounded and nucleated communities, surrounded by cultivated areas that, in general, lacked minor settlements in the immediate vicinity (Wilkinson 2003, pp. 108-122). This nucleation implies that the social and political conditions favoured the grouping together of communities into some form of corporate structure (Philip 2008; Chesson 2003; Wilkinson 2010). Evidence of such a corporate structure can be inferred from textual records from early second millennium BC Mari, which suggest that many communities were administered under a group of elders, or a local king, or perhaps both (Fleming 2004, pp. 190-191). Whether this Middle Bronze Age model also operated for the EBA is unclear, but other texts from northern Syria suggest that the settlement and the surrounding lands were held as a unit, and that sometimes kings actually exchanged sites and their lands, which went together as an indivisible unit (Schloen 2001; Wilkinson 2010). In addition to their economic power, members of the royal household made ritual journeys that cemented their political authority and, in turn, enabled the economic wheels to turn (Ristvet 2011, p. 3; Jans and Bretschneider 1998, p. 156).

For the southern Levant in the late fourth and early third millennium BC, significant changes in the perceived value of agricultural products and intensification of production appear to have been associated with revised relations to that land (Philip 2003). That this process is broadly contemporaneous with the first well-dated fortifications in the area in the final centuries of the fourth millennium BC (Bourke et al. 2009) is probably not fortuitous. 


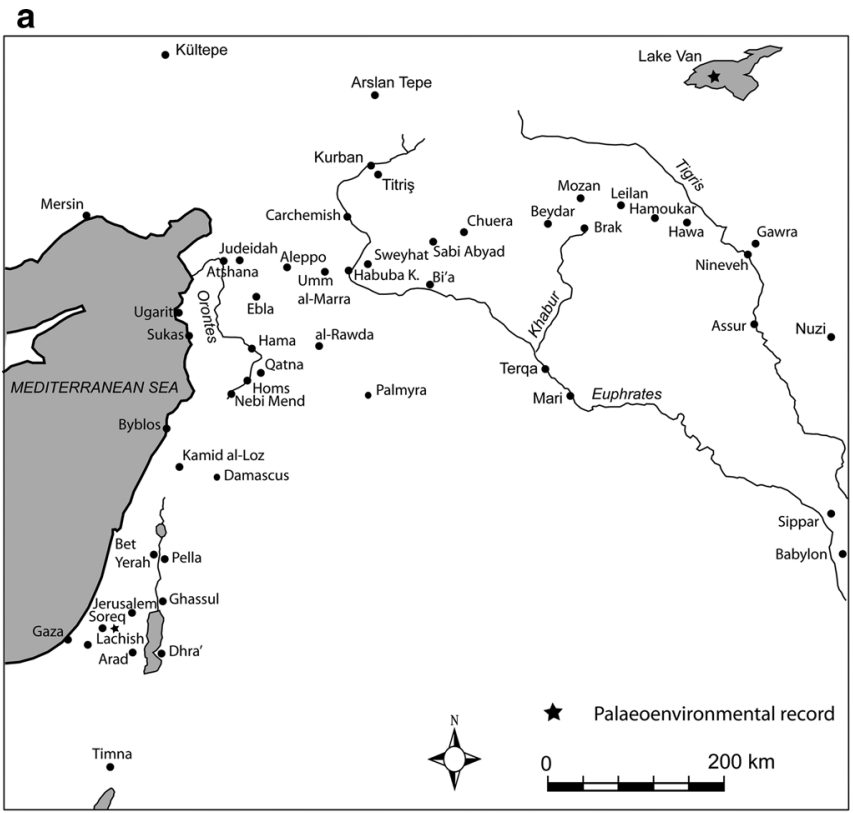

b

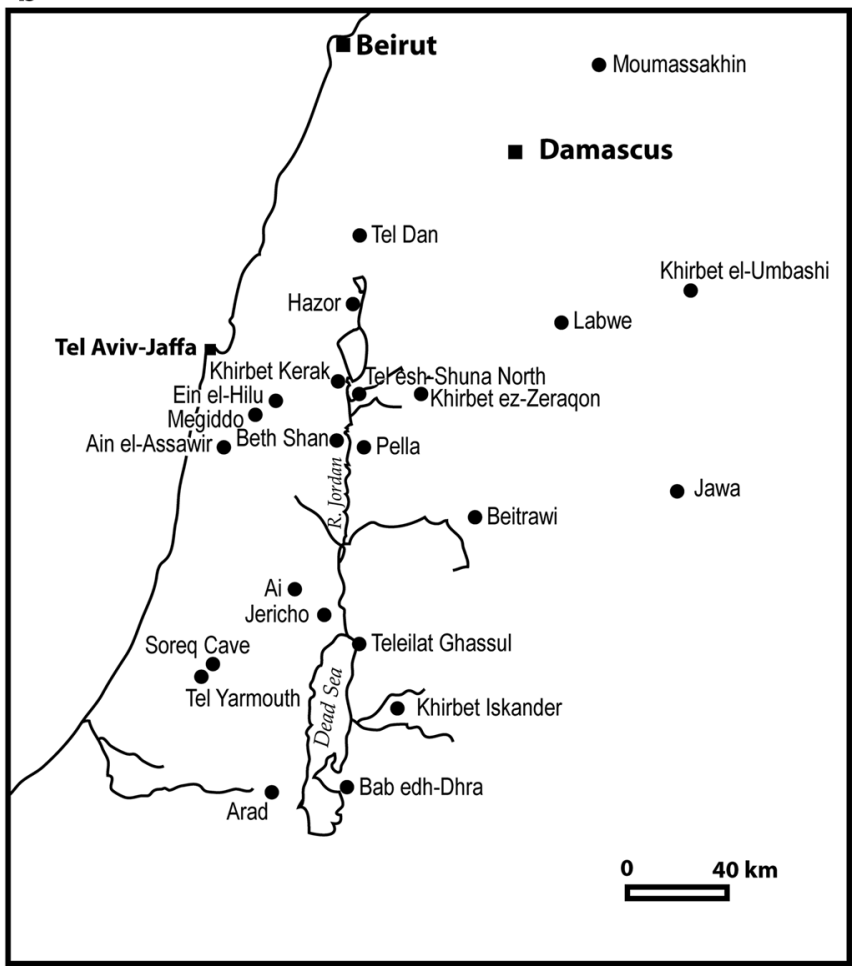


Similarly, connections to the land marked by monuments may also have contributed new ways of cementing relations to that land and affirming continuing rights of access, especially in areas in which permanent settlements were few. Continued access would have been of particular importance in a situation in which control of land was increasingly contested (Bradbury and Philip 2011, p. 176).

\section{The Key Landscape Categories}

Before discussing the results from specific archaeological surveys, we lay out the broad elements of the physical landscape that structured the development of the economies of the fourth and third millennia BC. Whereas in the Mediterranean the microecologies were a conspicuous element in the development of the way of life, such infinitely complex local landscapes (Horden and Purcell 2000, pp. 53-54) are less evident in much of the northern Fertile Crescent. Nevertheless, they are evident to the careful observer, and the territory of every EBA city comprised minor sub-regions-basalt plateaus, salt flats, relict marshes, flood plain and uplands - which not only supplied a diversity of opportunities and domains, but also formed a mosaic of inter-connected ecologies.

Within this framework of broad landscape units and diversified ecologies, EBA agricultural production can be classified into the following sectors (Wilkinson 2000b; Stein 2004, p. 67), each of which offered rather different possibilities according to the local landscape category:

1. The staple economy, particularly dry-farming of wheat, barley and lentils.

2. Production of olives and grapes in the wetter north and west, and the upland regions of the southern Levant.

3. Animal husbandry, including draft animals, pigs and, increasingly, sheep and goat herding. The last-named allowed for the growth in production of textiles from local wool.

In addition, the production of metal goods from copper, and overland trade, contributed to the growing strength of the palatial economies (Stein 2004, p. 67).

\section{Agricultural Plains}

The great agricultural plains and rolling hills of the northern Fertile Crescent, which stretch from northern Mesopotamia through to western Syria, appear to have formed the 'bread basket' of the region (Fig. 2). Although they receive only a modicum of rainfall, their large area compensated for the relatively low yields, allowing large aggregate production that rivalled that of southern Mesopotamia (Weiss 1986). These lowlands, which range from $800 \mathrm{~km}^{2}$ (Amuq) to some 7,000 km² (upper Khabur plains: Fig. 2), form a classic 'landscape of tells', and are associated with the 'staple economy' of cereal production described above. These semi-arid plains are dissected by smaller valleys, some of which, such as the Jaghjagh near Brak, during the mid fourth millennium BC, were remarkably verdant with a rich riverine vegetation of Populus (poplar) and Salix (willow), alongside slow flowing cool waters (Riehl 2011, p. 104). Although alluviation is limited across much of their extent, the flood plains themselves show significant but varying degrees of sedimentation, resulting in localized burial of settlements (Kuzucuoğlu et al. 2004; Casana and Wilkinson 2005; Deckers 2011; Deckers and Riehl 2007). 


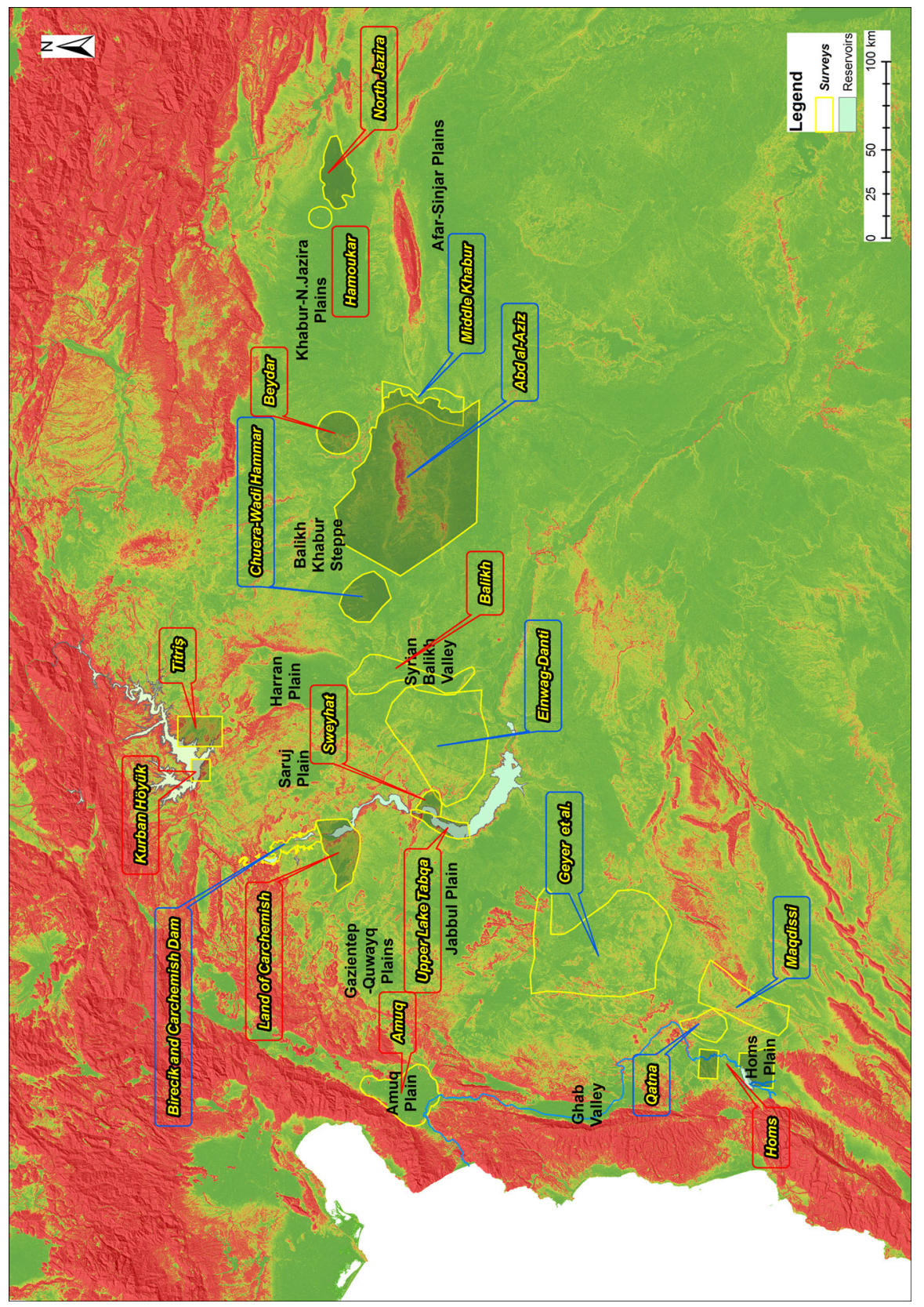

Fig. 2 Core agricultural lowlands as defined by slopes derived from SRTM imagery and key archaeological surveys (in yellow outline). The FCP survey areas referred to in text are shaded (Color figure online)

These extensive fertile plains are ideally suited for rain-fed cultivation, and although capable of massive aggregate production of cereals, are also susceptible to large scale crop failures due to periodic drought (Jas 2000, pp. 250-251). The largest of these plains is 
centred on the upper Khabur drainage basin and spreads well beyond the headwaters of the Khabur in Syria into southern Turkey and northwestern Iraq (Fig. 2), to form one of the key loci of early urbanism. It is flanked by the Taurus Mountains and Tur Abd-Din mountains to the north and the Jebels Abd al-Aziz and Sinjar to the south; soil, hydrological and geological conditions are summarized in Weiss (1986); Wilkinson and Tucker (1995); Ur (2010b); and Wilkinson (2003).

For this study, the agricultural lowlands are expediently defined by slopes created from Digital Elevation Models (Fig. 2), aided by the vegetation signature of crop lands on LANDSAT images and the distinctive pattern of fields on flat alluvial soils. These plains have been densely populated since at least the Aceramic Neolithic (Wilkinson 2003, pp. 100-123). Although only sample areas have been surveyed in the field, much broader areas have been mapped using remote sensing (Menze and Ur 2012; Deckers and Riehl 2008), demonstrating both the extent and the continuity of the tell-based landscape. The Tell Beydar and North Jazira surveys (NJS) provide exemplars (Case 1).

Additional agricultural plains include the upland plains west of the Euphrates, specifically the Gazientep/Quwayq upland plains (Wilkinson 2007); the Jabbul plain to the east of Aleppo; agricultural plains of the Harran/Balikh and Saruj; the Amuq, Orontes and Ghab valleys; and the western parts of the marl and limestone landscapes east of the Orontes (Fig. 2).

\section{Alluvial Valleys}

The valleys of the Tigris, Euphrates, Orontes, and Afrin Rivers and their tributaries have been eroded through Tertiary and Cretaceous limestone with occasional igneous rocks and are in-filled with deep alluvial sediments flanked by Pleistocene terraces (Bridgland et al. 2012; Demir et al. 2008; Wilkinson 1999). The fragmented landscapes drained by these riverine corridors provide smaller-scale landscapes of tells with more muted hierarchies than the extensive agricultural plains. Particularly common are small tells (1-3 ha), which dominate these cultural landscapes from the LC onwards (Schwartz and Falconer 1994; Philip 2007; Casana 2007; Schwartz et al. 2000; Wilkinson et al. 2012). However, where the valleys open up, or are flanked by broader plains, Bronze Age cities attained some 50-60 ha in area. This landscape type is represented by case studies from the Middle Euphrates Valley and the Homs area (Cases 3 and 4, below).

\section{Uplands}

In contrast to the agricultural plains and alluvial valleys, where the main medium of construction was mud-brick, the inhabitants of the uplands also employed stone and sometimes wood. The resultant low rubbly mounds and enclosures are less conspicuous than the tells and are sometimes associated with the place names khirba or rujm: these can be elusive archaeologically.

The mountains of western Syria and southern Turkey, which include limestone uplands and basalt plateaus, constitute a large, relatively under-explored area in which the extent of Chalcolithic and Bronze Age settlement is little known (but see Casana and Wilkinson 2005). Elsewhere, hill masses such as the Jebel Bishri and the plateau basalts west of Homs feature an archaeological landscape dominated by burial cairns and stone enclosures (Nakano and Ishida 2010; Lönnqvist 2010; Bradbury and Philip 2011). Philip and Bradbury (2010, p. 138) apply the term 'sub-optimal' to regions that, although by no means prime agricultural land, can offer considerable economic potential under certain 
circumstances. A case in point is the stony basalt terrain west of Homs, an area that was settled episodically and provides insights into the role of terrain beyond the alluvial corridors and plains (Case 4; Philip and Bradbury 2010).

\section{Climatically Marginal Lands}

Less distinctive geographically are extensive semi-arid plains such as those between the Balikh and Khabur Rivers, including the plains around Tell Chuera and the Jebel Abd alAziz (Case 2, below). Although these relatively unforgiving lands seem to offer little potential for cultivation, they do supply extensive areas of grazing, which in the twentieth century AD were progressively turned over to high-risk barley cultivation (Lewis 1987). During the third millennium BC these plains were extensively settled by the occupants of Kranzhügel mounds and citadel cities. Here citadel cities are regarded as consisting of a central citadel mound based upon an earlier tell, surrounded by a walled or ramparted lower town; they differ from Kranzhügel sites, which have ramparts and inner mounds that are circular. The plains of central Syria to the east of Homs and Hama have a similar history to those of the Balikh-Khabur plains, although settlement occurred somewhat later, between around 2400 and 2000 BC (EB IV: Geyer and Calvet 2001; al-Maqdissi 2010; Castel and Peltenburg 2007). This region shows clear evidence for horizontal fluctuations in the limits of settlement through time as well as the careful management of seasonal water sources (Geyer and Calvet 2001; Geyer et al. 2006; Geyer 2009).

\section{The Zone of Uncertainty and Ecologies of Risk}

\section{The Zone of Uncertainty Defined}

The above physical landscape types are cut across by a series of climate zones, which range from a belt receiving roughly $600 \mathrm{~mm}$ rainfall per annum in the north and west, to a semi-arid zone in the south and east which receives less than $200 \mathrm{~mm}$ (Fig. 3). As a result, the landscape offers several zones of rather different affordance. Insight into the way in which this landscape was utilized in the past can be gained from both historic and contemporary accounts (Lewis 1987; Jas 2000; van Driel 2000; Wilkinson 2000b). Such sources indicate that the moister belt featured a diversified land-use of wheat/barley and lentils with vineyards (and in western Syria, olives), whereas the dry zone to the east and southeast has traditionally been given over to semi-arid pasture dominated by nomadic and semi-nomadic pastoralists, superseded in more recent times by barley mono-cropping (Cocks 1988; Wilkinson 2000b). Where mean annual rainfall exceeds $300 \mathrm{~mm}$, local village flocks can be grazed on the village lands or taken to nearby sub-optimal areas as parts of a simple seasonal round (Philip and Bradbury 2010). On the other hand, in the semi-arid climatically marginal belt pasture lands are more extensive and flocks can range more widely.

Within the zone of marginal cultivation, that is, between the rainfall isohyets of c. 300 and 200/180 mm per annum, and where rainfall is erratic, cereal cultivation is much riskier and agro-pastoral practices have been the norm in recent times (Wachholtz 1996, pp. 5-8; Kalayc1 2013). This is the area defined here as the zone of uncertainty, and today, because of the high risk of crop failure, this zone is used primarily for a closely integrated system of sheep and goat husbandry with rain-fed cereals (Wachholtz 1996, pp. 5-9). As Wirth has pointed out, there is no clear-cut limit to rain-fed cultivation; rather, as the mean annual 

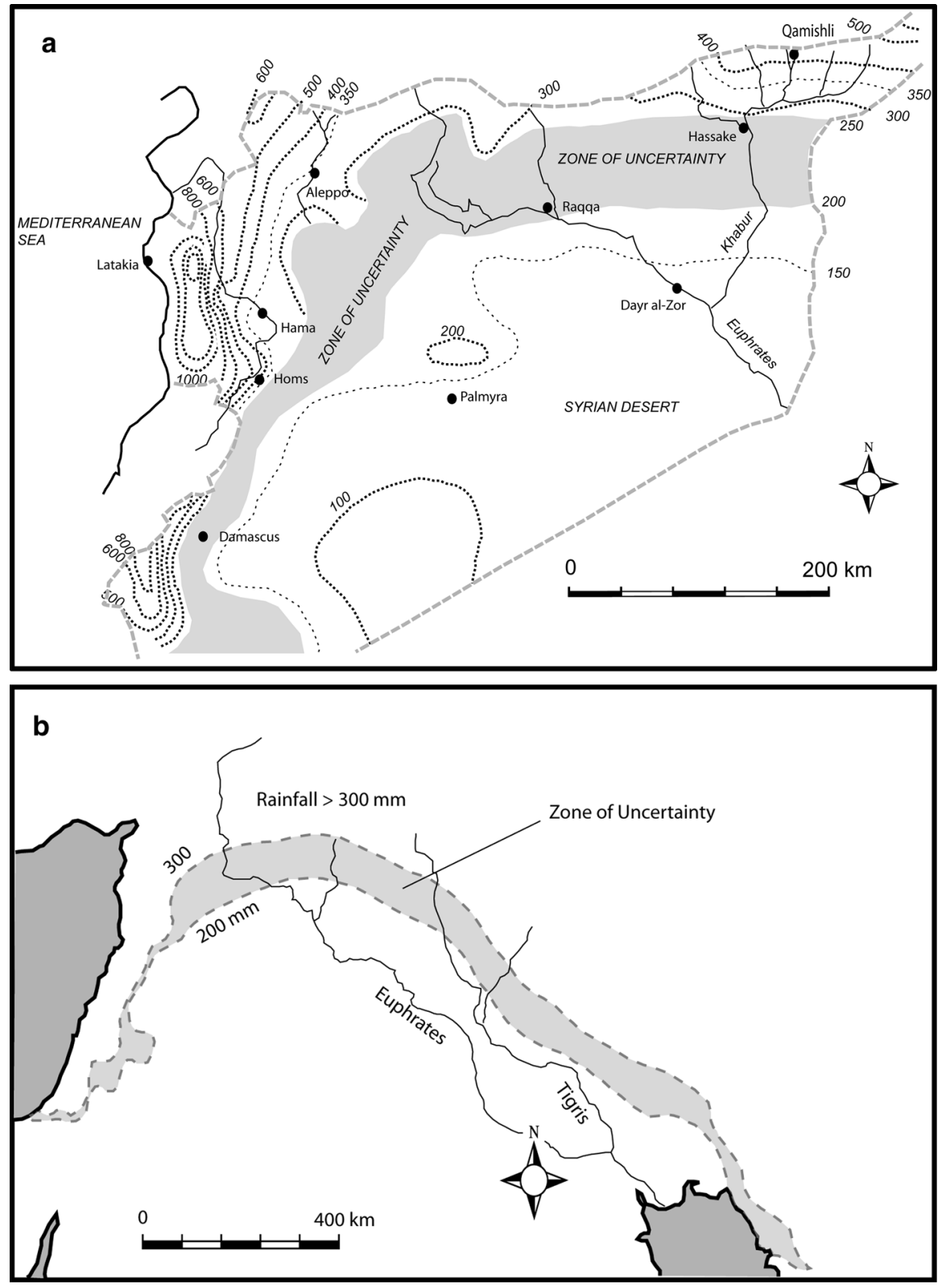

Fig. 3 a The zone of uncertainty within Syria (based on Wachholtz 1996). Dotted lines indicate rainfall isohyets; b the entire Fertile Crescent indicating the area with mean annual rainfall between 200 and $300 \mathrm{~mm}$ p.a. used as a proxy for the zone of uncertainty (simplified from Sanlaville 2000, fig. 21)

rainfall decreases the risk of crop failure increases (Wirth 1971; Jas 2000, pp. 250-257). Consequently, agro-pastoral practices must deal with high levels of uncertainty and incorporate considerable degrees of risk. 
Agro-pastoral Developments in the Syrian Steppe

In the twentieth century AD, central Syria experienced the expansion of both barley and sheep husbandry (Treacher 2000, p. 190; Cooper and Bailey 1990). As sheep production has become more dependent on fodder inputs from agricultural areas, farmers in these areas have responded by substituting barley for other crops as well as opening up more fallowed land. Flock owners have greatly extended barley growing into semi-arid rangelands, even into areas where rainfall is $<200 \mathrm{~mm}$ (Treacher 2000, p. 191), which is 'both the result of and concomitant with an intensification of sheep-rearing and an increase in flock sizes' (Métral 2000, p. 123). In other words, in these climatically marginal lands, increased sheep rearing and increased cultivation appear to have been closely correlated, ultimately supporting an increase in the human population, much of it sedentary or semisedentary.

Such economic growth in a zone that is today extremely marginal in terms of 'normal' agricultural subsistence is accompanied by a wide range of risks, which are played with considerable acumen by the local population (Métral 2000). Moreover, greater risk by farmers and herders is considered to lead to higher average returns (Hazell et al. 2001, p. 16).

In studies of the ancient world, risk is usually seen from the perspective of subsistence societies and as something that would have been minimized. Strategies such as diversification of crop types or intensification (including irrigation) are regarded as ways of reducing risk (Marston 2011, p. 191). However, this approach is not appropriate for Bronze Age states in the Near East, such as Ebla, that were benefiting economically from large-scale manufacture of textiles, metal trading and other activities (Pettinato 1981, pp. 166-167; Bachhuber 2013, p. 500), and can hardly be regarded as subsistence economies. Furthermore, this was a period in which aggressive states showed evidence for growth to such a degree as to suggest that they controlled a much wider range of physical landscapes and resources, which not only increased economic opportunities but also made the risk-benefit equation radically different from that which pertained in more self-sufficient communities. As a result of such shifts, the king, his household and other members of the elite had the ability to balance risk in one area against more predictable outcomes in another, and so had the potential capacity to invest in strategies such as large-scale sheep husbandry that resulted in huge profits, but also could lead to substantial losses (see below).

\section{The Plant and Animal Economy}

Animal bones recovered from excavated sites suggest that most Early Bronze Age communities in the moister north and west pursued relatively low-risk subsistence strategies of sheep/goat husbandry (the examples in this study being from the mid Euphrates Valley, below). However, these strategies changed through the third millennium BC, and Stein demonstrates that zooarchaeological evidence from sites in the Euphrates valley and North Mesopotamia show that in the mid third millennium BC the sedentary pastoral economy shifted from diversified herding of cattle, pigs, sheep and goats to a highly specialized economy dominated by sheep and goats (Stein 2004, p. 70; Zeder 1995, p. 29). For example, in the Khabur, mid-late EBA (2600-2000 BC) animal husbandry was dominated by sheep and goat, pigs, and significant numbers of cattle used for traction (Doll 2010, fig. 5). Analysis of multiple sites throughout the Khabur region by Zeder suggests a trend towards increased keeping of caprines in the third and second millennia BC, specifically in the southern steppe of the Khabur Valley (Zeder 1998, tables 1-4; see also Rufolo 2011). 
However, trends in the moister north, where rainfall exceeds $300 \mathrm{~mm}$ per annum, are less clear. At Mozan, caprines form between one half and two-thirds of the animal assemblages (Doll 2010, table 5), and at Brak they appear to decline in importance between the fourth and second millennium BC (Dobney et al. 2003, p. 428). Evidence that the caprines were used for supplying wool derives from the faunal samples from Tell Mozan in the north, where the lack of butchery marks on bones might be explained by the rearing of sheep for wool production (Doll 2010, p. 280), and at Brak age at death data suggest that animals were kept for their secondary products, probably wool (Dobney et al. 2003, p. 428). Zeder has therefore argued that the increase in caprines in the steppe of the southern Khabur indicates the development of an animal economy by pastoral specialists (Zeder 1998, p. 64). These enhanced herd management practices, which were first evident at Uruk sites of the later fourth millennium BC (Algaze 2008, pp. 77-92), are consistent with the socalled commodification of textile production associated with many third millennium states in the region (Stein 2004, p. 70; Kouchoukos 1998; McCorriston 1997; Zeder 2003; Porter 2012, pp. 19-21).

Although many smaller scale communities of the northern Middle Euphrates were engaged in a diversified economy, there was considerable variation depending upon local ecology or the scale of settlements. For example, at Gritille on the Turkish Euphrates, all age groups of sheep and goat were present, implying a relatively self-sufficient community (Stein 1987). This compares with the nearby and slightly larger site of Kurban Höyük, where the low percentage of prime age caprines during the main phase of mid-EBA settlement is interpreted as resulting from a system in which small towns such as Kurban supplied prime animals as tribute to growing centres (Wattenmaker 1998, p. 184). At the apex of this system, Titriş Höyük was arguably a centre of power and food distribution (Algaze et al. 2001; Allentuck 2004; Hald 2010). Broader regional trends are also evident, with sites in the Turkish Euphrates region showing a spread of domestic sheep, goat, pig and cattle, whereas southern sites like Sweyhat in Syria were characterized by a predominance of sheep and goat, fewer cattle, virtually no pig and many more wild species (Weber 1997, p. 142). Whereas increased sheep and goat appear to typify the zone of uncertainty, the belt of sustained settlement further north is approximately delimited by the southern limit of significant numbers of pigs (i.e. the $300 \mathrm{~mm}$ isohyet). While this is particularly evident for the fifth and fourth millennia BC (Grigson 2007, figs. 5.1 and 5.2), during the third millennium BC, very low proportions of pigs appear at citadel cities, many located within the zone of uncertainty (Grigson 2007, figs 5.4 and 5.6). In short, the distinction between areas with high proportions of pig and those with high proportions of caprines provides a rough guide to the northern boundary of the zone of uncertainty.

These tendencies are paralleled in the palaeobotanical record of the Middle Euphrates, with barley being less common in the north and dominant in the south (Miller 1997; Weber 1997; Riehl 2010, p. 68). Similar patterns are evident within the Khabur plains, where McCorriston and Weisberg demonstrate that there was a clear increase in barley in the southern Khabur steppe during the third millennium BC, for example (McCorriston and Weisberg 2002, pp. 493-495; Riehl 2010). Rainfall differences between the moister northern drainage basin and locations to the south are reflected in different proportions of crops, with higher proportions of free-threshing wheat at Mozan, to the north, and more barley at Brak in the south (Riehl 2010, p. 65; Riehl 2012, p. 117). Despite these regional variations, it appears that crop procurement strategies were quite resilient; for example, during the fourth millennium BC, although Tell Brak experienced several climatic fluctuations, the site's inhabitants adapted their strategies of crop production (Charles et al. 2010). Overall, the risk of crop failure increased towards the arid central area of Syria, so 
that, in theory, long-term sedentary settlement and its associated staple economies were more sustainable in the north and west.

However, communities, or perhaps the elites of such communities, within and around the zone of uncertainty, may have perceived the land less as a resource to be nurtured and more as an opportunity. This is in part because different communities may have different perceptions of risk. Therefore instead of using the landscape of the zone of uncertainty to produce a diversified range of staple crops and livestock (for which it was not really suited), they may have regarded it as ideal for agro-pastoral activity, specifically the 'opportunistic stocking' of sheep and goats. Such a herding strategy allows the number of livestock to increase in accordance with the availability of forage so that the growing herd can then be converted into 'capital' in years of good rainfall, whereas bad years can entail herd numbers being reduced as necessary (Sandford 1983; Stein 2005, p. 143). Such variations are a common feature of nomadic pastoral economies, which are inherently unstable (Khazanov 1984, pp. 75-83) and which have even been described as 'boom and bust' economies (Cribb 1991, p. 24). Similarly, West African examples see livestock numbers crashing during dry years with the result that range lands do not suffer from overgrazing (Mortimore 1998, pp. 66, 73; Behnke and Scoones 1993; Vetter 2005). In such non-equilibrium systems, pastoralists take advantage of the good times, but bear the loss during dry periods. Because episodic droughts can reduce stocking levels, or can encourage pastoralists to seek grazing elsewhere, instability can be regarded as an intrinsic part of this practice. For the Middle Euphrates, the southern areas within the zone of uncertainty, such as those around Tell es-Sweyhat, held the potential for great rewards, but presented significant levels of risk. This contrasts with the moister northern zone where more conservative strategies appear to have prevailed. Such challenges appear to have been acceptable for certain types of pastoral nomads, who have to accept higher levels of instability and therefore risk than many sedentary communities (Cribb 1991, p. 24). This may also have been the case for the aggrandizing polities of the Syrian plains, such as Ebla, which although largely sedentary were sufficiently prosperous to offset considerable losses from some areas of activity against successes in others. It is therefore significant that similar surplus-oriented strategies were harnessed to supply the non-food-producing temple and palace sectors of Mesopotamian cities (Stein 2005, p.147; Adams 2006).

In sum, when economies and states became sufficiently large in scale (as was arguably the case during the 'second urban revolution' of the EBA), elites or royal households could invest in animals and absorb risks in ways that more localized economies could not. Moreover, if yields were sufficient (in this case in the form of large quantities of high quality wool) and there were institutions which could absorb the risk (e.g. the Ebla palace), these otherwise marginal landscapes could become very productive. However, this will only work within a certain range of political-economic niches.

\section{Ebla and the Bronze Age Agro-pastoral Economy}

Ebla, located on the Syrian plains quite close to the western edge of the zone of uncertainty (Figs. 1, 17), occupies a central position in this narrative because, rather than simply being supported by cultivated cereals supplemented by flocks of sheep, goat or cattle, the Eblaite state was arguably founded, in part, upon an agro-pastoral economy. Ebla, the dominant capital city of northwestern Syria during the third quarter of the third millennium BC, ruled over a state extending from near Hama, or Homs [if the Très Long Mur (Geyer et al. 2010) 
is related to the Ebla state] in the southwest, to near Carchemish on the Euphrates in the northeast (Cooper 2010; Fig. 1).

It is well known that sheep-rearing formed a major pillar of the Eblaite economy (Gelb 1986, p. 158), although as argued by Porter, the quotation below may rather over-simplify a potentially complex system of animal herding (Porter 2012, p. 19):

Sheep raising was the mainstay of the local economy; thousands of sheep were raised, supplying the wool for the production of textiles, the main export product of Ebla. Thus wool was the basis of Ebla's commercial prosperity and political power ... But Ebla, as these extraordinary tablets make clear, was an empire built on the backs of simple shepherds. (Gelb 1986, p. 158)

It would appear from the archives of Palace $\mathrm{G}$ at Ebla that textile production was, at least in part, under the control of the palace, and the Ebla texts refer to the delivery of textiles (many specifically of wool) to individuals or cities, or their use as offerings to the gods (Sollberger 1986, p. 6; Biga 2010; Andersson et al. 2010, p. 160; Bachhuber 2013, p. 500). Estimates of the number of sheep held by the city of Ebla range from 2 million, according to Butz (cited by Pettinato 1991, p. 82) to a more modest 670,000, according to Milano (1995). At relatively modest rates of stocking of 4.5 ha per animal (McCorriston 1997, p. 524, after Thalen 1979, p. 265), it would appear that the entire state of Ebla might have formed sheep pasture, or agricultural lands devoted to producing feed for such sheep. Using the above stocking figures by way of indication, 700,000 sheep would have required a grazing range of around $31,500 \mathrm{~km}^{2}$ (roughly equivalent to a circle of radius $100 \mathrm{~km}$ ). This is a substantial area, even allowing for the possibility of grazing in agricultural land out of season, and would have required flocks to be grazed at locations some distance from the central territory of Ebla. Large flocks of sheep would have needed to be accommodated in the villages surrounding Ebla (Porter 2012, p. 19, citing Archi 1990), and, according to Milano (1995), pasturing would also have taken place in, for example, the Kur (hill country) to the north and south of the city, or, as noted by Castel and Peltenburg (2007, p. 613), around al-Rawda (and related cities) in the zone of uncertainty in the central Syrian steppe.

It is difficult to estimate the spatial extent of this sheep-rearing, but one area discussed here, the Sweyhat region, is close to the borders of the Eblaite state, and could have been a direct or indirect beneficiary of the state's herding strategies. Moreover, the Ebla texts indicate that large quantities of wool were purchased from Armi, which although not identified securely, may be at Tell Bazi-Banat on the Middle Euphrates (Biga 2010, pp. 149-150, 152, citing Otto 2006) or perhaps near Samsat to the northeast (Archi 2011). Because Armi appears to have been on one of the routes between Ebla and Tell Brak (Nagar) (Archi and Biga 2003, p. 13; Otto 2006, p. 21), large quantities of wool were being supplied to Ebla from a city/polity located on the route between Ebla and Nagar. In the same region, Harran is recorded as a source of sheep for Ebla, and Carchemish as both a source and recipient of textiles (Pettinato 1976, pp. 147-148; Pettinato 1981, p. 209; Bachhuber 2013, p. 500). In contrast, however, the Homs basalt, although a probable venue for small-scale pastoral activity, lacks convincing evidence for large-scale activity during EB IV (Philip and Bradbury 2010, p. 155), suggesting that certain localities or types of landscape, such as the steppe of central Syria, were favoured over others for large-scale livestock herding.

Although the actual numbers of livestock may have varied dramatically through time, the raising of sheep was evidently a major part of the Ebla economy, and the Eblaite administration would therefore have required access to large areas of steppe grazing. The appearance of such huge holdings of sheep must have formed part of 'a major transformation of ancient Mesopotamia' that entailed a shift from plant fibres, particularly flax, to 
wool for the manufacture of textiles during the third millennium BC, or slightly earlier (McCorriston 1997, p. 517; also Kouchoukos 1998; Zeder 2003, p. 162; Algaze 2008, p. 79; Porter 2012). However, the roots of such textile production extend back to probably the fifth millennium BC, as exemplified by the size of spindle whorls, which suggests that this transition occurred within the Chalcolithic (Sudo 2010, p. 176). The switch from flax to wool would have 'freed prime agricultural land for alternative crops, including presumably cereal crops' so that more fibre (i.e. wool) could have been raised on the 'vast tracts of marginal land using less labour than flax cultivation' (McCorriston 1997, p. 525). Certainly the scale of the wool industry of Ebla was extraordinary, and would not be matched until the Ur III state (Milano 1995). Although it appears that the use of sheep for wool has a long history in the Middle East, it is the scale of both the demand for, and production of, this highly desired product that became significant in the fourth millennium BC and, even more so, in the third millennium (Algaze 2008, pp. 77-92; Wright 2013, p. 397, pp. 407-410). It is therefore a central aim of this paper to examine the landscape evidence for this major economic transformation.

\section{Connectivity and Networks}

Evidence for changing degrees of 'connectivity' through time is both direct and indirect, as discussed for the Mediterranean by Horden and Purcell (2000). Here evidence of connectivity is only summarized and will be discussed in more detail in a future paper. For southern Mesopotamia, enhanced connectivity is evident in terms of the increased efficiency of canal and riverine transport, in contrast with 'high friction' overland transport (Algaze 2001, pp. 224-225; Algaze 2008, pp. 50-63; Wilkinson 2000b, p. 6). Although probably the most common way of inferring route systems in the ancient world is through topography, aided by 'least-cost' analysis (Witcher 1999), such approaches-as well as being somewhat deterministic_-are difficult to apply to topographically level plains. More problematically, cuneiform documents suggest that such physically 'logical' routes were frequently unfeasible because for sociopolitical reasons it was sometimes necessary for travelling 'officials' to carry particular documents to allow themselves free passage through certain areas (Wattenmaker 2009, p. 119). An analogous situation can be observed today where state control is weak and it is necessary (as well as courteous) when travelling through a region to visit each minor chief or ruler in turn, with the result that the actual route followed zigzags across the landscape between major settlements rather than following a straight line. In other words, social and political factors often outweigh the opportunities offered by the physical landscape.

In parts of northern Syria and northwestern Iraq, tangible evidence of early routes is provided by networks of hollow ways etched into the landscape by the passage of humans and their livestock (Van Liere and Lauffray 1954-1955; Wilkinson 1993; Wilkinson et al. 2010; Ur 2003, 2012; Casana 2013). The relationship between settlement and connectivity is eloquently demonstrated by some $6,025 \mathrm{~km}$ of hollow ways mapped over much of the upper Khabur plains (Ur 2010b, 2012). These features demonstrate that radial movements from central tells were mainly confined within local catchments of 3-5 km radius (Kalayc1 2013, pp. 149-171). Such local routes were probably more important than cross country hollow-way networks-which, although recognizable, are less pronounced and have left less evidence-in part because most overland movements were probably from one settlement to the next in order to conform with social norms as noted above (Ur 2012, pp. 172-175; Wilkinson and Tucker 1995, p. 54). 
In addition, paired settlements on opposite banks of major rivers (Burghardt 1959; Wilkinson et al. 2004) sometimes align with and link to routes leading away from such crossing points. Similarly, gaps through the Bronze Age Très Long Mur in the steppe east of Hama, imply the existence of passageways that concentrated the movement of humans and animals (Geyer et al. 2010). Alignments of Bronze Age tells that are independent of obvious topographic or hydrological features also suggest that sites had developed along pre-existing routes (e.g. Philip 2007).

Finally, inferences can be made from the human ecology of local landscapes or textual sources. In the former case, contemporary activity in neighbouring landscapes of contrasting geology or topography which show different archaeological signatures may imply that the two landscapes formed a semi-integrated system of land-use, for which we have no direct evidence (Philip and Bradbury 2010; Bradbury 2011). Connectivity is also evident in interpretations of ideational landscapes, specifically with respect to the 'round' of ritual visits made by members of the royal household to shrines and other venerated places, as mentioned in the Ebla texts (Ristvet 2011).

\section{Data Sources and Methods}

Survey Areas (Figs. 2, 4)

The archaeological survey data considered here has been compiled as part of the FCP and is derived from surveys conducted since the 1970s across the entire region from northwestern Iraq to the Orontes Valley in western Syria and southern Turkey (Galiatsatos et al. 2009; Fig. 4). From west to east these surveys are:

- The Homs Region Survey (Syria): directed by Graham Philip, Farid Jabbour and Michel al-Maqdissi since 1999 (Philip et al. 2002, 2005; Philip 2007; Philip and Bradbury 2010).

- The Amuq Survey (Turkey): initially conducted by Robert Braidwood (1937) in the 1930s, resurveyed from 1995 by a team from the Oriental Institute, Chicago (Casana and Wilkinson 2005).

- The Land of Carchemish Project (Syria): by teams from Durham and Edinburgh Universities (Wilkinson et al. 2007).

- The Tell Sweyhat Survey (Syria): conducted in 1974, 1991 and 1992 by a team from the Oriental Institute, Chicago (Wilkinson et al. 2004).

- The Kurban Höyük Survey (Turkey): conducted from 1980 to 1984 as part of the Oriental Institute (Chicago) Project at Kurban Höyük. Director Dr. Leon Marfoe (Wilkinson 1990).

- The Titriş Höyük Survey (Turkey): conducted in 1990 and 1992 as part of the Titriş Höyük Project (Algaze et al. 1992, 2001; for the Euphrates surveys see also Wilkinson et al. 2012).

- The Balikh Valley Landscape Survey (Syria): conducted between 1993 and 1995 to complement an earlier survey directed by P.M.M.G. Akkermans (Akkermans 1993; Curvers 1991; Wilkinson 1998).

- The Tell Beydar Survey (Syria): conducted in 1997 and 1998 by a team from the Oriental Institute, Chicago (Wilkinson 2000a, Wilkinson 2000b; Ur and Wilkinson 2008; Nieuwenhuyse and Wilkinson 2008).

- The North Jazira Project (Iraq): conducted between 1986 and 1990 by the British School of Archaeology in Iraq (Wilkinson and Tucker 1995). 


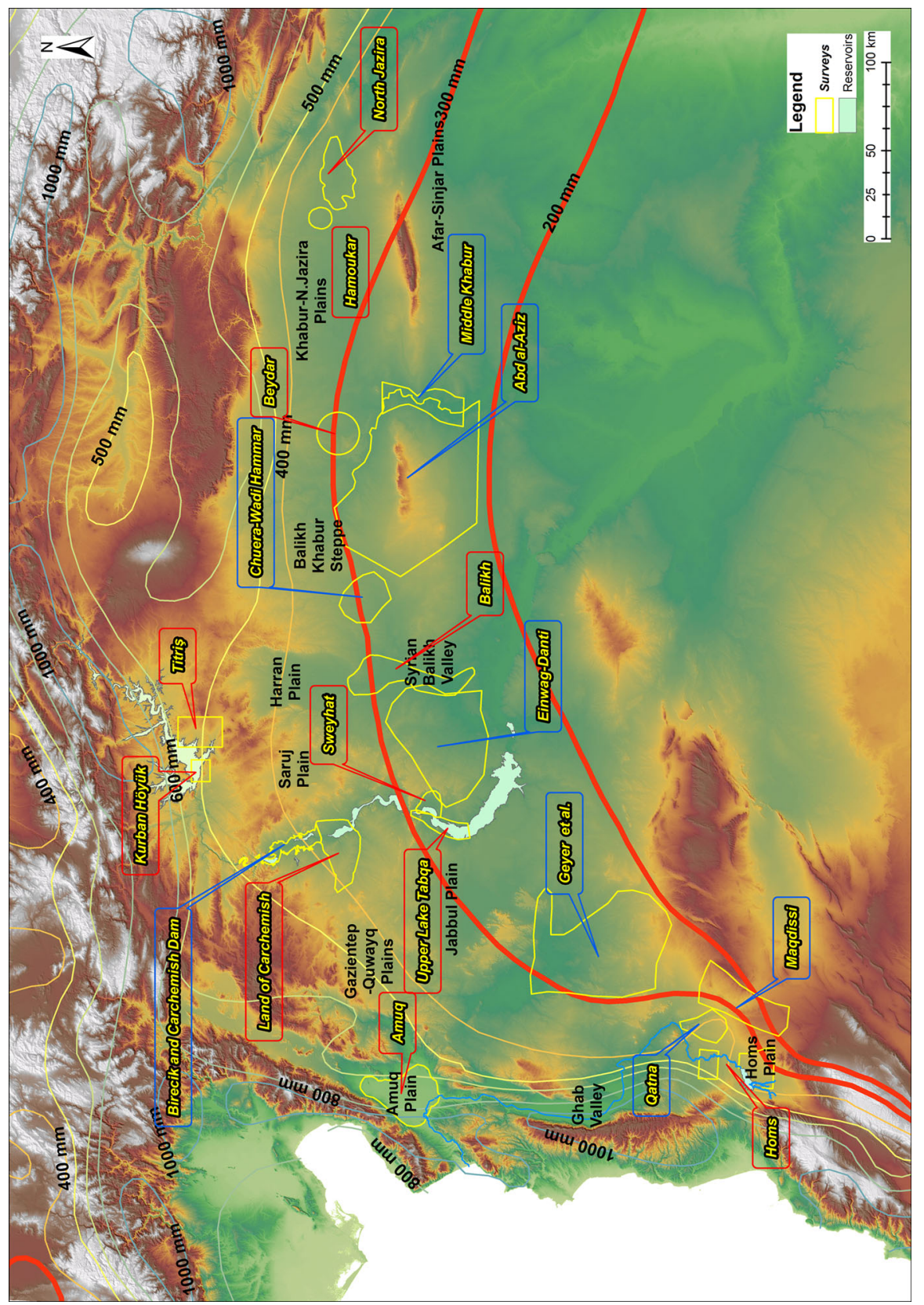

Fig. 4 Selected survey areas of the FCP and other surveys discussed. Zone of uncertainty indicated by thick red isoyhets (Color figure online)

The FCP team is reanalyzing the above 'legacy' surveys, checking descriptions and site dimensions, recalculating site areas, and, where necessary, employing satellite imagery to recognize features or sites missed during the original surveys (Lawrence 2012). The use of 'air truth' from satellite imagery enables us not only to strengthen the results of the original 


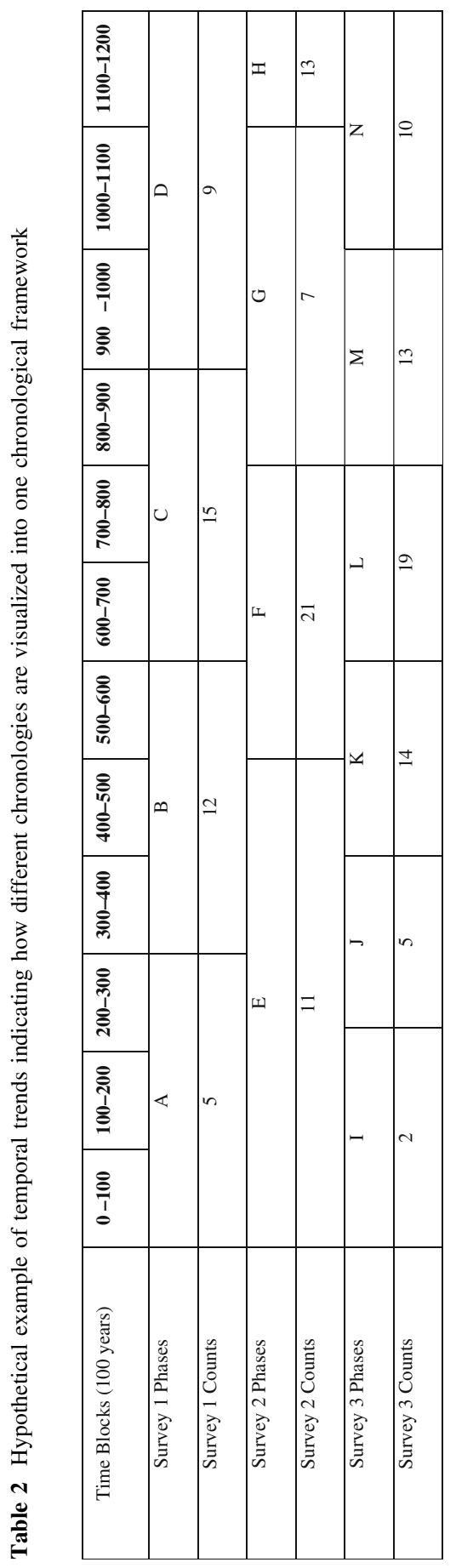


surveys, many of which were conducted without the benefit of aerial images, but also to encompass more meaningful areas, such as ancient polities or city regions.

Scale is fundamental to landscape archaeology because of the need to deal with individual sites and archaeological surveys that cover areas of variable size. In the case of the FCP, survey areas are located in several different countries and some even extend over international frontiers (Fig. 4). Multiple sources of satellite imagery of various ages and resolutions have also been included (Galiatsatos et al. 2009).

Comparison of data at the regional scale necessary to demonstrate settlement trends across the Fertile Crescent requires the integration of different surveys into a single chronological framework (Lawrence 2012; Lawrence et al. 2012). Differences in ceramic chronologies across this region preclude direct comparisons between individual phases, so that each of the FCP surveys divided the millennium-long EBA into between two and five phases, none of which are of the same length. The solution developed in the FCP, and employed here, is to use published chronologies to relate each phase to calendar dates in years (Lawrence 2012; Lawrence et al. 2012). By transforming the individual phases into a similar metric we can model trends in settlement in a way that allows for direct visual comparison between evidence from different surveys. The approach is best explained using example data. Table 2 provides site counts for three hypothetical surveys with very different chronological schemes.

The disparities in phase length render direct comparisons between individual phases problematic. However, by converting these phases into 'time blocks' of one hundred years each we can display the data in a way which allows the broader trends to emerge. Figure 5 shows the above survey data expressed in this way.

\section{Total Number of Sites in Surveys 1, 2 and 3 by 100-year time blocks for period 0-1200 AD}

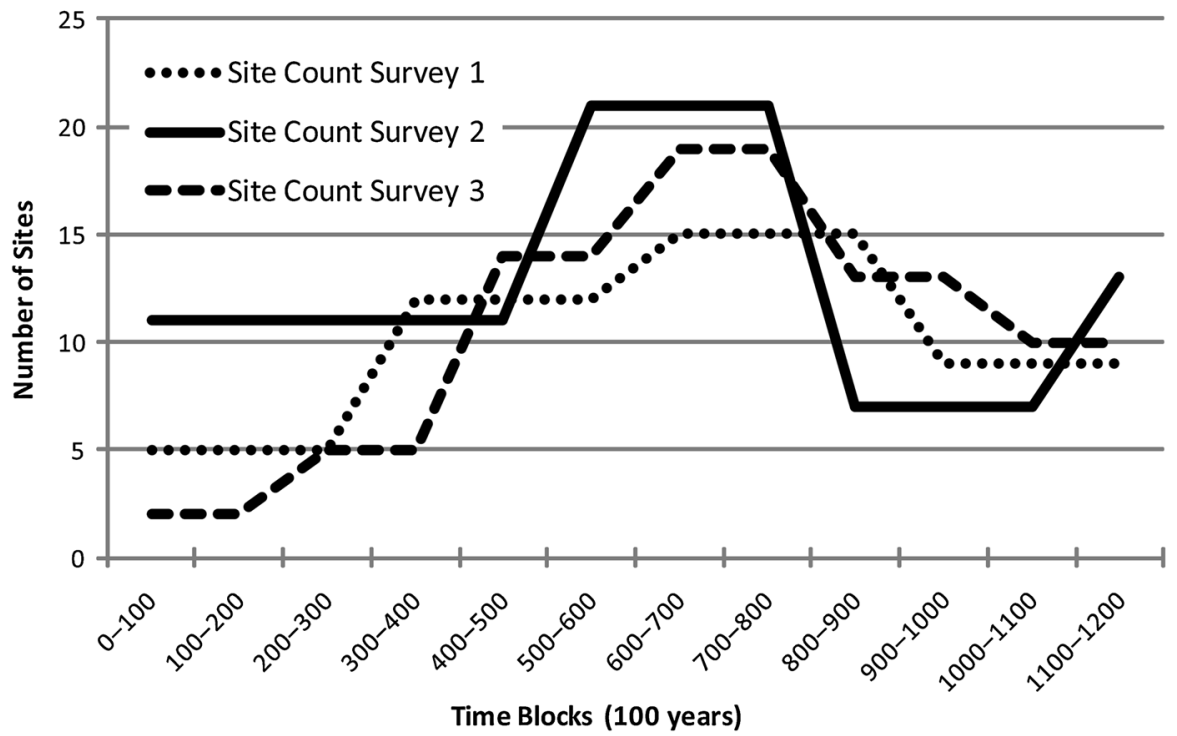

Fig. 5 Hypothetical example of temporal trends (derived from Table 2) indicating how different chronologies are visualized and combined into one chronological scheme 
Despite the chronological differences within the surveys there is clearly an overall trend of expansion and contraction of settlement over the 1,200-year period, and this trend would have been very hard to extract from the data as expressed in phases. The time-block graphs used in this article display total settled area by 100-year increments, reflecting the degree of precision currently available in the date attributions for each phase. Synthetic chronologies for western Syria along with those recently published for the Middle Euphrates (Porter 2007; Cooper 2006) and the Jazira (Lebeau 2000; Pfälzner 2001, 2010) provide the basis for these comparisons, coupled with limited re-evaluation of the ceramics from the surveys.

\section{Case Studies}

In the following case studies, the terminology of the chronological units follows those employed by the projects themselves: for example, the chronology of the Khabur-Balikh steppe follows the Early Jazira (EJ) chronology used by Kouchoukos (1998), rather than the more general chronology of Lebeau (2000) (Table 1). The chronologies of expansion and contraction of the major sites are those published by the excavators, and are expressed in centuries on Figs. 8, 10, 12, 13 and 16.

\section{Northwest Iraq and Northeast Syria (Figs. 6, 7, 8)}

In the northeastern part of North Mesopotamia a long-term pattern of dispersed villages evident from the Neolithic to the Late Chalcolithic culminated in the emergence of largescale urban centres during the fourth millennium BC. In the NJS, the early EBA Ninevite V period (c. 3000-2500 BC) sees a radical shift away from the relatively dense rural settlement pattern characteristic of the LC - dominated by the single mass of Tell al-Hawato the abandonment of the southern and western parts of the survey area (Figs. 6, 7). The three-level settlement hierarchy that developed in the east of the area was characteristic of the entire third and part of the second millennium BC. The opening up of the southern and western parts of the area has been interpreted as stemming from the reorganisation of settlement and land-use to provide pastureland (Wilkinson and Tucker 1995), but whether this was the result of a deliberate policy of opening the landscape or a by-product of settlement agglomeration is not clear.

However, abandonment of sites in the south and west was not associated with a significant decline in overall settlement. Instead, the time-block graphs (Fig. 8) demonstrate that although the total number of sites plummeted from over 70 to under 40 , the aggregate settled area remained fairly stable, because those sites that remained grew in size (Fig. 8). This implies that any populations released were incorporated into growing nucleated sites within the same region. Moreover, settlement expansion at both Hamoukar and Hawa appears to have been fuelled, in part, by the abandonment of smaller outlying sites, perhaps as populations were sucked into the growing centres (cf. Adams 1981). Roughly contemporary with the abandonment of the south and west, agricultural intensification occurred in the north and east of the region, as demonstrated by the presence of off-site sherd scatters and radial patterns of hollow ways around the larger sites (Wilkinson 1994, pp. 491-493; Ur 2010b, pp. 65-85). Over the course of the third millennium, settlement began to impinge on the abandoned zone but the area remained a discrete 'pastoral enclave' within the larger zone of dense settlement around urban centres at Tell al Hawa and Tell Hamoukar. The proximity of Hamoukar to this unsettled land implies that the open area may either have been a shared resource between the two centres, or perhaps 


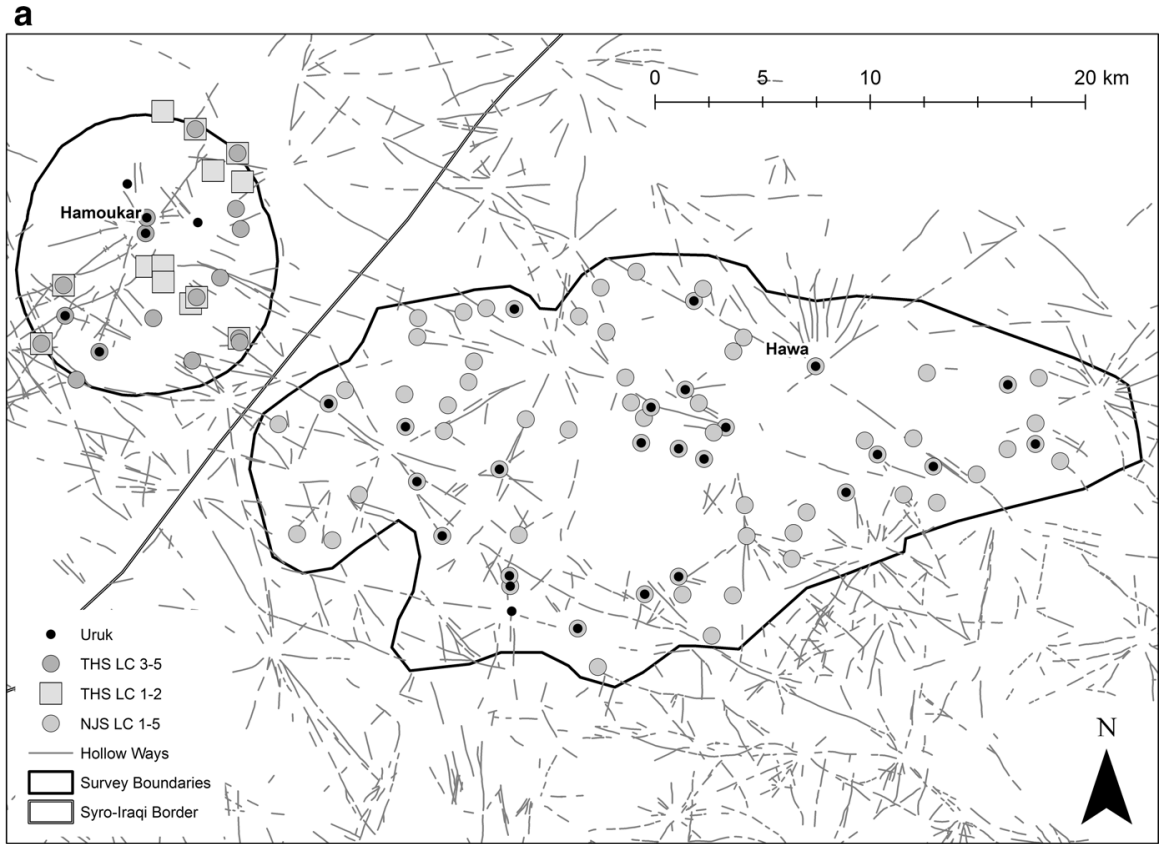

\section{b}

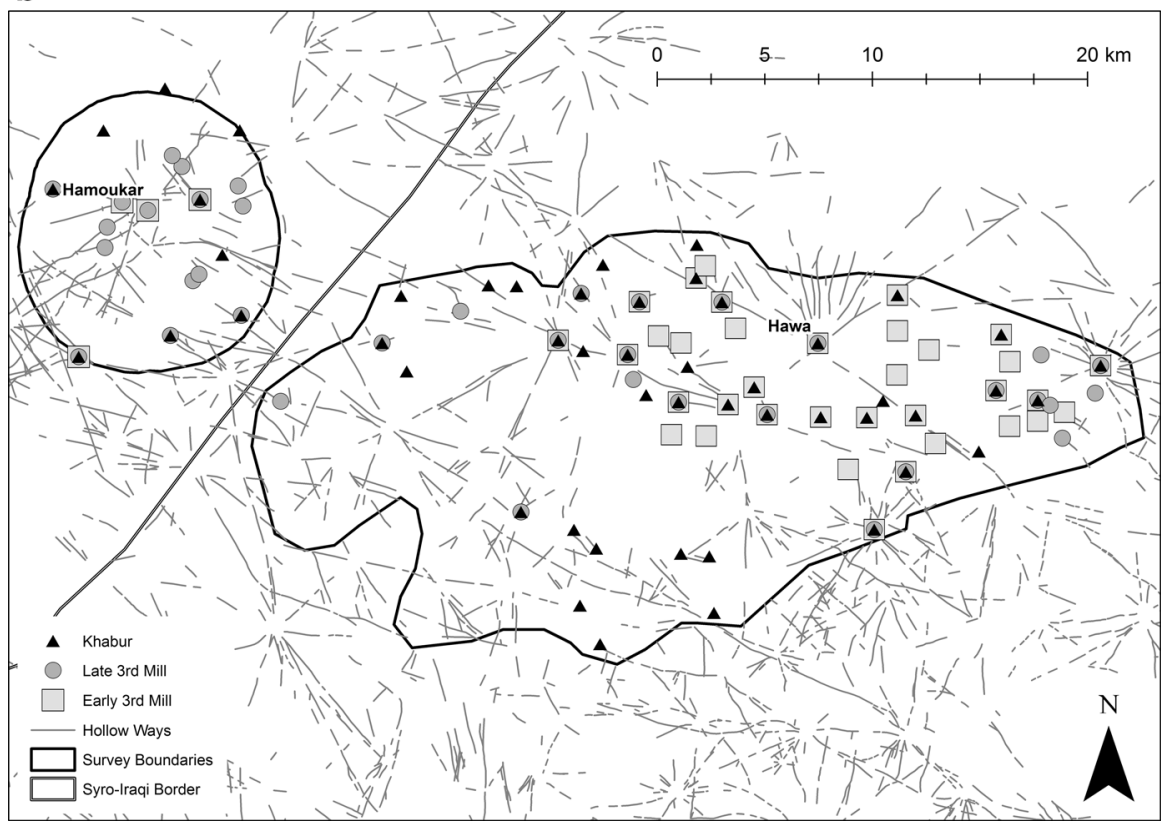

Fig. 6 (top) The North Jazira (NJS) and Hamoukar (THS) survey areas in the Late Chalcolithic (LC) period (after Wilkinson and Tucker 1995 and Ur 2010b); (below) the North Jazira and Hamoukar survey areas in the third millennium BC (after Wilkinson and Tucker 1995 and Ur 2010b) 


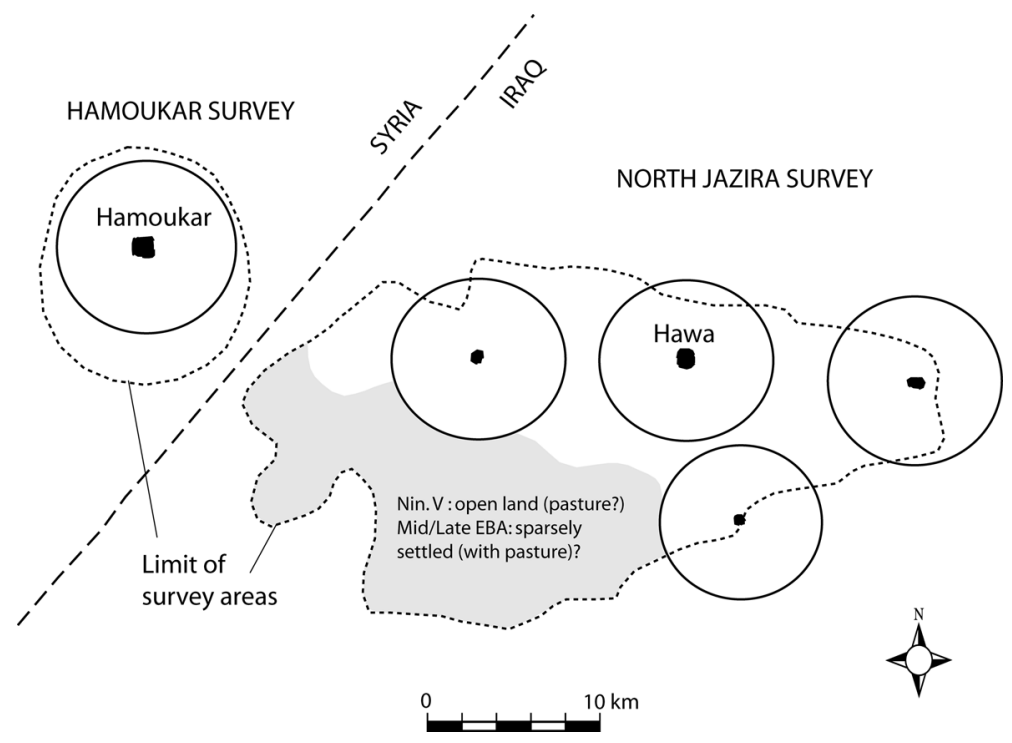

Fig. 7 The North Jazira and Hamoukar survey areas, showing the approximate area of potential pastureland as inferred from the retreat of settlement around 3000 BC (based on Wilkinson and Tucker 1995; Ur 2010b)

acted as a boundary between the two polities, depending on the phase (Fig. 7). In contrast to the expansion of settlement in the Middle Euphrates (below), settlement in the area of the North Jazira Project underwent a process of reorganisation which resulted in intensified agricultural production around urban centres and managed pastoral resources in close proximity.

The Khabur-Balikh Steppe (Figs. 9, 10)

The dry marginal steppe located between the Balikh and Khabur river systems, although forming a broad rolling plain, does not constitute one of the main agricultural 'core' areas as outlined above; rather, it is one of those areas into which settlement expanded during the third millennium BC. This region is known for the distinctive large sites, which belong either to the double-walled site type commonly referred to as Kranzhügel, or to a class of citadel cities typified by central tells and surrounding ramparts (Oppenheim 1964; Zettler 1997; Cooper 2006, pp. 74-78; Meyer 2010a). Also known as the Western Jazira, not only does this area present a unique settlement pattern from the fourth to the early second millennium BC, it is overwhelmingly situated in the agro-pastoral high-risk zone of uncertainty, between the 200 and $300 \mathrm{~mm}$ precipitation isohyets (Fig. 9). Archaeological investigations in this region have been scarce, yet those that have been conducted provide a picture of settlement processes that complements the picture from the core areas. Human occupation of the region is evident from the Palaeolithic onwards, mostly in the form of small, often temporary sites, with more permanent settlements forming in the Halaf and Ubaid periods. Yet this general, albeit slow, trend toward a greater number of larger and more complex sites came to a halt in the Late Chalcolithic period, when the overall number and individual sizes of settlements fell dramatically. Unlike the fertile river valleys to the 


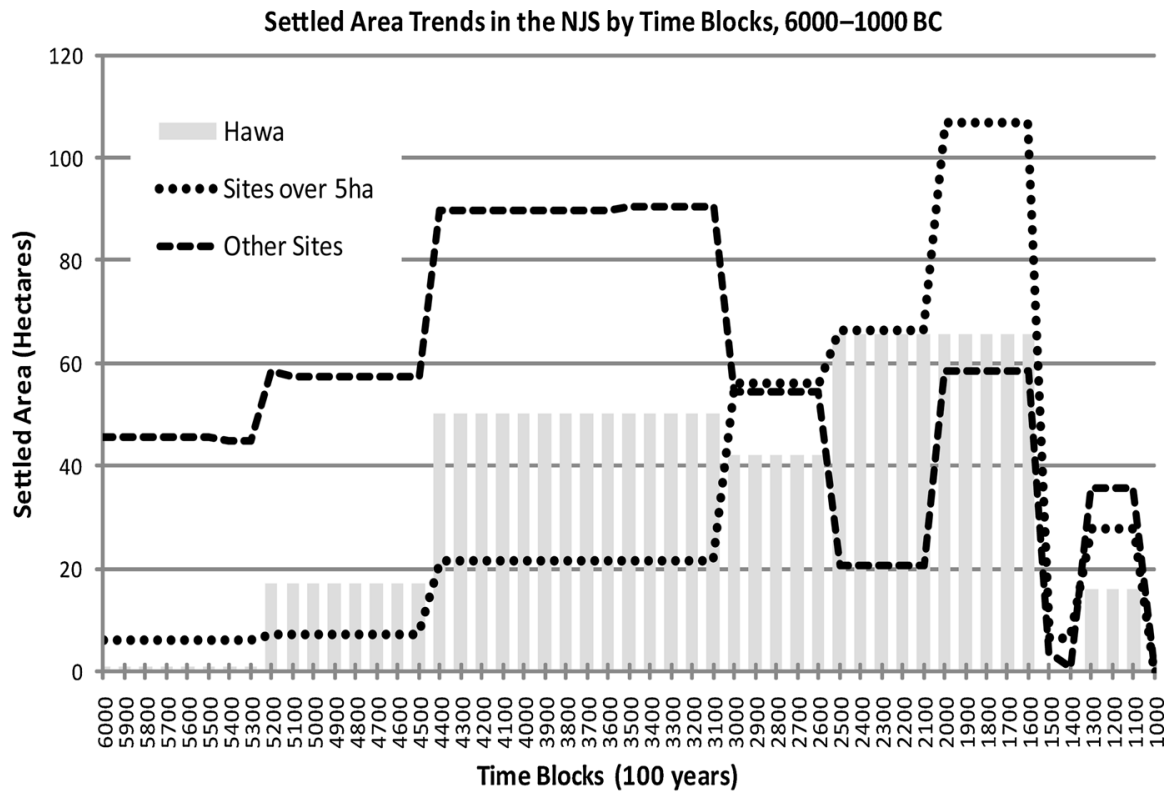

Site Counts in the NJS by Time Blocks, $6000-1000 \mathrm{BC}$

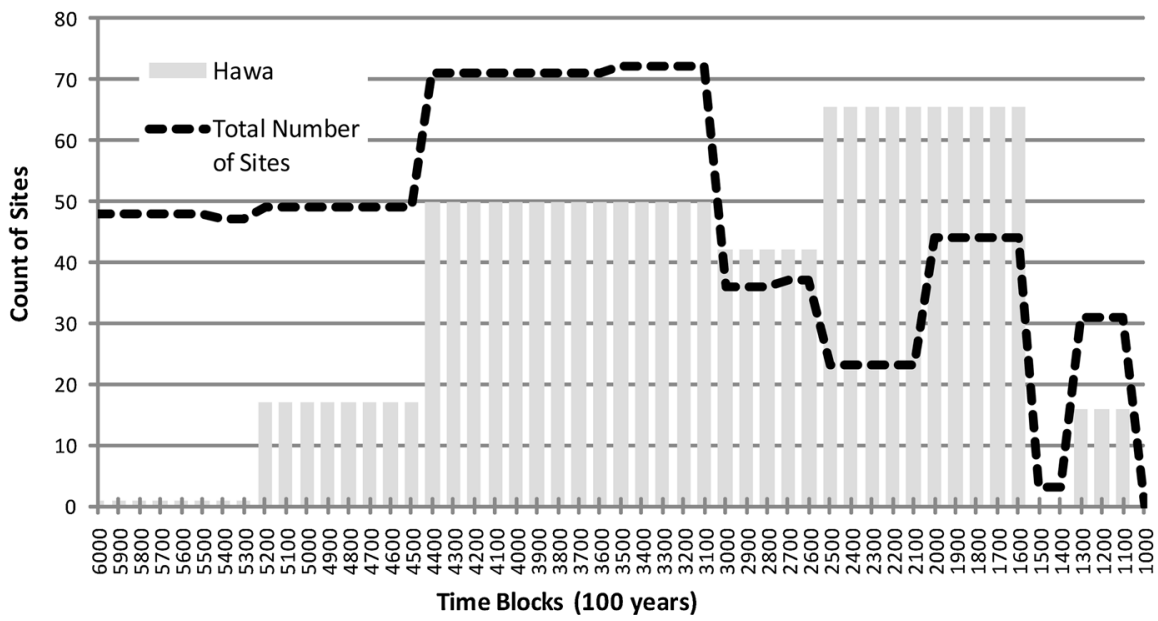

Fig. 8 North Jazira Survey (NJS) (Iraq); top settled area of Hawa, medium sites and small sites 6000-1000 BC; bottom settled area of Hawa, count of other sites 6000-1000BC. Note the significant decline in the number of sites around $3000 \mathrm{BC}$ as the western region was abandoned and Hawa developed into a nucleated town

east and west, the Western Jazira experienced a dearth of human occupation during the fourth millennium until the EJ 2 period (c. 2800-2650 BC, Table 1).

In the northwest of this region the Wadi Hamar survey, centred on the mainly third millennium site of Tell Kharab Sayyar, covers $680 \mathrm{~km}^{2}$. This survey identified 6 sites covering a total area of 18 ha (including the 7.5 ha Tell Tawila) from the Ubaid period, yet not a single definite small site from the succeeding Late Chalcolithic (Pruß 2005; Kudlek, 


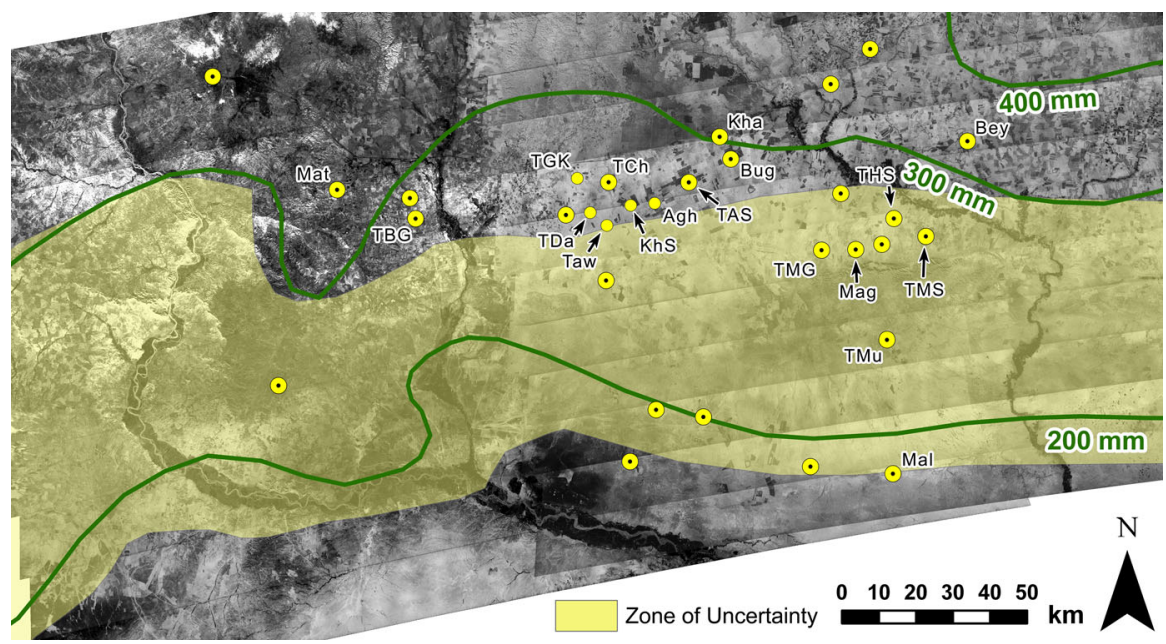

Fig. 9 Main sites discussed in the Khabur-Balikh steppe (rainfall isohyets in mm per annum). TAS Tell Abu Shakhat, Agh 'Aghila, TBG Tell Barabra Gharbi, Bey Tell Beydar, Bug Tell Buga, TCh Tell Chuera, TDa Tell Dakhliz, TGK Tell Ghajar el-Kebir, THS Tell Hammam Sharqi, Kha Tell Khanzir, KhS Tell Kharab Sayyar, TMG Tell Mabtuh Gharbi, TMS Tell Mabtuh Sharqi, Mag Tell el-Maghar, Mal Tell Malhat, Mat Tell Matin, TMu Tell Muazzar, Taw Tell Tawila

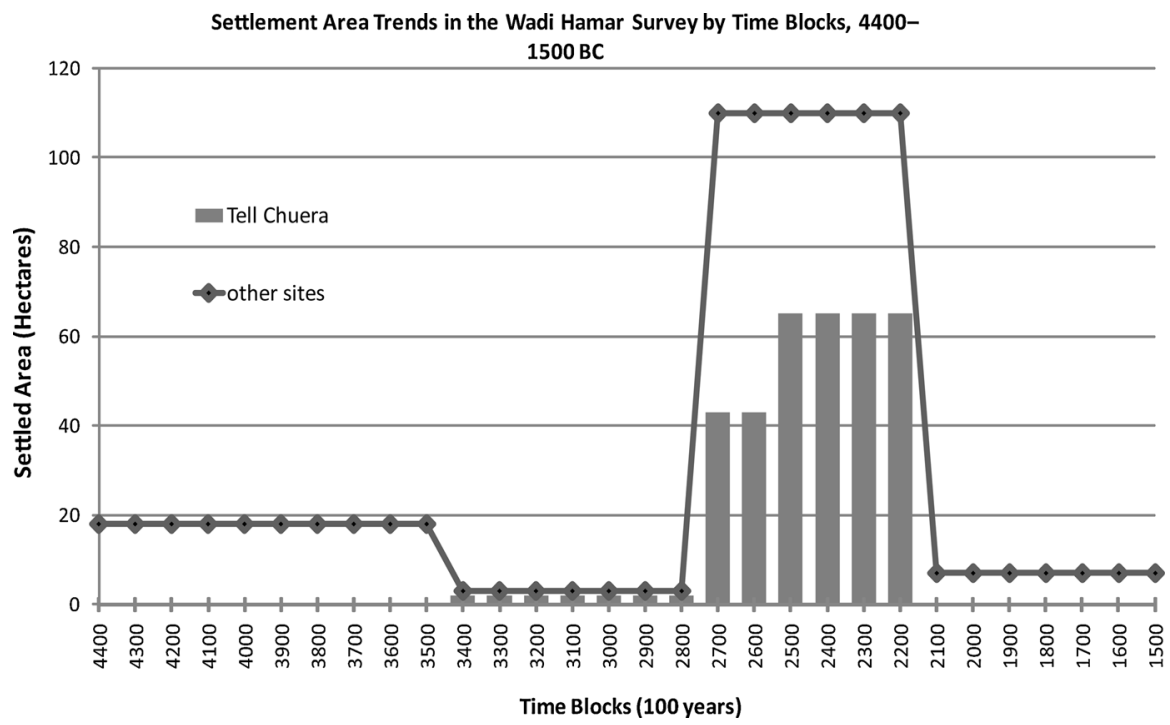

Fig. 10 Settlement area (in ha) in the Wadi Hamar survey area (Khabur-Balikh steppe) plotted according to 100 -year time blocks

2006) (Fig. 10). While some scatters of LC pottery exist, none constitutes a great enough concentration to suggest long-term occupation except at the main site of Tell Chuera, which, in very recent excavations, has shown some evidence of this (Dohmann-Pfälzner 
and Pfälzner 2002, pp. 13-14). Nevertheless, this small occupation was nowhere near the size reached by the site during the EBA, beginning in the early EJ 2 (c. 2800 BC) with the construction of the central mound (43 ha) and initial city wall, and continuing with the establishment of a concentric lower town and outer wall in the late EJ 2 (c. 2650 BC; total 65 ha). Concurrent with the settlement expansion on the main tell, the surrounding landscape saw a significant increase in small settlements; the survey identified 12 sites with a combined area of 120 ha from this period (Fig. 10). Additionally, several large tell settlements (over 10 ha each) were established, including Tell Dakhliz, Tell Ghajar el-Kebir, and 'Aghila (Fig. 9). This density of occupation continued for much of the third millennium BC, but both Tell Chuera and the smaller settlements appear to have been abandoned in the late third millennium (EJ 4-5). By the MBA, just two sites, with a combined area of 7 ha, can be identified. In the Chuera area, settlement therefore expanded very significantly and collapsed again, all between 2700 and 2200 BC (EJ 2-4).

On the eastern side of the Western Jazira, the Jebel Abd al-Aziz survey, covering an area of nearly $6,000 \mathrm{~km}^{2}$ around the eponymous mountain range, provides a similar picture (Kouchoukos 1998; Hole 1997). Here, Ubaid occupation is less than around Tell Chuera, with a total of 5 small settlements covering a combined area of 9 ha, which are then reduced to a mere 3 sites of indeterminate or negligible area during the LC. No large sites with fourth millennium occupation are known to exist in this area. As in the Chuera region, the Jebel Abd al-Aziz sees a surge in the number of sites and their areas around the middle of the EBA (EJ 3), with several large tells of over 10 ha each (e.g. Muazzar, Mabtuh Sharqi and Gharbi, Maghar, Hamam Sharqi) being settled on previously unoccupied sites (Fig. 9). In total, 36 sites from the mid third millennium (EJ 3) have been identified, and as in the Chuera area there is little evidence of substantial occupation by the late third millennium, with most sites being abandoned some time after EJ 3B (c. 2400-2300 BC; Kouchoukos 1998).

These settlement patterns, observed in geographically diverse areas of the Western Jazira, imply that the rapid and substantial increase in settled population at the start of the third millennium cannot have been drawn from any local sedentary source. Furthermore, the large sites of this period, which either belong to the double-walled Kranzhügel, or to citadel cities (as defined above), exhibit a greater level of social and infrastructural complexity than can reasonably be expected of nomadic peoples of the fourth millennium BC (Meyer 2010b).

The Middle Euphrates of Syria and Turkey (Figs. 11, 12, 13)

Here we summarize results of the Titriş, Kurban Höyük and Sweyhat surveys in northern Syria and southern Turkey; a fourth survey, the Land of Carchemish Survey, is not discussed, but has been presented in greater detail elsewhere (Fig. 11; Wilkinson et al. 2012; Peltenburg 2007).

\section{Titriş-Kurban Area}

The Titriş-Kurban area, situated within the northern zone of long-term sustainable settlement, includes one of the lesser agricultural plains near the Euphrates, as well as a landscape of river terraces along the Turkish Euphrates river. This area witnessed two periods of urbanization during the fourth and third millennia BC: the first in the later part of the Late Chalcolithic (LC 4-5) centred on Samsat Höyük, and the second in the mid-late EBA (c. 2600-2300/2200 BC) on Titriş Höyük (Fig. 12a, b). In the Late Chalcolithic, 


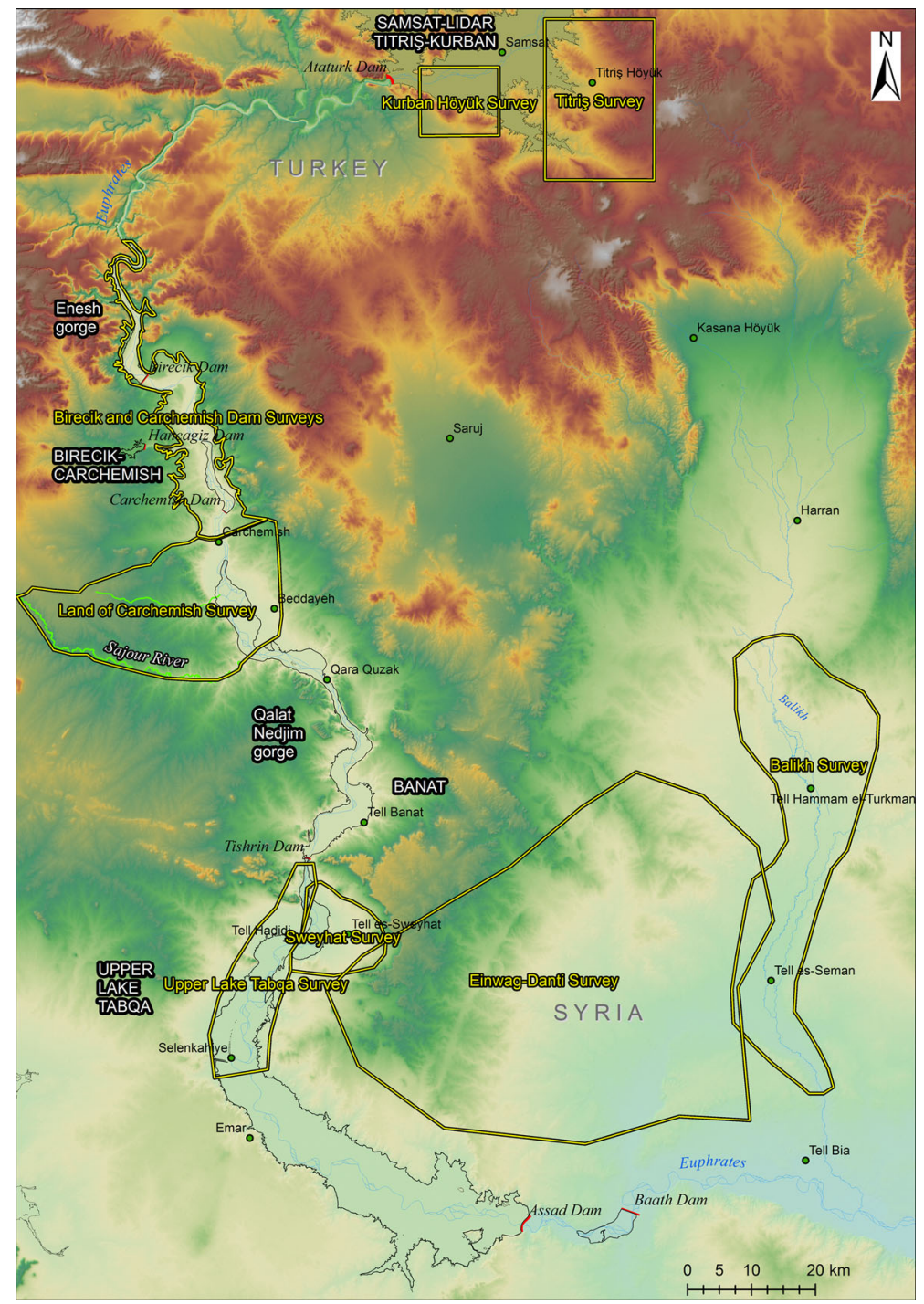

Fig. 11 Main sites and survey areas in the Turkish-Syrian Middle Euphrates (Color figure online)

when 15 ha Samsat was dominant, the remaining settlement was concentrated at small tells along the Euphrates river valley and a sparse scatter of settlements away from the river (Wilkinson 1990; Algaze et al. 1992; Wilkinson et al. 2012). During the early EBA (3100-2650 BC), Samsat did not expand but new sites, including the 5 ha main tell at Titriş, developed on the previously sparsely-settled plain south of the Euphrates. Settlement increased dramatically in this zone during the middle and late EBA (2650-2200 BC), with Titriş growing from 5 to 40 ha through the development of a substantial lower city and a halo of newly founded smaller sites (Algaze et al. 1992, 2001), along with an expansion of medium-sized 'town' sites, including larger tells along the river such as 

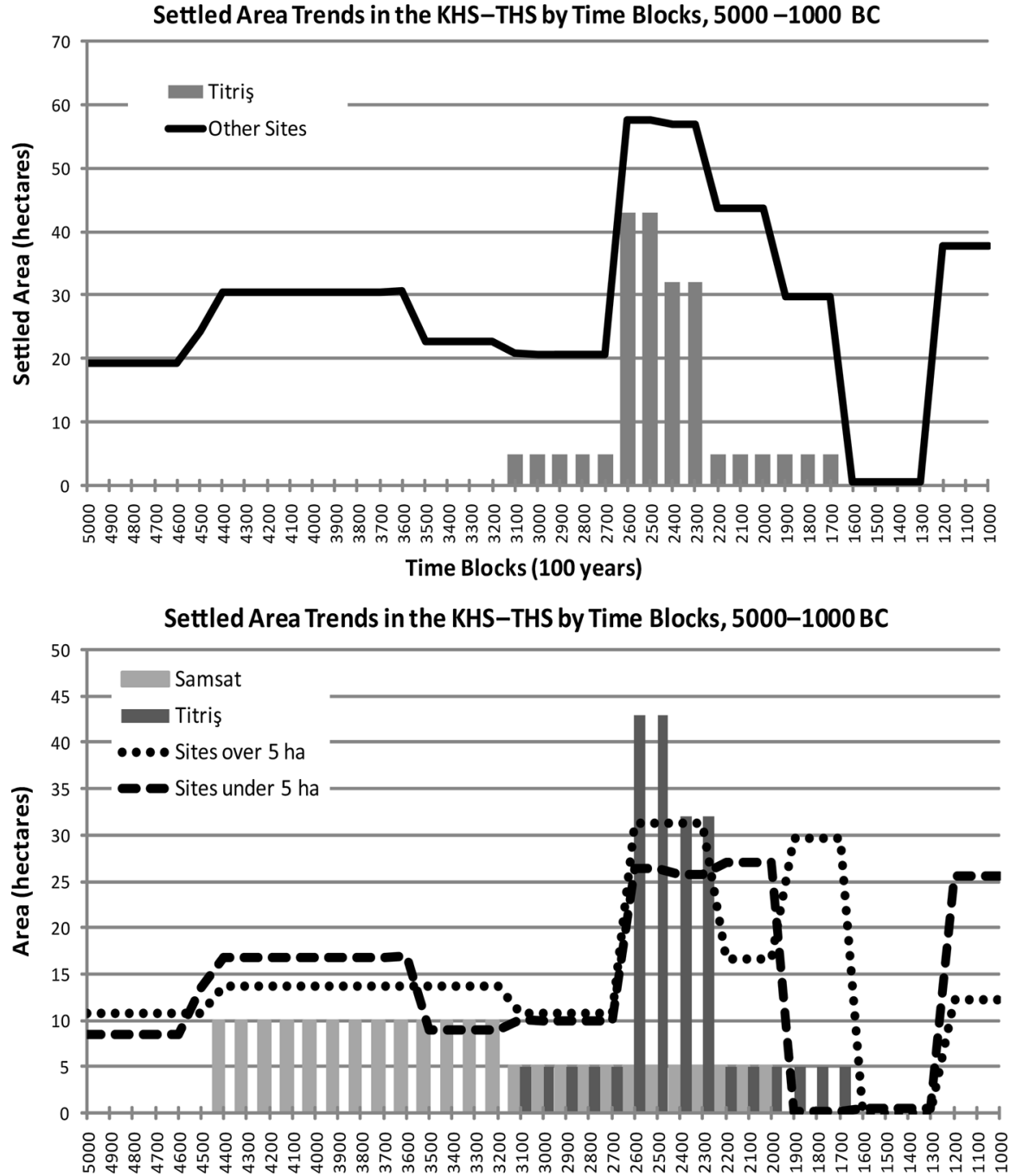

Time Blocks (100 years)

Fig. 12 Top aggregate settlement area for all sites within the Titriş-Kurban survey areas illustrated for 100 year increments (5000-1000 BC); below aggregate settlement area for the Titriş-Kurban-Samsat area sub-divided into two classes (a) small sites $<5$ ha (dashed line) sites $>5$ ha (dotted line) and (b) the main sites of Titriş Höyük (dark grey) and Samsat (grey). 5000-1000 BC

Kurban and Lidar. This expansion was short-lived, and by the end of the EBA both Titriş and the medium-sized sites had contracted significantly, while the number of small sites rose, perhaps indicating the dispersal of the populations into the surrounding countryside. Ultimately, these small sites were also abandoned as settlement declined still further during the early second millennium BC (MBA). Increased connectivity and trade (Algaze et al. 2001; Algaze 2012), and perhaps advantages gained from access to pastures away from the river, may all have contributed to this rapid growth of Titriş; equally, any decline in trade or the demand for wool may have contributed to its reversal. 


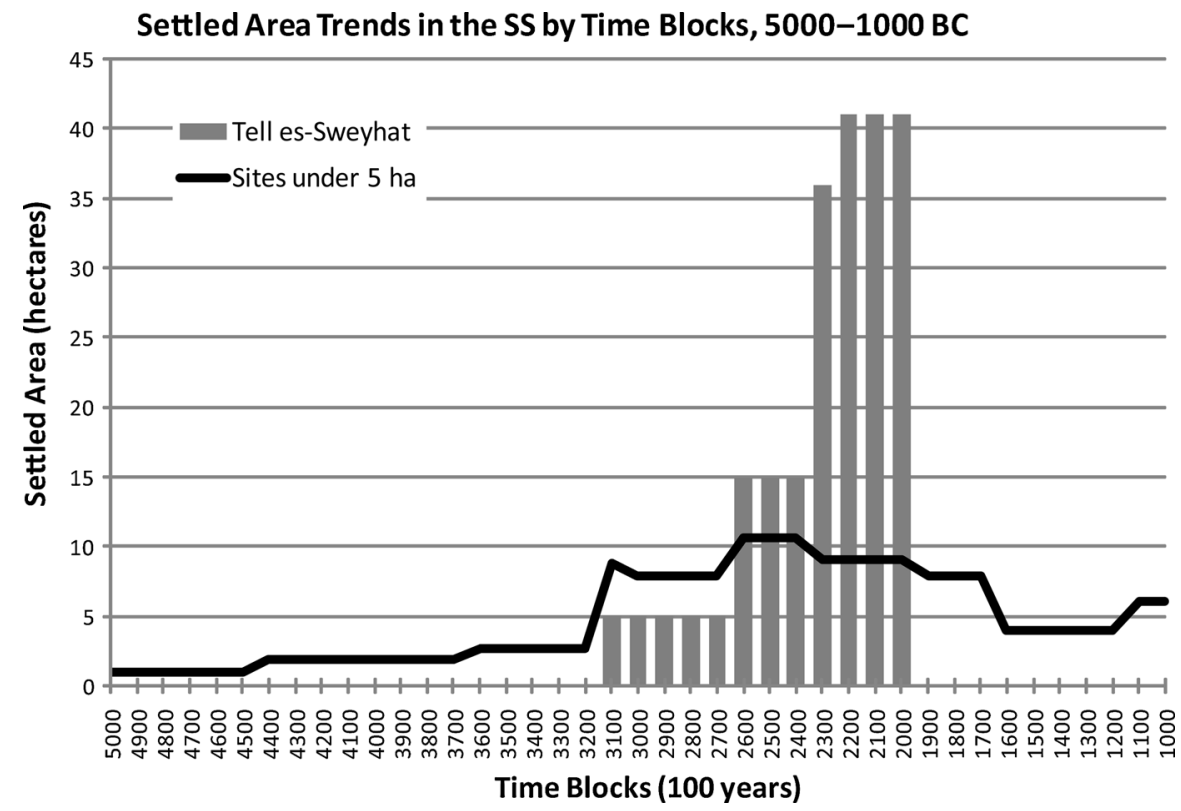

Fig. 13 The Tell es-Sweyhat Survey (SS), including Tell es-Sweyhat and other sites in the immediate survey area: 5000-1000 BC

\section{Sweyhat Region}

Further south around Tell es-Sweyhat-situated within an area of broad river terraces firmly within the agro-pastoral zone of uncertainty-the difference between Late Chalcolithic and EBA settlement is even more marked (Wilkinson et al. 2012). Only three very minor sites were occupied during the Late Chalcolithic, with a further possible occupation at Tell Hajji Ibrahim during the Uruk and early EBA periods (Danti and Zettler 2007). Early EBA settlement expansion is attested by 11 sites distributed across the plain, including the newly founded tell at Sweyhat (Fig. 13), which grew to some 15 ha in the middle EBA (c. 2650-2300 BC), and by the late EBA (c. 2300-1950 BC) had reached 42 ha. Like Titriş, Sweyhat was therefore surrounded by a halo of smaller sites and a scatter of battered sherds, the latter suggestive of manuring and intensification of agricultural production (Wilkinson et al. 2004). Alongside the urban development at Sweyhat, the 56 ha settlement at Tell Hadidi also reached its greatest extent at some point during the second half of the EBA (2650-1950 BC); however, due to chronological uncertainties, it is unclear whether this coincided with the rise of Sweyhat or pre-dated it. If the two sites were fully occupied simultaneously, this area would represent the most significant urban agglomeration west of the Upper Balikh and Khabur plains. However, the expansion of settlement and urban development did not survive the EBA-MBA transition and settlement declined significantly after the abandonment of Sweyhat itself (Cooper 2006; Danti and Zettler 2007).

Sweyhat therefore represents the rapid growth and decline of an urban centre and the attendant settlement system, with evidence for intensive agricultural production in a climatically marginal environment. However, unlike Hawa and Hamoukar (above), but more 
like the Khabur-Balikh steppe (above), rather than drawing upon any surrounding population for its growth, Sweyhat appears to have developed rapidly, attaining a size considerably greater than could have been achieved on the basis of any pre-existing local population. This implies that population to fuel the growing city was drawn in from an unknown area or unknown areas further afield.

In the Middle Euphrates as a whole, the Titriş, Land of Carchemish and Sweyhat surveys indicate that EBA settlement, rather than consisting simply of a strip along the Euphrates as suggested in earlier studies (Cooper 2006), was augmented by a consistent hinterland of small and medium-sized sites in the tributary valleys and across the plateaus away from the river (Wilkinson et al. 2012).

The Western Plains, Orontes and Homs Areas (Figs. 14, 15, 16)

The Orontes Valley around Homs consists of three main physical regions: the Orontes Valley proper, the marl agricultural plain which extends eastwards from the river until it merges with the limestone geology closer to the steppe, and an undulating basaltic region west of the river. The marl landscape slopes gently from southeast to northwest, and is cut by a number of shallow wadi systems which flow towards the Orontes (Philip et al. 2002, p. 5; Fig. 14); annual rainfall ranges between $500 \mathrm{~mm}$ and $300 \mathrm{~mm}$, providing a viable agricultural base.

\section{Chalcolithic}

The local Late Chalcolithic is characterized by distinctive chaff-tempered pottery, first identified at Tell Nebi Mend (Matthias 2000, p. 419, fig. 23.3). Radiocarbon dates indicate that this material had appeared on the site by c. $4000 \mathrm{cal} \mathrm{BC}$, and continued in use for much of the fourth millennium. In the marl landscape, Chalcolithic sites, mainly of 1-3 ha in extent, are concentrated along the Orontes or on tributary wadis. The two largest sites appear to be Tell Nebi Mend south of Homs, and SHR 94 (SHR = Settlement in the Homs Region), located on a terrace east of the Orontes, $8 \mathrm{~km}$ north of Homs - and like Nebi Mend, located where a tributary stream joins the Orontes. SHR 94 was around 5 ha in extent, while at Nebi Mend the recovery of Late Chalcolithic architecture within the single deep sounding excavated through the overlying 9 ha tell suggests an occupation in the 5-9 ha range.

\section{The Early Bronze Age}

A recently identified body of 'EBA' ceramics that is distinct from both the Late Chalcolithic and the EB IV (Matthias 2000, pp. 422-425), appeared around 3400/3300 cal BC, according to recent (as yet unpublished) radiocarbon dates. This period (termed simply generic EBA to distinguish it from EB IV-finer distinctions are not yet possible), witnessed the crystallization of the pattern of tell settlements that was to dominate the local landscape from the third millennium BC until the Roman period (Fig. 15). The strong continuity of settlement, from the 'EBA' into EB IV, represents little more than a consolidation and modest augmentation of regional settlement. As the time-block plot reveals (Fig. 16), the situation in EB IV is one of stability, with Tell Nebi Mend perhaps attaining something close to its later size of 9 ha, and forming the main regional centre (Fig. 16). 


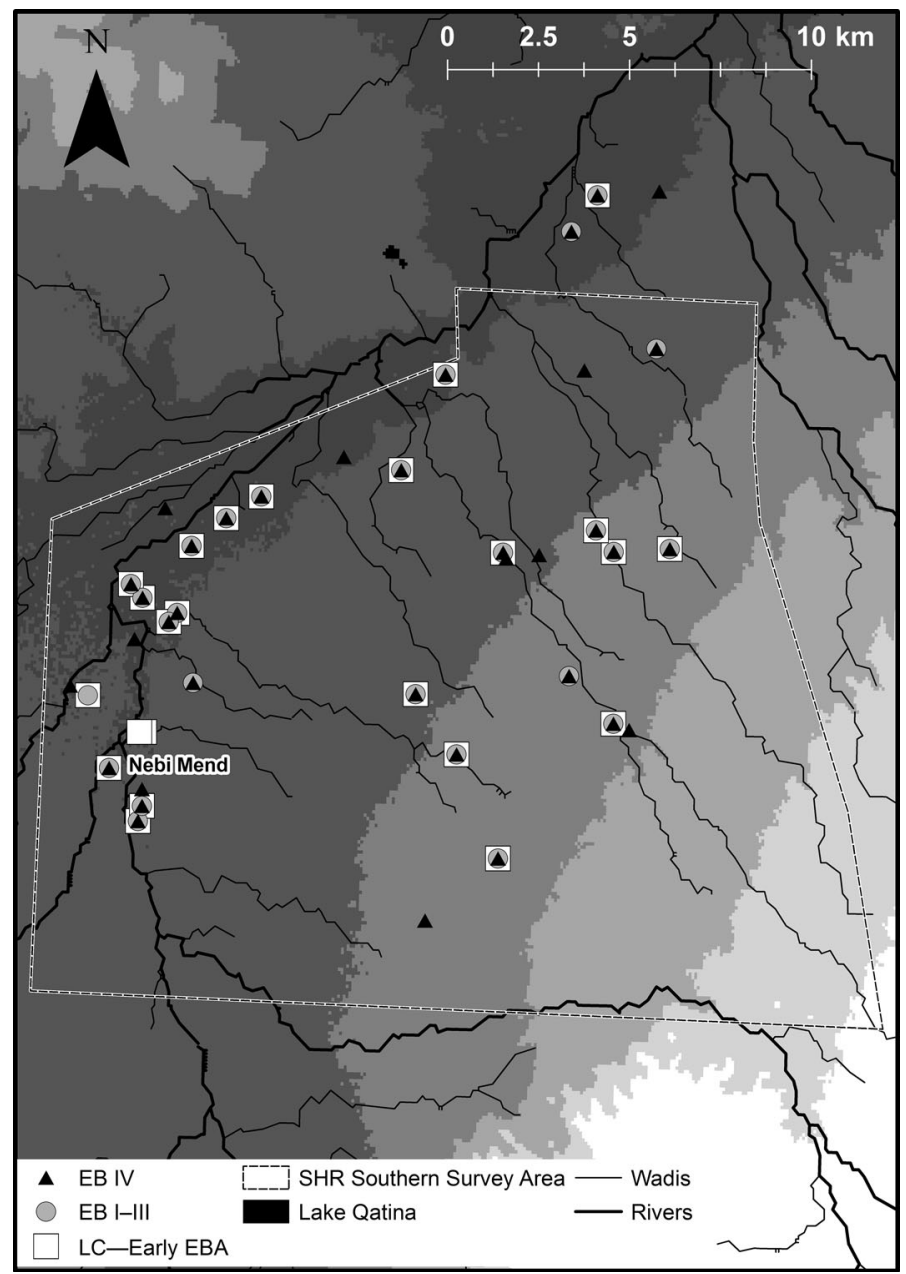

Fig. 14 The Homs area (SHR) showing the main Late Chalcolithic (LC) and Early Bronze Age (EBA) sites

The Chalcolithic-EBA periods are also marked by settlement activity of modest scale in the basalt landscape west of the Orontes. Along the main water courses this takes the form of small, c. 1 ha, settlements of unclear morphology, frequently buried below later tells or modern villages, and groups of stone enclosures on the higher ground (Philip and Bradbury 2010).

There is a clear contrast between the Orontes Valley and the adjacent plains, and areas further to the east: in the former the basic settlement structure took shape during the fourth millennium $\mathrm{BC}$, and was modified incrementally during the third millennium. East of Homs, beyond the $300 \mathrm{~mm}$ isohyet and in the steppe margins northeast of Hama, there is little evidence for settlement activity between the sixth and the mid third millennium BC, but a very marked expansion of activity during EB IV (al-Maqdissi 2007; Castel 2007; Castel and Peltenburg 2007, p. 613; Geyer and Calvet 2001; Geyer et al. 2007; Morandi Bonacossi 2007). While Qatna itself receives around $350 \mathrm{~mm}$ of rainfall annually, other 


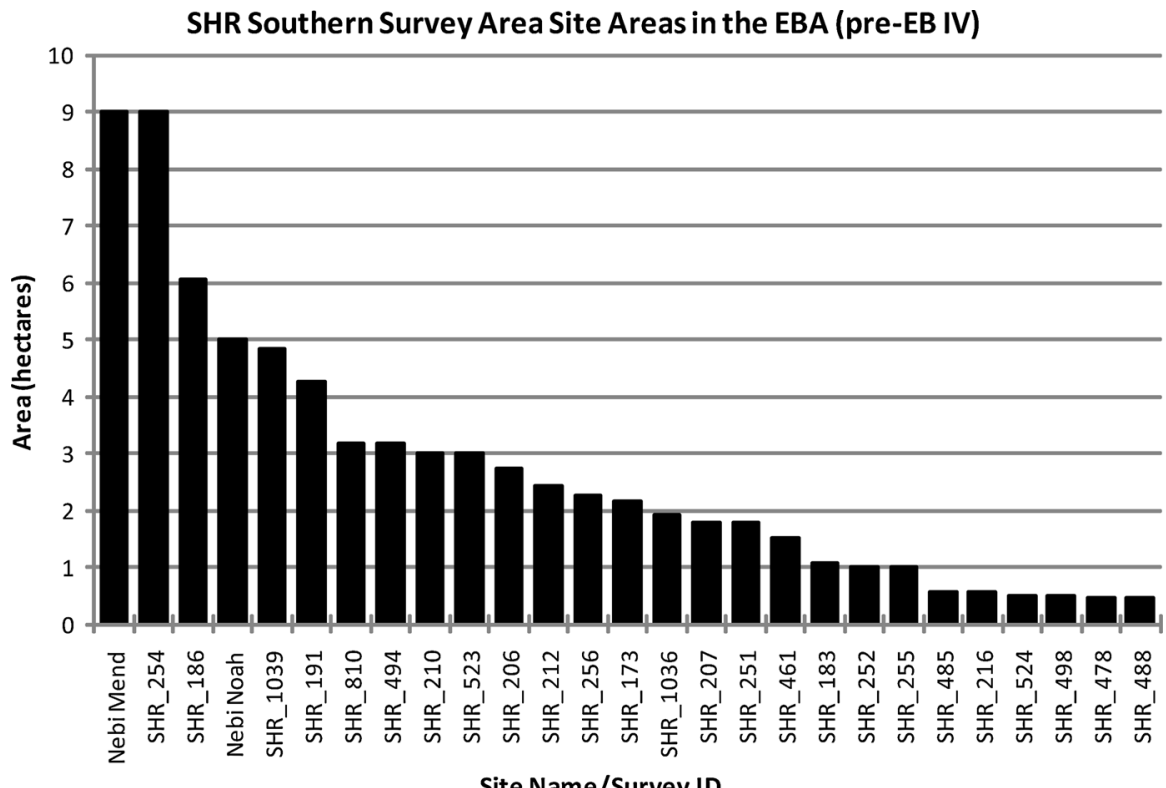

Site Name/Survey ID

Fig. 15 Early Bronze Age (EBA) occupations (in ha) in the Southern Survey Area of the Syrian-British Homs Survey. Note that some of these areas refer not to classic tells but to low or flat scatters: areas for sites such as Tells Nebi Mend and Nebi Noah are estimates because early occupation is buried below large later tells

substantial EB IV settlements such as Tell Sh'eirat, Tell es-Sour (al-Maqdissi 2007; Fig. 1) and al-Rawda (Castel 2007; Fig. 1) lie clearly within the zone of uncertainty, as defined here.

In summary, the evidence from the Homs survey suggests that the Orontes Valley and its associated agricultural plains formed a stable settlement 'core', and that the expansion of settlement to the east during EB IV is yet one more regional variant of the exploitation of the zone of uncertainty. Moreover, the Très Long Mur, a low stone wall, probably a territorial marker, which extends for $220 \mathrm{~km}$ east of Hama and Homs, before turning west towards the Anti-Lebanon range, has been provisionally dated to EB IV (Geyer et al. 2010). The line of the wall corresponds closely to the eastern limit of the zone of uncertainty and may represent a physical expression of the boundary between the 'cultivable' and uncultivable steppe.

\section{Late Chalcolithic Settlement in the Northern and Western Fertile Crescent}

Archaeological and ecological data from the selected surveys help define a northern and western zone of apparently sustainable settlement that is distinguishable from the southern and eastern zone of uncertainty (Figs. 3, 17). In the former zone, a relatively abundant scatter of Late Chalcolithic 1-3 sites (i.e. late fifth to mid fourth millennium BC) features occasional major LC centres such as Nineveh (Stronach 1994), Tell al-Hawa (Iraq; Ball et al. 1989) and Brak in the greater Khabur plains (Ur et al. 2011); further west, major LC sites are found at Samsat (Turkish Euphrates: Algaze 1999, 2008, p.118), Oylum Höyük 


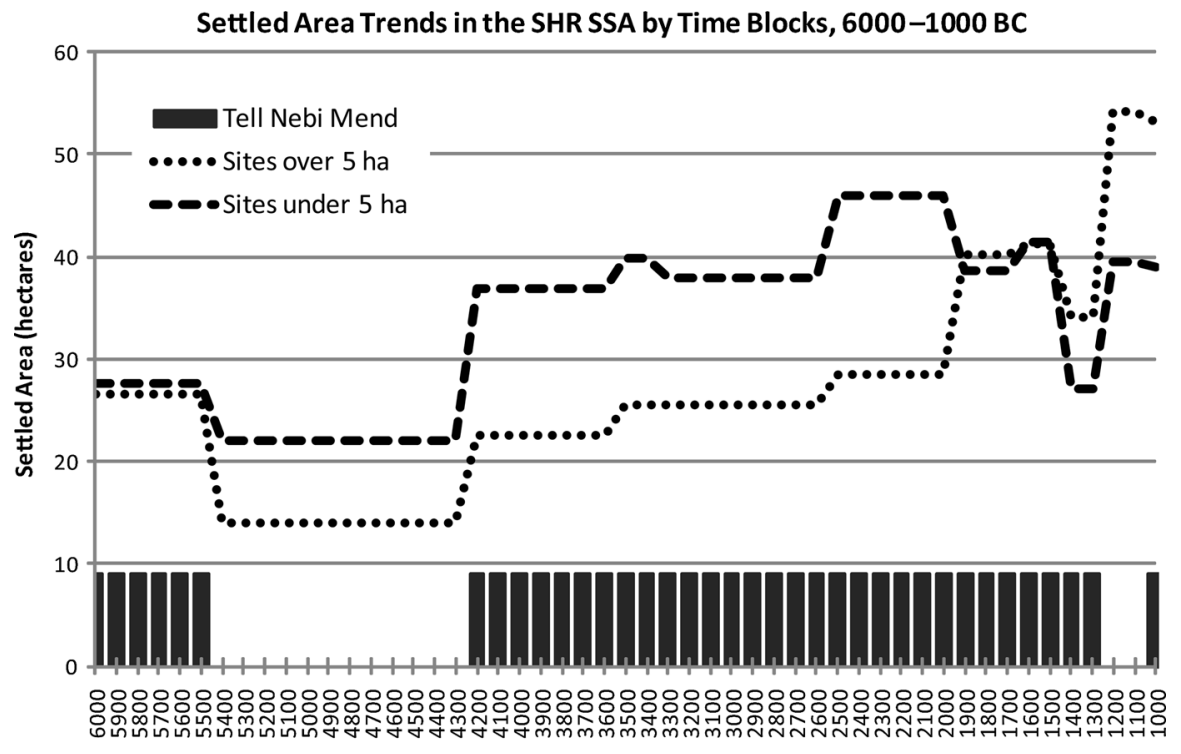

Time Blocks (100 years)

Fig. 16 Aggregate settlement area for the Southern Survey Area of the Syrian-British Homs Survey 6000-1000 BC, sub-divided into two classes (a) small sites $<5$ ha (dashed line) and sites over 5 ha (dotted line). There is a well-documented gap in occupation at Tell Nebi Mend during the mid sixth-late fifth millennium BC. Settlement remains fairly stable through Late Chalcolithic and EBA, and shows only a modest increase in EB IV. This contrasts with the situation in the zone of uncertainty to the east of Homs, where the EB IV is a period of major settlement expansion

(Afrin Valley, Turkey: Özgen and Helwing 2003) and Imar al-Sharqi (Amuq, Turkey: Casana and Wilkinson 2005). The additional presence of LC 1-2 Khirbet al-Fakhar (Hamoukar, northeast Syria), with its compelling evidence for a 300 ha node in the obsidian trade, attests to the significance of connectivity for the development of proto-urban centres (al-Quntar et al. 2011; Khalidi et al. 2009). To the west, a rather weakly-defined zone of Late Chalcolithic settlement appears to have extended along the Orontes Valley. Overall, however, the archaeological record can be interpreted as suggesting that in the fourth millennium BC, urbanization was only evident in the Khabur basin and adjacent areas, not in the middle or upper Euphrates nor the upper Tigris regions (Frangipane 2010, p. 82; Frangipane 2012, pp. 34-35). Within drier marginal areas, pre-third millennium settlement was rare, the most noteworthy concentrations being the intrusive southern Uruk centres of Sheikh Hassan, Habuba Kabira and Jebel Aruda in the Middle Euphrates Valley, as well as the 12.5 ha Chalcolithic mound of Tell Zeydan in the lower Balikh (Stein 2012).

Overall, a band of fourth millennium BC settlement can be distinguished across the northern Fertile Crescent (Fig. 17). The following estimates (in terms of sites per $100 \mathrm{~km}^{2}$ ) are based on the sample survey areas, cross-checked where possible with other relevant surveys (Fig. 18):

1. Dense LC settlement predominates within the greater Khabur plains, extending west to Tell Beydar where site densities, although somewhat lower, remain significant (see Stein 2012, p. 147, for similar trends). 


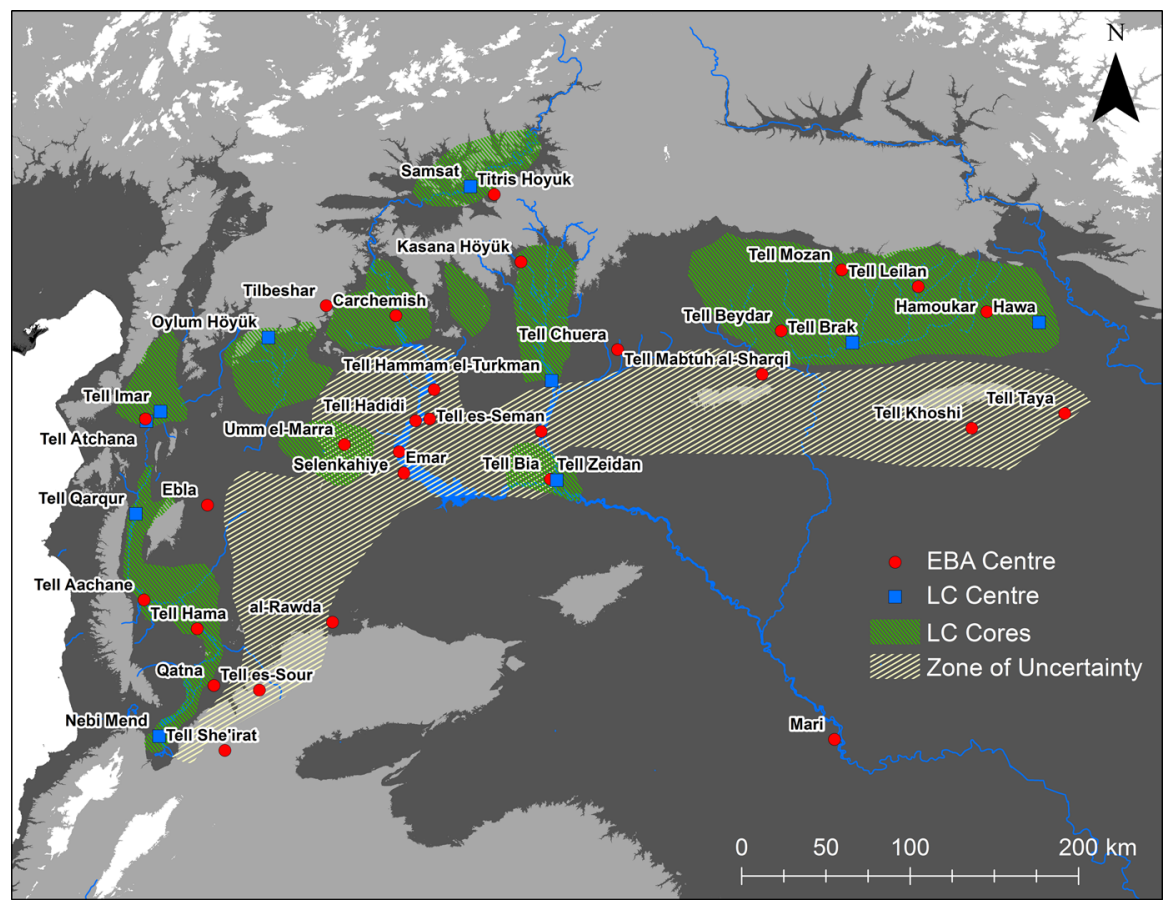

Fig. 17 Major sites of LC and EBA date in the northern Fertile Crescent. The pattern of significant LC settlement delimits a zone of long-term sustainable settlement. Note the major EBA sites within the zone of uncertainty (Color figure online)

2. The steppe between the Khabur and Balikh was only sparsely settled by sedentary communities at this time (Hole 1997).

3. An attenuated but still significant density of LC settlement is recognizable in the northern Balikh Valley (north of Tell Hammam et-Turkman) and in the Harran plain (Turkey).

4. In the Middle Euphrates, LC settlement occurs mainly on river terraces, tributary valleys and adjacent plains to the north of the river Sajur, with the large mound of Samsat probably constituting a major LC centre (Algaze 1999, p. 538; Wilkinson et al. 2012).

5. Moderately dense LC settlement occurs in the Umm al-Marra area (Schwartz et al. 2000).

6. In western Syria, the Orontes Valley appears to have been a focus of long-term settlement from the Neolithic and Chalcolithic. Tells Nebi Mend, Hama and Qarqur (Matthias 2000; Thuesen 1988; Casana, in press) offer examples of its emergent centres. Similarly, the Amuq and Afrin Valleys were major foci of Neolithic and Chalcolithic settlement, so that by the fourth millennium BC major centres had developed at Imar al-Sharqi (Casana and Wilkinson 2005, p. 36) and Oylum Höyük (Özgen and Helwing 2003) within a matrix of smaller sites.

The number of sites per unit area (per $100 \mathrm{~km}^{2}$ ) demonstrates that Late Chalcolithic urban centres developed within a matrix of relatively dense settlement, a pattern which is particularly evident within the greater Khabur plains (Wright et al. 2006-2007, fig. 3; 


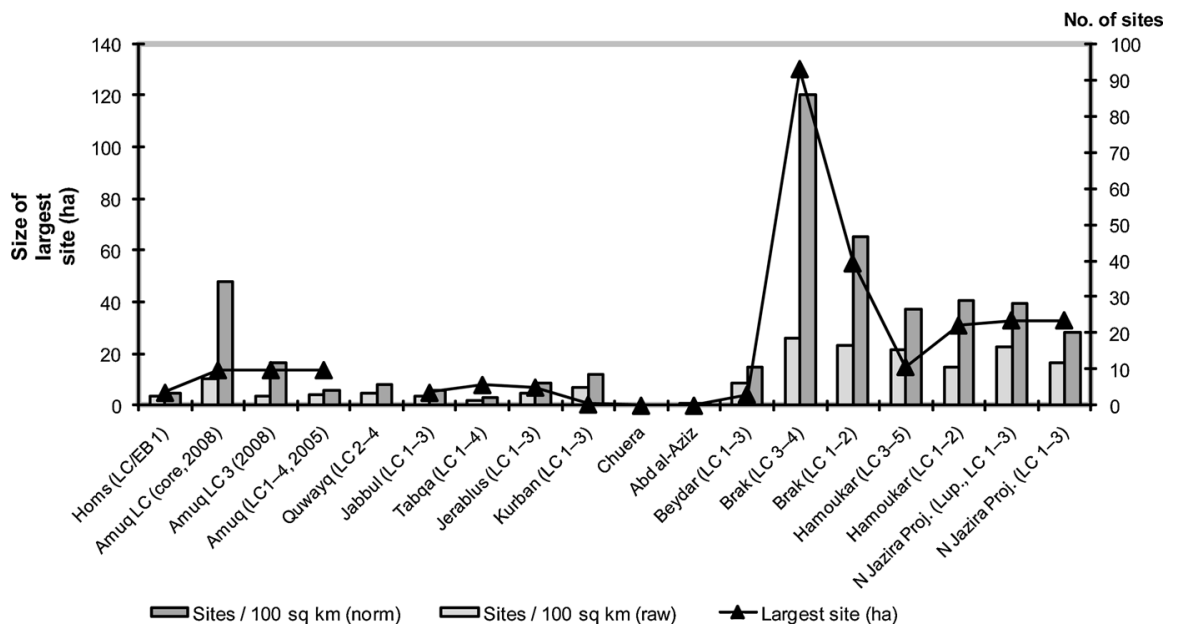

Fig. 18 Chart showing the density of Late Chalcolithic sites per $100 \mathrm{~km}^{2}$ and the area of the largest site in any one survey area. Survey areas are indicated from east (NJP) to west (Homs); grey bars indicate the number of sites per $100 \mathrm{~km}^{2}$ in each survey area (raw data: without allowance for the different lengths of ceramic periods); dark grey bars indicate the number of sites per $100 \mathrm{~km}^{2}$ normalized to a standard length of the LC period of 1,400 years. The line indicates the size of the largest site (ha) in each survey area. For the Amuq, 'core, 2008' refers to estimates for the core area of the Amuq, from Gerritsen et al. 2008; '2005' is from Casana and Wilkinson 2005. N Jazira Proj. (Lup. LC 1-3) refers to Lupton (1996)

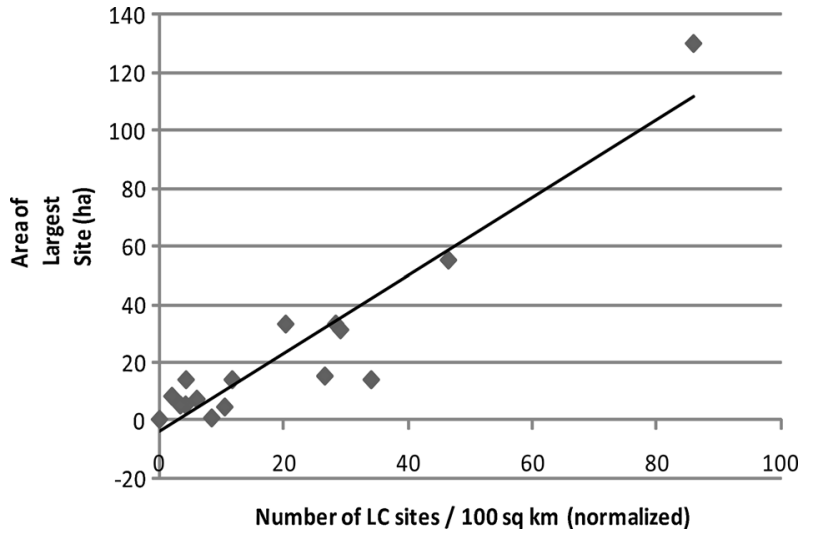

Fig. 19 Correlation between the density of LC sites and the area of the largest LC site in each survey area (for normalized data as indicated on Fig. 18). Note that the size of the Hamoukar southern site is taken as 31 ha (namely the mounded area). The correlation coefficient of the regression line $\left(\mathrm{R}^{2}\right)$ is 0.8805

Fig. 18). There is also a correlation between the size of the largest site in any survey region and the density of LC sites per $100 \mathrm{~km}^{2}$ (Fig. 19). These are shown in Fig. 19 in terms of the 'normalized' and 'raw' data; the former has been recalculated to take into account the area of the surveys in question. Although the correlation is high, one anomaly, namely Khirbet al-Fuqar, is an unusual site (al-Quntar et al. 2011). However, when the mounded area of the site ( $31 \mathrm{ha})$ is employed instead of the area of artefact spread and soil discolouration (280-300 ha), the correlation is higher (0.88 on Fig. 19). It is particularly 
distinctive of this phase of urbanization that (a) the main sites are distinguishable by their sheer bulk [in other words, they are both spatially extensive (c. 15-50 ha) and high with steep sides, implying that mounds grew large, but at a relatively steady pace]; and (b) some mounds, such as Tell Brak, display a surrounding scatter of low outer mounds which were not contained within a clearly defined city wall (Ur et al. 2011). Similarly, Hawa appears to have had an extensive lower town, although this is less evident because it is mainly obscured by the modern village (Ball et al. 1989, pp. 39-40, fig. 9).

Because of the various periodizations employed for the Late Chalcolithic, estimated site densities vary according to how finely the period has been sub-divided by the surveyors. Where the period has been sub-divided into only two phases, namely LC 1-3 and LC 4-5 (Uruk) (as was the case in the NJS; Lupton 1996), settlement density appears higher, whereas with further sub-division, there are fewer settlements of any one phase, with the result that settlement density appears lower (Brustolon and Rova 2007, figs 9-12). Because not all survey records have been divided in accordance with the full LC 1-5 sub-divisions, we have chosen here, as far as possible, to plot settlement density of phases LC 1-3, which provides a reasonable estimate of 'local' Late Chalcolithic settlement (Table 1). Overall, within the greater Khabur plains, the Late Chalcolithic appears to have been a period of relatively dense settlement, consisting of a wide range of small, medium and large settlements dispersed across the plains to form a two or three level settlement hierarchy. West of Tell Beydar, LC settlement becomes attenuated or limited to minor valleys and tributaries of the Euphrates and associated upland plains, largely (but not entirely) restricted to the northern part of the rain fed zone (Figs. 2, 4). This distribution outlines what can be described as a zone of sustainable settlement to the north and west, and the zone of uncertainty to the south and east, where LC settlement is sparse or absent. The significance of this will become evident below.

In the upper Khabur plains, LC proto-urban settlements developed within a moderately dense matrix of rural settlement, which provided the context for the fourth millennium BC phase of urbanization. Similar arguments for the development of early cities have been made by Boserup (1983, pp. 68-69) as well as Drennan and Peterson (2012, p. 74). In fact the latter, building on the earlier arguments of Boserup, suggest that where population densities are high, 'costs' of interaction are lower because there are more people available within any given area to interact with. High population densities encourage not only interaction but conflict (Carneiro 1970). This model, which is probably also applicable to the North Jordan Valley in the late fourth millennium BC, assumes that under conditions of circumscription aggressive chiefs or kings enlarged political units into larger polities (Carneiro 1970; Flannery 1999). It is therefore possible that recent evidence for mass graves at both Brak and Hamoukar in northeastern Syria may result from such conflicts (Reichel 2006-2007; Lawler 2006; McMahon et al. 2011; Algaze 2008, p. 70; Stein 2012, p. 141). Although moderately dense rural settlement may have prevailed within parts of the Khabur plains, most other parts of the northern Fertile Crescent were more sparsely populated. In such locations the growth of centres such as Samsat, Oylum Höyük or Imar al-Sharqi may either have been driven by factors such as increased regional connectivity, or developed where local pockets of higher population density existed.

For the subsequent LC 4-5, significant Uruk activity demonstrably occurred within the densely occupied LC settlement zone of the upper Khabur plains, but also in the less populated regions to the south. Specifically, southern Uruk material culture is particularly evident within the Uruk 'enclave' of the Middle Euphrates of Habuba Kabira South (Strommenger 1980); Jebel Aruda (van Driel and van Driel-Murray 1983); and Tell Sheikh Hassan (Boese 1995; Algaze 1993). In other words, rather than forming part of the 
'colonial expansion' characteristic of the Habuba Kabira area, settlements in the Khabur region can be described as Uruk-related, with a mix of local and southern types (Schwartz 2001, p. 255). Therefore evidence from archaeological surveys supports the suggestion by Schwartz that the Uruk cluster around Habuba Kabira in the Middle Euphrates developed to the south of the main zone of Late Chalcolithic settlement, perhaps in order to avoid this zone (Schwartz 2001, p. 260; Wilkinson et al. 2012, pp. 159, 170-172). However, the location of these colonies might also be explained by the high connectivity of the area, commanding the bend of the Euphrates, and by the attractiveness of the marginal zone for opportunistic sheep husbandry (Wilkinson et al. 2012, fig. 25). Similarly, Algaze points out that Habuba and neighbouring sites developed in 'carefully selected locations near historical fording places in the Euphrates bend', which made ideal collection and transshipment points (Algaze 1993, 2008, p. 72). The presence of such major loci of Uruk activity underscores the significance of marginal or 'sub-optimal' areas, which should not therefore be evaluated upon their perceived agricultural potential alone.

\section{Settlement and Landscape in the Third Millennium BC in the Northern Fertile Crescent}

The pattern of dense Late Chalcolithic settlement and associated urbanism gave way, during the Ninevite $\mathrm{V}$ period of the early third millennium BC, to a phase of reduced social complexity (Rova and Weiss 2003; Akkermans and Schwartz 2003, pp. 231-232). In the extensive agricultural plains of northern Syria, Ninevite V was followed by a new phase of urban-scale settlement during the mid and late EBA (2600-2000 BC), characterized by Akkermans and Schwartz (2003, pp. 253-262) as the 'second urban revolution' and corresponding to Ur's second phase of urbanization (Ur 2010a, pp. 404-412). During this phase, which begins around the mid third millennium BC, within the extensive agricultural lowlands of northern Syria settlements grew to some 100-120 ha, in association with a distinctive settlement hierarchy. In contrast, in the valleys of the Euphrates and its tributaries, sites are clustered on river terraces or extend up tributary valleys either as alignments or in the form of muted hierarchies (Wilkinson et al. 2012). North of an alignment following the Sajur River and the east end of the Jebel Sinjar (Fig. 4), settlement shows evidence of being long-term and potentially sustainable, whereas to the south in the marginal agro-pastoral zone or zone of uncertainty, settlement was more scattered and of attenuated duration (Lewis 1987, p. 16). Archaeological surveys demonstrate that in the moister zone of North Mesopotamia and western Syria, most EBA settlements are typically small, 1-3 ha, tells (Philip 2007; Wilkinson et al. 2012). In North Mesopotamia, when large settlements did develop they frequently grew rapidly during the mid-late third millennium BC into either extensive 'citadel cities' or Kranzhügel (as discussed above). Whereas the pattern of citadel city development is less evident in western Syria, in the climatically marginal steppe between the Khabur and Balikh Rivers both citadel cities and Kranzhügel formed a distinctive feature of the settlement landscape for much of the third millennium BC (Fig. 17). Particularly noteworthy is that, as discussed above, many enlarged sites were located further south than might have been expected on the basis of agricultural productivity alone, and lay within the zone of uncertainty in areas which posed a higher risk for sustainable cereal cultivation. This is evident on Fig. 20, which indicates settlement size (in ha) in relation to the mean annual rainfall.

Noteworthy sites within the zone of uncertainty include Banat-Bazi (30 ha); Sweyhat (40 ha); Hadidi (56 ha); Umm al-Marra (25 ha); Tell es-Seman (c. 50 ha); and Khoshi 

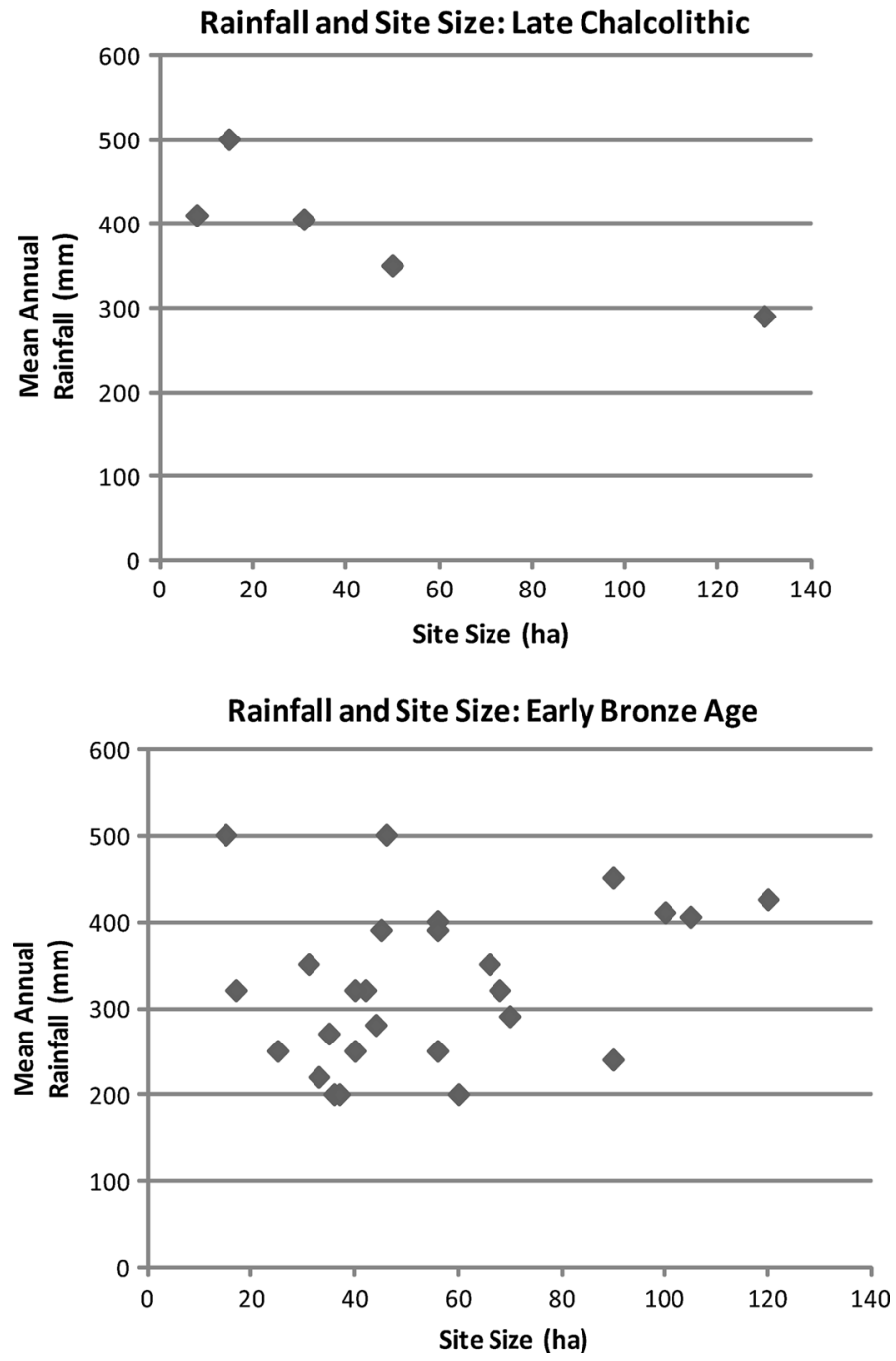

Fig. 20 Preliminary record of the area of the largest EBA sites in the northern Fertile Crescent vs. Mean Annual Rainfall (the grey area indicates the zone of uncertainty). Left major Late Chalcolithic sites; right Major EBA sites. Because mean annual rainfall figures vary depending upon the record period, these must be viewed as approximate

(90 ha) (Figs. 17, 20). These sites appear to be equivalent, at least in terms of their main EBA phases of occupation and ecological location, to the extensive, often geometric, cities of the dry steppe within the Kranzhügel zone of the Khabur-Balikh steppe discussed above. Although there are no obvious sites of this kind within the Orontes Valley proper, sites such as Tell es-Sour, Sha'irat and Rawda in the semi-arid steppe east of Hama and Homs appear to belong to an equivalent phase of EB IV expansion into the zone of uncertainty (Geyer and Calvet 2001; Geyer et al. 2006; Maqdissi al-Maqdissi 2010; Castel and Peltenburg 2007). 
In the mid third millennium BC, urbanization therefore took a very different form from the large bulky mounds of the Late Chalcolithic. Former LC centres such as Brak and Hawa saw urbanization spill outwards to form ill-defined outer settlements (Ball et al. 1989; Ur 2012). In other cases, tells of modest scale grew rapidly into large citadel cities, extending over 30-120 ha. Therefore the form, context and dynamics of the secondary urbanism of the mid third millennium BC contrast markedly with the preceding Late Chalcolithic. Not only were EBA centres such as Hamoukar, Leilan, Brak and Hawa developed within a dense matrix of rural settlement (Figs. 6, 8), some were also associated with settlement reorganization. Thus in the case of Tell al-Hawa, a distinctive settlement hierarchy developed at the same time as the western region was deserted (Fig. 6). Elsewhere, citadel cities such as Tell es-Sweyhat and those in the Khabur-Balikh steppe developed in previously under-populated areas; their growth can therefore hardly be ascribed to the existence of high local population densities, as in Boserup's earlier models (1983, pp. 68-69). This point emerges strikingly on the time-block plots (Figs. 10, 13). Even where expanded citadel cities such as Titriş Höyük are found in relatively verdant areas of 'sustainable settlement' they appear to have developed away from the main pockets of denser LC settlement (in this case on the Euphrates near Samsat), and, again, their growth may therefore have been fuelled by adventitious factors (Algaze 1999, p. 555; Wilkinson et al. 2012). Further discussion of third millennium BC urbanism in the southern Levant follows below.

\section{An Integrated Model of Agriculture Cores and Pastoralism}

\section{Settlement Expansion Out of Core Areas}

In the Middle Euphrates and the Khabur-Balikh steppe, the initial expansion of settlement into the zone of uncertainty and on to the steppe, as well as the opening up of previously settled land in the North Jazira plain, took place around 3000 BC (the Ninevite V period), that is, during a period of reduced social complexity. Excavations at Tell Chuera (above) and Tell es-Sweyhat (Danti and Zettler 2007, pp. 167-169) suggest that this initial occupation took place around 2800-2900 BC, or slightly earlier during LC 5 (i.e. the late Uruk period, towards the close of the fourth millennium BC). In contrast, settlement of the central Syrian steppe at al-Rawda was significantly later, during EB IV (c. 2400 BC; Castel and Peltenburg 2007, p. 602). Within the North Jazira of Iraq, the opening up of the formerly settled landscape of the western survey area around $3000 \mathrm{BC}$ (Figs. 6, 7) suggests a significant need for grazing land, perhaps in response to the growing interest in wool and textiles throughout greater Mesopotamia and the northern Fertile Crescent. This requirement for pasture would have intensified because the area of Hawa and Hamoukar was relatively densely settled during the fourth millennium and there would have been little open land accessible for grazing and hunting. In contrast, those settled in areas in the vicinity of open lands such as the Khabur-Balikh steppe would have been in a position first to use that land as pasture, and then, subject to existing claims and local power relationships, to claim such lands for more sustained settlement. Although the precise chronological relationships between Ninevite V settlement in the agricultural lowlands and the settlement of the steppe of northern Syria are still uncertain, it is plausible that the colonization of the Khabur-Balikh steppe and neighbouring marginal steppe built upon an earlier phase of minimal sedentary occupation and ancestral pastures that had been in use during the fourth and perhaps early third millennium BC. Therefore any apparent stasis or 
decline in the Ninevite $\mathrm{V}$ settlement zone may simply be a result of the movement of population from the Ninevite $\mathrm{V}$ heartland of northwestern Iraq and northeastern Syria into the steppe (Kouchoukos 1998). A similar expansion out of a core area might be apparent in the Homs region and the southern Orontes Valley, where there is a marked contrast between the 'landscapes of tells' near the Orontes and Qatna, and the eastern steppe, where a later phase of short-term settlement is evident in EB IV (Geyer and Calvet 2001, Geyer et al. 2007; Philip 2007, p. 239). However, the sheer scale of activity during EB IV suggests that the population of the west Syrian steppe may have drawn upon areas well beyond the Orontes Valley.

\section{The Role of Ancestral Pastures}

The apparent expansion on to the steppe, and its colonization by large-scale sedentary communities, raises the immediate question: why were such seemingly inhospitable areas selected for settlement? Emerging evidence from several areas suggests that it is possible to infer earlier phases of land use, perhaps as pasture. For example, reinterrogation of the field records of the Tell es-Sweyhat survey suggests that occasional sparse scatters of chaff- and coarse-tempered ceramics occurred on the plain around Sweyhat. Although not datable with precision, these scatters may be the remains of temporary encampments of communities that were using the area, perhaps for grazing purposes (Wilkinson et al. 2012). In other words, the rapid urbanization phase in the third millennium BC may have been preceded by a phase of extensive grazing combined with transitory settlement. Such activity would have given the communities some ties and perhaps claims to the land.

Such arguments are particularly compelling where monumental tombs occur, as is the case in the Euphrates Valley (Cooper 2006; Porter 2002, 2012); the basalt landscapes of the Homs region (Philip and Bradbury 2010, p. 163; Bradbury and Philip 2011, pp. 176-177; Bradbury 2011); or the upland regions of the southern Levant (Philip 2003). Similarly, the basalt plateau west of Tell Beydar (Wilkinson 2002) shows abundant evidence for 'marking' of the landscape, in this case via rock art (Van Berg and Picalause 2003). Such marking may plausibly have been connected with ancestral claims to that land, a model that can be applied to other areas that were seemingly unoccupied during the fourth millennium. For example, in both the Khabur-Balikh steppe and central Syria, formerly open areas of land ideal for pasture or hunting may have been within the bounds of selected communities that were long-term residents elsewhere, either within the zone of sustainability or beyond. Such 'ancestral pastures' would then have become the locus of sedentary settlement in a later phase, that is, when economic circumstances changed in the third millennium BC. However, the tenure of such ancestral pastures and the duration of any associated local memories remains difficult to gauge.

\section{Pastoral Practices}

The practice of 'opportunistic stocking', in which animal numbers would have been allowed to rise well beyond the subsistence requirements of local communities, might have required relatively low investment and therefore could have been practised by relatively small scale communities. In the case of Ebla, investment in flocks could have come from the state or members of the elite who would also have to bear the cost of their administration, and to absorb any losses incurred. This would have been relatively easy for a state such as Ebla, which not only received a considerable income from trade, especially of metals, but was also in a position to benefit from the rewards of arable cropping, olive 
production and the textile industry (Bachhuber 2013, pp. 500-502; Milano 1995, p. 1226). The numbers of sheep at Ebla perhaps therefore resulted from the investment of surplus wealth into large scale livestock holdings by the royal household and other elite families. Although the cereal-based staple economy of Ebla and related cities would have provided the basic under-pinning for the economy, the wealth created by the increased connectivity and associated trade of the mid third millennium $\mathrm{BC}$ could have provided surplus for investment in livestock, and would have borne any risk of losses as well. In short, the system was sustainable as long as the vegetation resources of the steppe could be maintained.

Whether Ebla and other north Syrian cities had access to 'ancestral pastures' can only be inferred from the negative evidence for early third millennium BC settlement within the zone of uncertainty to the south and southeast. However, the occupation of the KhaburBalikh, mid Euphrates and central Syrian steppe by expanded citadel cities or geometric settlements argues for a broad and formalized process of settlement and colonization of lands that were ideal for extensive herd management.

As argued by Danti (2000), settlements in the zone of uncertainty, such as those around Tell es-Sweyhat, were probably not simply supported by a high-risk staple economy. Instead, they may have been agro-pastoral communities that profited from a combination of interregional exchange and sheep husbandry. A significant amount of the agricultural land surrounding such sites may have been devoted to fodder crops (Danti 2000; McCorriston and Weisberg 2002, p. 495), such as stubble straw, barley grain, Vicia or Lathyrus. Moreover, as noted above, sheep husbandry and barley production probably co-evolved, so that when feed supplies for flocks of sheep were insufficient, barley-based agriculture would develop and grow within the zone of uncertainty. As a result, sedentary communities would have developed both to tend the fields and to manage the flocks testified by the Ebla archives. As indicated by the growth of the modern day livestock industry, climatically marginal areas of central Syria, although not capable of supporting long-term selfsufficient sedentary settlement, are capable of producing cereal crops in many years, either to supply feed or as part of staple production, However, this operates to greatest effect when the region is connected to an appropriate wider economy.

In climatically marginal areas such as the zone of uncertainty, the inhabitants could, by adopting strategies of mobility, maintain higher total livestock populations than would be the case if herds were confined to any one climatic zone (Behnke and Scoones 1993, pp. 14-15). Adoption of such strategies would therefore result in a significant increase in the production of meat and wool. The cities of the zone of uncertainty might therefore be seen as nodes in a structured network of mobile pasturing strategies, as well as supply stations for animal feed and for travellers and trade caravans.

Although perhaps not on such a large scale as in the north, other areas also appear to have experienced a growth in activity during the fourth and third millennia BC. A case in point is the basalt region west of Homs (Philip and Bradbury 2010). Here we emphasize that such developments were not part of a broad and uniform spread of agro-pastoralism, but rather showed considerable regional variation depending upon local circumstances and opportunities.

\section{Comparisons with the Southern Levant}

As a central aim of the FCP is to consider fourth-third millennium BC settlement at a regional scale, it is appropriate to investigate the extent to which the above model of 
settlement cores and a zone of uncertainty might shed light upon developments in other regions, specifically the southern Levant (Israel and the Palestinian territories, Jordan and southern Syria/Lebanon: see Fig. 1 for site locations). This region, while not included within the primary FCP dataset, is of interest for a number of reasons:

1. In the absence of substantive data on EBA settlement in the Damascus area, the southern Levant comprises the next significant focus of EBA settlement south of Homs. Accordingly, developments there should clarify the extent to which settlement trends in western Syria sit wholly within a northern sequence of development, or share aspects of those detectable in more southerly regions.

2. EBA settlement in the region has been relatively well studied in recent decades (Esse 1991; Getzov et al. 2001; Greenberg 2002; Joffe 1993; Philip 2003, 2008), thus providing a ready dataset for comparison.

3. The Chalcolithic and EBA archaeology of the southern Levant has traditionally been studied separately from that of Syria and Mesopotamia, and communication between researchers working on the northern and southern evidence has been uneven (Prag 2009). As a result, the two regions have had rather different research priorities and assumptions. Therefore, while the differences between the material culture and the social and economic structures of the southern Levant and the Syro-Mesopotamian world during the fourth and third millennia BC have been well documented (Chesson and Philip 2003; Greenberg 2002; Joffe 1993; Philip 2008), it is worth asking whether the typological and organizational distinctions might conceal deeper structural similarities.

It is particularly appropriate to re-examine this topic now, because the long-established dataset around which the traditional accounts have grown has recently been modified by two important developments. Firstly, the 'standard' chronology of the EBA of the southern Levant has been questioned by a review of the radiometric evidence (Regev et al. 2012). The key outcomes relevant to this study are as follows:

1. The date of the EB I/II transition may vary regionally, but appears to lie close to the end of the fourth millennium BC (Regev et al. 2012, p. 558); see also Bourke et al. (2009, p. 910), who publish radiocarbon dates that place the EB IB/II transition at Pella at around 3200-3100 BC.

2. EB II, where it can be defined as a distinct phase, is relatively short, with the EB II/III transition falling around $2900 \mathrm{cal}$ BC (Regev et al. 2012, pp. 558-559).

3. The EB III period had ended by 2500 BC (Regev et al. 2012, p. 559).

In short, Late EB I (or EB IB) material falls in the later fourth millennium BC, which overlaps with the Uruk Phase (LC 5) in northern Syria (Table 1). Material assigned to traditional EB II-III should fall in the very late fourth and the first half of the third millennium BC, while material assigned to the EB IV (or Intermediate Bronze Age) could fall anywhere in the second half of the third millennium BC. The scale of this revision should come as no great surprise, as problems with the assumptions underlying the traditional chronological framework have been pointed out previously (e.g. Dessel and Joffe 2000; Philip and Millard 2000).

Another important point that arises from the revised chronology is the realization that the large EB III public buildings evidenced at sites like Khirbet Kerak and Tel Yarmouth (Greenberg et al. 2012, p. 104; de Miroschedji 1999, 2006) had probably ceased to function before $2500 \mathrm{cal} \mathrm{BC}$. As these structures and the associated walled settlements belong in the first half of the third millennium, they pre-date-by some time-the EB IV world of 
western Syria, typified by Palace G at Ebla. Therefore, the current assumption that the absence of rich burials, writing and other administrative paraphernalia from the major EBA II-III centres of the southern Levant necessarily indicates that these societies were 'less developed' than their Syrian contemporaries (e.g. Philip 2008, p. 163) is no longer tenable. Rather, the appropriate Syrian comparisons for Tel Yarmouth and Khirbet Kerak lie not in the world of Ebla as depicted in the texts from Palace G, but in the less well-documented, and we might suspect less highly-developed, pre-palace phase at Ebla (Dolce 2010) and the Ninevite V period of northwestern Iraq and northeastern Syria noted above.

In addition, we now have a refined, and well-dated, understanding of climate change in the region. This arises through a combination of high-resolution proxy climate data from Soreq Cave near Jerusalem (Bar-Matthews and Ayalon 2011), and the demonstration by Black et al. (2011, p. 18, fig. 2.5) that present-day annual rainfall is quite well correlated, within broad environmental zones, over distances of up to $100 \mathrm{~km}(\mathrm{r}=0.7)$, and moderately well correlated at up to $200 \mathrm{~km}(\mathrm{r}=0.5)$. Because a radius of $100 \mathrm{~km}$ from Soreq Cave encompasses much of that part of the southern Levant in which EBA walled settlements existed, it seems reasonable to use the Soreq Cave climate data as a framework within which to interpret EBA settlement change.

For the southern Levant, bringing the climatic and chronological data together suggests the following scenarios (see Bar-Matthews and Ayalon 2011, fig. 6):

1. EB I (late) can be equated with a gradual increase in precipitation during the latter centuries of the fourth millennium cal BC.

2. EB II-III coincides with a clearly-defined moist phase which covers most of the first half of the third millennium cal BC, peaks around $2750 \mathrm{cal} \mathrm{BC}$, and then declines back to late fourth millennium levels by $2400 \mathrm{BC}$.

3. The EB IV period coincides with a continuation of the trend towards aridity down to around $2200 \mathrm{cal} \mathrm{BC}$, followed by a short phase of even greater aridity during the last two centuries of the third millennium cal BC.

Having outlined the key changes that warrant a re-examination, we now return to the detailed evidence.

As explained by Joffe (1993, pp. 25-26), the physical affordances of the southern Levant are rather different from those of Syria. Much of Syria is covered by open agricultural plains; in contrast, the southern Levant is more complex, with zones of quite different geography and ecology located in close proximity. Fertile lowland basin lands are interspersed through a greater area of upland terrain, much of which is well-suited to horticulture, being well positioned with respect to rain-bearing westerly winds. However, the presence of these uplands means that under circumstances resembling those of the recent past, precipitation declines rapidly on the east side of the Jordan Valley, with the exception of the Hauran region of southwestern Syria. In northern Transjordan, the area receiving more than $200 \mathrm{~mm}$ annual precipitation extends no more than $50 \mathrm{~km}$ east of the River Jordan; much of it is dissected upland terrain. Further south it is closer to $25 \mathrm{~km}$ in width. In contrast to the extensive zone of uncertainty of north and west Syria therefore, the equivalent terrain in the southern Levant is much smaller, and shows marked local topographic and environmental variability (Fig. 3).

\section{The Chalcolithic}

The densest distributions of Chalcolithic settlement are in the northern Negev and the Jordan Valley (Bourke 2008, pp. 114-115; Rowan and Golden 2009, pp. 15, 27). While the 
best-known concentration of settlement is that in the northern Negev, its prominence in the literature may reflect the high surface visibility of those sites and their accessibility to excavation, perhaps itself a symptom of the collapse of this system during the early fourth millennium BC, coincident with a marked phase of aridity (Bar-Matthews and Ayalon 2011, fig. 6). In the Jordan Valley, the larger Chalcolithic sites, some of which extend over 10 ha or more, are generally located along the alluvial fans where side wadis enter the valley (Bourke 2008, pp. 114-115). While Teleilat Ghassul, located just north of the Dead Sea, was abandoned after the Chalcolithic, the larger Chalcolithic settlements further north are buried beneath substantial EBA occupations: Beth Shan and Pella are good examples (Braun 2004; Bourke 2008, p. 127). Evidence for substantial Chalcolithic occupation in the Jezreel Valley, including a settlement at Megiddo of around 7 ha (Finkelstein et al. 2006, pp. 720, 763) suggests that it too provided an important settlement core.

Chalcolithic site clusters also exist in the Irbid-Ramtha plain on the north Jordan plateau, and smaller sites are positioned along the various lesser wadi systems (Bourke 2008, p. 115). Recent fieldwork, and analysis of settlement data from the Jordan Valley and surrounding uplands (Lovell 2008; Lovell and Bradley 2011, p. 277) and the Jaulan (Bradbury 2011), suggests that upland sites, apparently associated with horticulture, were more common in the Chalcolithic than had previously been understood, although at lower intensity than in the subsequent EBA. That said, upland sites are relatively small and there is no evidence for large central sites or local settlement hierarchies (Gophna and Tsuk 2005; Rowan and Golden 2009, p. 28). The Jordan Valley is, in effect, the main settlement core for the southern Levant during the fifth millennium BC. However, Chalcolithic settlements in the Jordan Valley differ from those of the northern Fertile Crescent in several respects, including the much higher density of rural settlements in the north; the sheer bulk of the major northern sites (as described above); and in a few cases, their spatial extentfor example, the 300 ha site of Hamoukar South, which appears to have been involved in obsidian manufacture (al-Quntar et al. 2011).

\section{Later Fourth Millennium}

The probable significance of the northern lowland valleys (i.e. the Jezreel and Jordan Valleys) as a settlement core has been noted many times (e.g. Getzov et al. 2001, pp. 23-24; Joffe 1993, pp. 73-76), and it is likely that some of the larger tell sites in these areas provided chronological continuity between Chalcolithic and EB I occupations, of a kind that does not exist in the northern Negev (Braun 2004; Finkelstein et al. 2006, fig. 40.17). Less clear until very recently, however, has been the existence of a number of (possibly undefended) settlements of late fourth millennium BC date and 20-35 ha extent in the Jezreel and Jordan valleys (EB IB or late EB I in local terms) (Table 3).

While the size of some of these sites may have been exaggerated by a degree of horizontal displacement over time, the modest duration of the EB IB period (300-350 years) suggests that they should still represent major concentrations of population and economic activity. Sites of this size would be considered large during any phase of the Bronze Age in the region (Broshi and Gophna 1984, 1986), and, for that matter, in comparison to sites currently documented in Western Syria. Their presence in locations offering possibilities for floodwater irrigation (Philip 2008, pp. 170-171) places them comfortably within the category of fourth millennium BC settlement cores discussed above. The presence of facilities for capturing and storing seasonal run-off water in association with activity dating to the late fourth millennium - early third millennium BC at sites in the arid-zone, such as Jawa and Khirbet el-Umbashi (Braemer et al. 2009, 2010; 
Table 3 Large late fourth millennium BC settlements in the northern lowlands of the southern Levant

\begin{tabular}{|c|c|c|c|}
\hline Site & Location & $\begin{array}{l}\text { Estimated size during the late } 4 \text { th } \\
\text { mill. cal BC }\end{array}$ & Source of information \\
\hline $\begin{array}{l}\text { Khirbet } \\
\text { Kerak/ } \\
\text { Tel Bet } \\
\text { Yerah }\end{array}$ & North Jordan Valley & 35 ha & $\begin{array}{l}\text { Greenberg et al. (2012, } \\
\text { p. 89) }\end{array}$ \\
\hline $\begin{array}{l}\text { Tell esh- } \\
\text { Shuna } \\
\text { North }\end{array}$ & North Jordan Valley & $20-25$ ha & (Philip in prep.) \\
\hline Megiddo & Jezreel Valley & $\begin{array}{l}\text { Cited as } 45 \text { ha although the } \\
\text { combined sizes for EB I sites } \\
\text { around the tell given by the } \\
\text { Megiddo Hinterland Project } \\
\text { suggest a rather lower value }\end{array}$ & $\begin{array}{l}\text { Finkelstein et al. ( } 2006, \\
\text { p. } 763) \text {; but note rather } \\
\text { lower extent suggested on } \\
\text { pp. } 720-723\end{array}$ \\
\hline $\begin{array}{l}\text { Ain el- } \\
\text { Assawir/ } \\
\text { Tel Esur }\end{array}$ & $\begin{array}{l}\text { Northern coastal plain on } \\
\text { route leading into } \\
\text { Jezreel valley (Yannai } \\
\text { 2006, p. 280) }\end{array}$ & $\begin{array}{l}60 \text { ha late EB I artefact scatter; } \\
\text { perhaps indicative of a } 30 \text { ha } \\
\text { site }\end{array}$ & Yannai (2006, p. 2) \\
\hline
\end{tabular}

Whitehead et al. 2011), suggests that these techniques would have been a familiar aspect of settlement and community practice in the better-watered zone, although the evidence is far less likely to have been preserved.

Evidence for large-scale storage at Beth Shan (Mazar and Rotem 2009) is consistent with the suggestion (Philip 2003, pp. 107-108; Philip 2008, pp. 184-185) that power in the EBA was based upon the ability to control (i.e. to store securely and deploy strategically) agricultural products, perhaps facilitated by the growing availability of donkey transport (Milevski 2011, pp. 179-184). At the root of this lay a new emphasis upon power based on rights over the key resources of land, water and labour. New radiocarbon dates, which place the major fortified EBA structures on Tell Husn (immediately south of Pella) in the final centuries of the fourth millennium BC (Gibbins 2001; Bourke et al. 2009, pp. 908-909, table 2), would appear to indicate an increased risk of conflict, presumably the result of growing pressure on resources in the Jordan Valley at this time.

\section{Early Third Millennium}

The first few centuries of the third millennium BC (i.e. EB II-III in conventional terms) are characterized by the spread of walled settlements beyond the lowland settlement cores to encompass most of the terrain in which agriculture was possible, including the fringes of the arid zone in both the Negev and Transjordan. These sites, many of which are of modest size (4-10 ha), are often heavily fortified. Well-known EBA sites, such as Ai, north of Jerusalem, fall within this general category. A number of these sites, such as Arad in the northern Negev and Khirbet ez-Zeraqon (Kamlah 2000), Beitrawi in the Wadi Zerqa (Nigro 2011), and Bab edh-Dhra' in Transjordan (Rast and Schaub 2003), are located within the zone of uncertainty, although in these cases, activity appears to be underpinned by water management techniques. We suggest therefore that one aspect of the expansion of walled settlements across the southern Levant during the first half of the third millennium $\mathrm{BC}$, was the first large-scale occupation of the zone of uncertainty by communities practising intensive agriculture. 
The growth of substantial settlements at the previously sparsely-settled northern sites of Tel Dan and Hazor during EB II (Greenberg 2002, p. 35) may also form part of this general intensification of landscape usage, while a comparable process is documented in southern Syria, where the Hauran shows a clear increase in settlement and the appearance of small walled centres (usually $<4$ ha in size) during EBII-III (Criaud and Rohmer 2010, p. 52). In fact, Khirbet ez-Zeraqon in northern Transjordan and Labwe in southern Syria (Braemer et al. 2010) both show evidence of substantial planning and appear to represent variations upon what Douglas (2011, p. 6) has termed the 'single-main-period site'. Taken as a whole, these sites appear to stress defence, storage of agricultural produce, and water security (Braemer et al. 2009; Douglas 2011; Philip 2008, Nigro 2011).

While the occupational sequences differ between individual sites and regions, with each case reflecting specific local environmental and socio-political conditions (e.g. Dessel and Joffe 2000; Greenberg 2002, 2003; Nigro 2011), these differences should not cloud our view of the overall process. In light of evidence for increased precipitation in the earlier third millennium BC (Bar-Matthews and Ayalon 2011), and the absence of significant Middle or Late Bronze Age activity at many of these locations, the expansion of walled settlements beyond the lowland basin cores may represent an opportunistic response to increasing precipitation, which by permitting an intensification of agricultural production increased the possibilities for the collection and control of agricultural products by incipient elites. In fact, the appearance of substantial public architecture during EB II-III at the larger walled settlements such as Tel Yarmouth and Khirbet Kerak (EB III) (de Miroschedji 1999, 2006; Greenberg et al. 2012, pp. 101-102; Mazar 2001) might indicate that the emergence of elites was focused upon a limited number of larger regional centres.

The Jordan Valley itself witnessed an interesting set of developments around the end of the fourth millennium BC. While sites such as Khirbet Kerak, Tell Abu al-Kharaz, and Pella were fortified (Bourke et al. 2009; Fischer 2008, p. 345; Gibbins 2001; Greenberg et al. 2012, pp. 92-93), others such as Tell esh-Shuna and Beth Shan appear to have undergone either temporary abandonments or marked reductions in activity (Mazar 2012, pp. 23-24). The broad contemporaneity of decline at some sites, and the construction of fortifications at others is consistent with a period of competition for resources between the large EB I centres in the north Jordan Valley. The outcome, it would appear, was that some communities came to control land that had previously been worked by others (e.g. Tell eshShuna, Beth Shan). The reoccupation of the latter sites appears to be marked by the presence in quantity of the distinctive Khirbet Kerak ware (KKW), a class of ceramics probably to be associated with the settlement of people with a habitus quite distinct from that of the local EB II-III population, and with clear connections to more northerly regions (Greenberg 2011; Iserlis 2009; Zuckerman et al. 2009). However, at other sites, such as Khirbet Kerak itself, KKW occurs alongside 'local' ceramic forms (Greenberg et al. 2012, p. 102).

While KKW was traditionally ascribed to EB III, the revised chronology discussed above places this development around $2900 \mathrm{cal} \mathrm{BC}$, that is, not long after the demise of the late EB I occupations at Shuna and Beth Shan and the construction of the first fortifications at Khirbet Kerak and Pella (Bourke et al. 2009; Greenberg et al. 2012, p. 90). The appearance of quantities of KKW stratified above deposits containing typical late EB I material might therefore indicate that the surviving polities in the Jordan Valley sought to revive agricultural production by introducing immigrants who would work the land but (unlike the previous inhabitants) would have no direct claim to its ownership. Seen in this light, the settlement of populations using KKW in the Jordan Valley, and the expansion of walled settlements across hitherto lightly occupied zones in the early third millennium BC, 
might be seen as context-specific responses to the same need, that of increasing agricultural production.

The main exception to the above developments is in the central coastal plain, which was lightly occupied during EB II-III. As Faust and Ashkenazy (2009) argue, this may reflect the negative impact of increased precipitation upon the habitability of a poorly-drained region. This suggestion draws support from evidence showing an increase in the extent of marsh vegetation around Ain el-Assawir during the centuries leading up to the abandonment of the site towards the end of the Late EB I period (Horowitz 2006, p. 268).

\section{Early Bronze IV}

In the southern Levant, the EB IV period (now re-dated to the second half of the third millennium BC) witnessed the virtual abandonment of large defended sites. However, in contrast to the image of invading pastoralists put forward by Kenyon (1966, 1979, pp. 119-147), it is clear that the area saw continued sedentary occupation in the form of small agro-pastoralist communities operating a subsistence economy (Prag 1974; Palumbo 1991; Mazar 2006, pp. 116-115): 'Ein el-Hilu in the Jezreel is one example (Covello-Paran 2009).

According to the revised chronology, many walled EB II-III settlements would have been abandoned by 2500 BC. However, the Soreq Cave evidence (Bar-Matthews and Ayalon 2011) suggests that precipitation around 2500-2400 cal BC, while some way below the peak value of the early third millennium, was still higher than in the late fourth millennium cal BC. While the incision of wadi systems as a result of greater water power in the early third millennium BC may have rendered floodwater irrigation difficult in some areas (Donahue 2003; Rosen 1995) this cannot provide a universal explanation for the decline.

A marked decline in settlement in the southern Levant during EB IV is in clear contrast to the situation in north and west Syria outlined above, where decline occurred primarily during the final quarter of the third millennium BC (McMahon 2012, pp. 664-667; Kuzucuoğlu and Marro 2007; Wossink 2009). However, survey data from southern Syria suggest that during EB IV the region witnessed both a reduction in site numbers and a shift to small agro-pastoral settlements generally less than 1 ha in size (Criaud and Rohmer 2010, p. 56, fig. 6). The Beq'a Valley also saw a substantial reduction in settlement numbers from EB II-III to EB IV, although in this area, EB IV settlement was focused on a subset of those tells which had been occupied during EB II-III (Marfoe 1995, p. 98; Marfoe 1998, pp. 154-155). During EB IV, both the Hauran and the Beq'a appear to demonstrate changes in settlement more akin to those seen in the southern Levant than those of western Syria.

We suggest that the collapse of the walled centres of the southern Levant by $2500 \mathrm{cal}$ $\mathrm{BC}$ came about through a combination of factors. Firstly, the documented decrease in rainfall during the second quarter of the third millennium would have slowly diminished the possibility of creating agricultural surpluses. This would have been exacerbated by the number of walled settlements that were located in the zone of uncertainty, while the importance of hydrological management at many EB II-III sites (Philip 2008, pp. 170-171) underscores its role in ensuring the long-term viability of at least some of these communities.

The second factor is the absence, from the southern Levant, of a local equivalent to the large and hitherto under-exploited northern zone of uncertainty characteristic of much of Syria. Not only did the southern Levant offer a 'zone' that was much smaller than that of 
Syria (Fig. 3b), but because of the successful expansion during the earlier third millennium $\mathrm{BC}$, the prime niches and key wadi systems within this zone had already been occupied. The southern landscape, therefore, simply could not offer the kind of new opportunities that were available in the 'pristine' steppe landscape of Syria.

Moreover, the Syrian steppe formed an important communications route between western Syria, the Euphrates Valley, and North Mesopotamia, as witnessed by the interactions described in the Ebla texts (Archi and Biga 2003). In the case of the southern Levant, despite the growing evidence for pastoral nomadic activity in the steppe regions of Jordan during the Chalcolithic-EBA, perhaps connected to the acquisition of resources such as flint (Abu Azizeh 2011, 2013; Müller-Neuhof 2006; Quintero et al. 2002), there was no major political entity at the eastern side of the steppe with whom to interact, and so the value of the steppe as a network of communication between competing polities was markedly reduced. Equally, the large distances between EBA polities of the southern Levant and those developing in Syria, and the clear orientation of the political relations of Ebla towards the north and east (Biga 2008), suggest that southern polities would have struggled to develop the kind of political and economic relationships that could have driven and sustained competitive interactions of the kind documented between Syrian polities.

Thus the explanation for the inability of centres like Tel Yarmouth and Khirbet Kerak to make the transition to polities equivalent to those of EB IV Syria may lie in a combination of declining rainfall, the limited size of agricultural plains, and the absence of an underexploited zone of uncertainty. The lack of the last named would have deprived elites in southern communities of the substantial additional (pastoral) resources necessary to support the increase in the scale and complexity of major polities that is evident in Syria from $2500 \mathrm{BC}$ onwards. The apparently rapid collapse of the southern polities may reflect the impact on a finely balanced system of a relatively moderate reduction in precipitation, which nevertheless undermined the intensive agricultural model upon which the regional economy was based. In turn, the absence of an extensive zone of uncertainty meant that this could not be circumvented by developing new modes of economic activity.

It is probably not by chance that the best example of a site which maintained its walled status into EB IV is Khirbet Iskander in Transjordan. This site was located on a major perennial wadi (Cordova and Long 2010, pp. 30-31) and in a region in which it would have been difficult to attain the levels of complexity posited for EB II-III communities in more northerly and western regions (Philip 2008, p. 210; Richard and Long 2009). As a result, Iskander-and perhaps other communities in similar locations-was able to adjust more readily to the new circumstances than its more developed counterparts in the northern and western regions of the southern Levant. The similarity of EB IV developments in other variegated, spatially constrained environments, such as the Beq'a, Homs basalt and Hauran, to the situation in Israel, the Palestinian territories and Transjordan may well reflect the limited zone of uncertainty in those areas too.

This reconstruction has interesting implications for our understanding of social and economic developments in the EB IV period, and its distinctive material culture. Bunimovitz and Greenberg (2006) have described the way in which scholarly views on the EB IV period have followed shifting paradigms in wider disciplinary thinking. For example, studies in the 1980s (Dever 1980; Richard 1980) emphasized the strong connection of EB IV ceramics to those of the local EB III. As a result, the evidence for the adoption of items of material culture of Syrian inspiration, including those ceramic and metal forms that had shaped Kenyon's concept of 'Amorite' invaders (e.g. Kenyon 1966) were somewhat underplayed. More recently, both Bunimovitz and Greenberg (2004) and Prag (2009) have noticed that those EB IV ceramic forms which suggest connections with Syria appear 
linked to the consumption of food and drink, while metal forms mostly take the form of weapons or personal ornaments, and generally occur in graves. Taken together these features hint at the adoption, in the south, of some of the material culture items that were associated with practices of burial and status-marking documented in EB IV Syria (Archi 2012, pp. 20-24), and perhaps some aspects of the associated systems of representation.

Building on the discussion above, we suggest that one result of the disappearance of the EB II-III walled centres in the southern Levant would have been a decline of the systems of representation associated with that particular social and economic order. On the other hand, knowing the importance of livestock raising, and wool in particular, to Syrian centres such as Ebla, we suggest that the EB IV agro-pastoral communities of the southern Levant may, at least peripherally, have been involved in the resourcing or seasonal management of the vast animal herds that occupied the rangelands of the Syrian steppe in EB IV. While this may have involved the supply of young animals, or breeding stock, there may also have been a demand for significant quantities of human labour. In this light, the apparent contradiction between the clear derivation of the bulk of the EB IV ceramic repertoire of the southern Levant from local EB III forms (Richard 1980; D'Andrea 2012) and the adoption of a very specific subset of Syrian material culture by the same communities becomes comprehensible. This occurs through a situation characterized by Bunimovitz and Greenberg (2006, p. 29) as one of 'semi-nomadic pastoralists perhaps straddling the interface between Canaan and the urban centres of central Syria'. It is noteworthy that the first appearance in southern Syria of ceramic forms that are of clear northern derivation, such as decorated goblets, occurs within EB IV assemblages at Moumassakhin north of Damascus, and the Hauran (Braemer 2002, p. 15). Together, these hint at an increase in the extent of communications across the steppe running southwards from Tadmor (Palmyra) and the Homs region to Damascus, the Hauran, and ultimately the southern Levant, and underscores the importance of connectivity—fueled by animal herding — to shaping societies across the region in the later third millennium BC.

Of particular interest in this regard is the presence of a 'gap' at Sahl al-Mafid, the southernmost point on the Très Long Mur, which gave access to a depression running between the Anti-Lebanon and Palmyrid ranges and offered a convenient route for the movement of animals to and from Damascus (Geyer et al. 2010, p. 64, fig. 10). This suggests the emergence of new, south-facing, networks of communication. In the absence of significant southern power centres during EB IV, such a process would presumably reflect the gradual reorientation of communities in the southern Levant towards a northern sphere, through the opportunities offered by this new and physically distant core.

\section{Discussion and Conclusions}

Our review of the development of fourth and third millennium BC settlement using key sample areas drawn from the northern Fertile Crescent has indicated the existence of several distinctive settlement structures and diachronic trajectories (Table 4). Within the northern Fertile Crescent, evidence from the Khabur plains suggests that both site morphology and the demographic context of the fourth and third millennium phases of urbanization were very different. Whereas most of the largest LC settlements grew within a moderately dense matrix of rural settlement, those of the mid-late third millennium grew in both densely settled and sparsely populated areas. Moreover, in contrast with the gradual growth and decline of the major LC centres, towns of the third millennium exhibited a rapid arc of growth, followed by a crest and then decline. The quantified evidence for the 


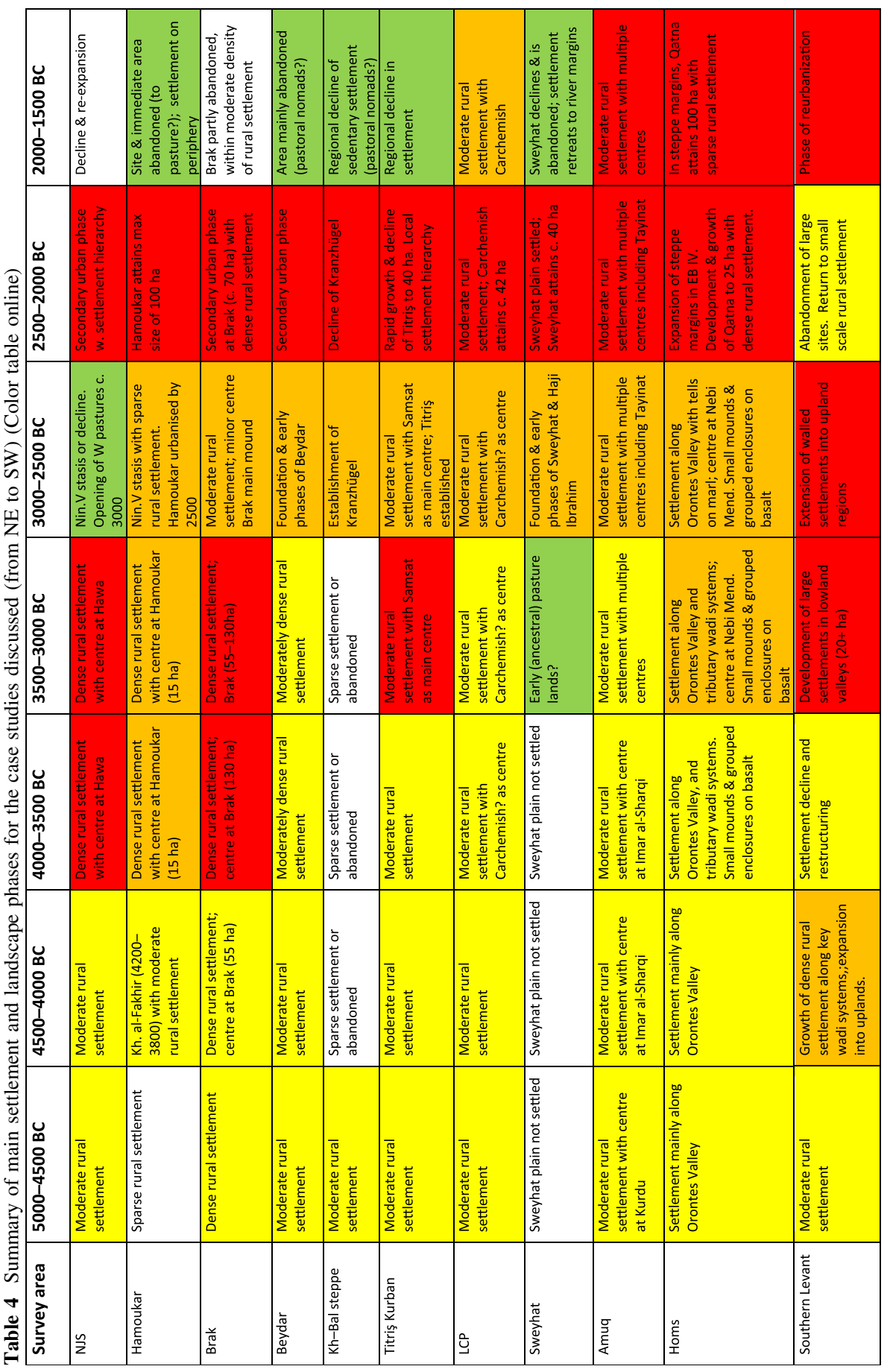


development of Late Chalcolithic centres presented above supports earlier models of ancient urbanism, such as those of Boserup (1983, pp. 63-75), which suggest that the earliest urbanism developed within areas of dense settlement and population (Klasen and Nestmann 2006, p. 612). However, that this was not the only context for early urbanization is indicated by the growth of third millennium citadel cities and Kranzhügel sites, which developed in both densely and sparsely settled regions.

Because the floruit of citadel cities and related expanded settlements was brief, these cannot be regarded as the normal class of long-term settlement in the northern Fertile Crescent. Overall, small and medium sized communities underpinned long-term settlement throughout the region. Although some of these small tells may have been relatively shortlived 'towers', perhaps equivalent to the dimtu east of the Tigris or the Bàd-3 of the Ebla texts (Sebastien Rey pers. comm. 2012), archaeological surveys suggest that many were remarkably long-lived, as was the case for numerous sites in the Middle Euphrates or Orontes valleys, which often show a settlement record spanning as much as 7000 years (Wilkinson et al. 2012). Whatever the precise mechanisms for their development and survival, it seems that the second phase of EBA urbanization exhibited at least two dynamics: first, a relatively stable pattern of small tells that persisted for centuries or millennia (Fig. 21); and second, 'boom and bust' settlements that frequently grew around a pre-existing mound, reached a maximum size and then, within usually a few centuries, collapsed down to a basic small unit, usually around the original tell.

Within the densely populated Khabur region, pastoral needs were apparently catered for either by enclosed enclaves such as that described for the Hamoukar/Hawa areas (above), or by existing open spaces, such as in perhaps the Wadi Radd headwaters or basalt uplands like those near Tell Beydar. In contrast, in the Khabur-Balikh steppe and the Middle Euphrates, previously open lands in the zone of uncertainty were perhaps adopted for opportunistic stocking and related agro-pastoral strategies and were ultimately 'colonized'

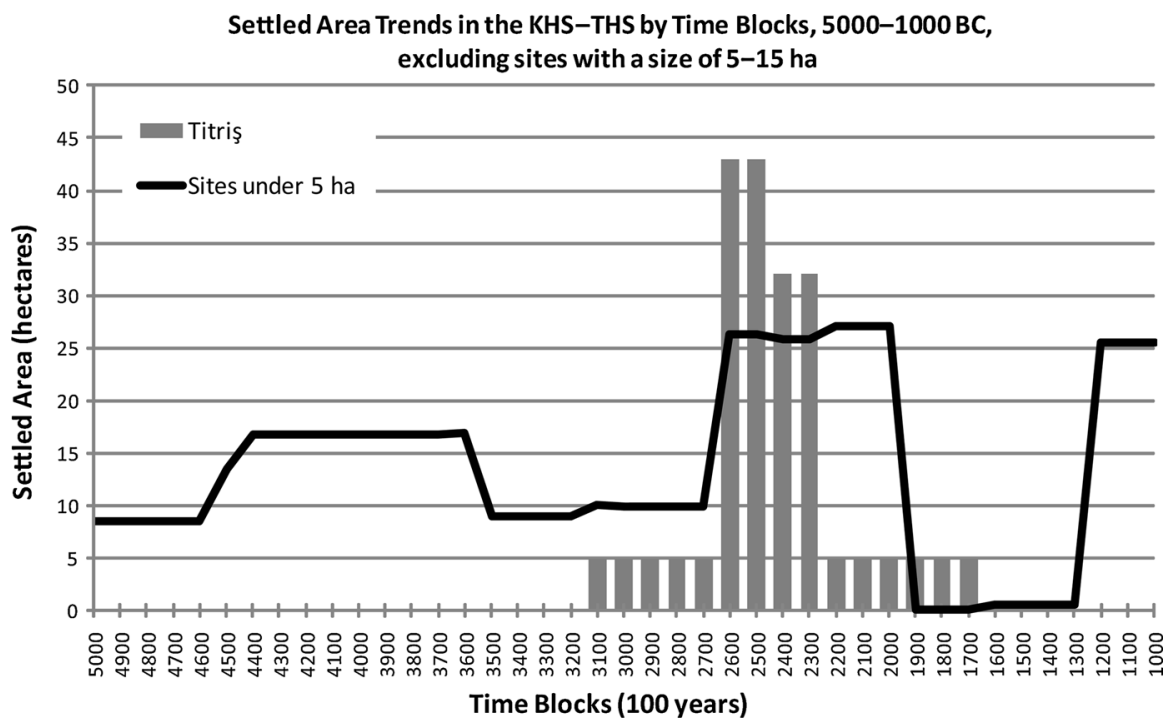

Fig. 21 Aggregate area of small sites ( $<5 \mathrm{ha}$ ) compared with the area of Titriş Höyük, giving an impression of the sustainable nature of small settlements versus the 'boom and bust' nature of the citadel city 


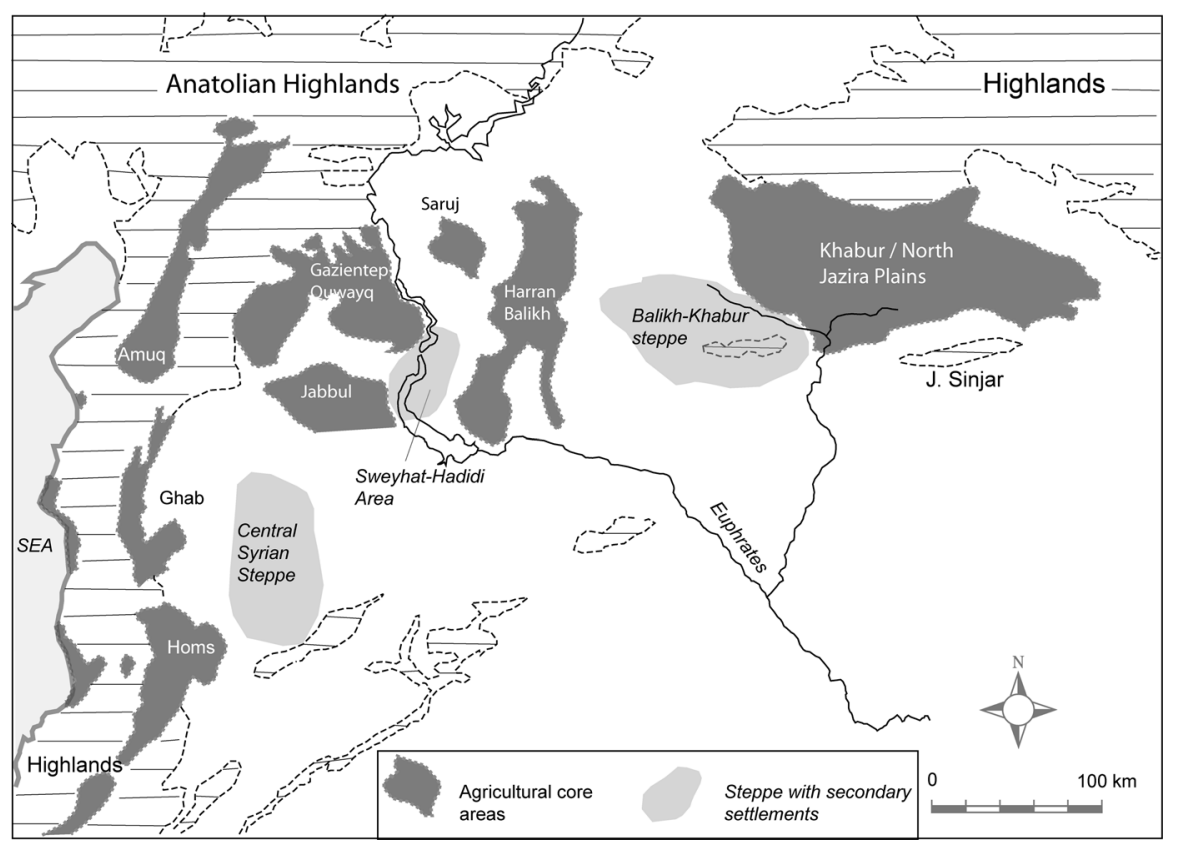

Fig. 22 Agricultural cores and zones of secondary settlement in Syria and neighbouring areas

by a range of expanded sites during the first half of the third millennium BC. A similar argument can also be made for the central Syrian steppe, but somewhat later, during EB IV (Geyer et al. 2007). Because communities in such semi-arid lands cannot be supported by conventional rain-fed staple-based production, we argue that aggrandizing states such as Ebla adopted high-risk livestock production in tandem with rain-fed barley production to support a large-scale agro-pastoral economy. This resulted in the extension of settlement into the marginal steppe lands of central Syria, in part to service the needs of livestock management but also to secure the important networks of communication (Fig. 22). In contrast, in the southern Levant such settlement appears to have been inhibited both because the local zone of uncertainty was less extensive than in Syria, and because much of it had already been occupied as part of an intensification of agricultural activity during the early third millennium BC, and so could not offer the opportunities for large-scale agropastoral settlement that were available in the northern Fertile Crescent. In the southern Levant, reorientation towards northern networks, as demonstrated by the elements of Syrian material culture described above, took place only following the demise of the local polities around $2500 \mathrm{BC}$.

Although such extensions into the steppe may have resulted from the policies of aggrandizing states, not all parts of the region can be regarded as the domain of elites or royal households and within the penumbra of state development. Although similar agropastoral economies may have persisted, their impact on the landscape would have been different. For example, the basalt region west of Homs shows a rather different landscape signature from that of central and northern Syria, one which reflects a local small-scale shift in agro-pastoral practice but still designed to take advantage of land with good grazing potential. 
The interactions between agricultural cores, opportunistic agro-pastoralism and connectivity allow the following conclusions to be drawn for the Early Bronze Age landscape of the northern Fertile Crescent:

- The zone of uncertainty, together with sub-optimal zones, provided productive economic niches, as long as certain conditions prevailed, and the scale of the economic system was such that there was sufficient 'insurance' in place to buffer some of the risks and uncertainties. In other words, the size of the regional polity modifies the risk. Developments in these areas were probably linked to wider economic structures, and may well reflect growing connections with more prosperous regions.

- Risk, and perceptions of uncertainty, can play an important role in the development of agrarian practices-no single model can be applied to these landscapes. Herding practices can vary and be adopted in different ways depending upon local circumstances.

- Any increase in the numbers of sheep may require a commensurate increase in the amount of feed, because the large flocks that arguably prevailed during parts of the EBA could not necessarily have been provisioned from pastures alone, hence the increase in evidence for fodder crops in the third millennium BC (Van Lerberghe 1996, p. 121; McCorriston and Weisberg 2002, p. 495). In fact, the observation that traditionally, during dry years, sheep can graze 'failed' cereal crops (Nordblom 1983) demonstrates that in agro-pastoral lands there is no sharp division between sedentary cultivation and pastoralism.

- A significant proportion of the Kranzhügel sites and citadel cities, which have come to be viewed as characteristic of North Mesopotamia and northern Syria in the third millennium BC appear to have developed in the context of a temporally restricted phase of agro-pastoral activity in the zone of uncertainty, a point which explains both their prominence in the landscape and the accessibility of EBA deposits to archaeology.

- However, many others, including the largest sites in the 80-120 ha range, developed within the moister zone, in which settlement was more sustainable. These sites, although developed in densely settled areas, again showed a rather abbreviated trajectory of growth and decline from a pre-existing minor tell of 300-500 years duration (Pfälzner 2010; Danti and Zettler 2007).

- Connectivity must have been a key factor in the development of the settlement and economic landscape of the Fertile Crescent. This is particularly significant for the growth of urban-scale settlements which, arguably, were both centres of innovation and nodes for the transmission of ideas (Pumain et al. 2009; Matney 2012, p. 574). Not only do the patterns of hollow ways suggest that both local and inter-regional connections underpinned early urbanization, the considerable width of these features argues in favour of their having been drove roads for large numbers of sheep and goats (Wilkinson et al. 2010; Casana 2013).

It also follows that the agro-pastoral communities of the zone of uncertainty during the later third millennium $\mathrm{BC}$ put in place the foundations-economic, socio-political and symbolic-for the Amorite states that followed during the early second millennium, which are well represented in the Mari letters (Fleming 2004; Porter 2012). However, the fragile practices within the zone of uncertainty would only have persisted as long as rainfall was sufficient for flocks to be fed and barley to be grown, or while the resources of the royal household or state could provide a buffer. Rainfall variations probably had different impacts in different regions of the Fertile Crescent. In climatically marginal areas of the north, not only did large settlements grow up rapidly, but some appear to have grown 
during periods of increased rainfall, whereas others, such as Tell es-Sweyhat, apparently grew and declined during phases when the data from both Van and Soreq (Lemcke and Sturm 1997; Bar-Matthews and Ayalon 2011) suggest that rainfall was declining. Within the moister parts of the Khabur plains, the relationship between settlement growth or decline and climate change is also unclear (Zettler 2003; Pfälzner 2010; McMahon 2012, pp. 664-667). These examples suggests that the relationship between climate and settlement growth was not necessarily linear. The complexity of human-climate relations is also mentioned by Riehl (2012, p. 119), who suggests that differences in eco-geography, as well as the political and cultural composition of a population, may have caused the effects of climatic change on human populations to be very diverse (and these effects may themselves have interacted in complex ways). Such complexities seem to have been in operation throughout the southern Levant and Fertile Crescent, and specifically within the zone of uncertainty, where the strength and spatial extent of states may have changed not only the perceptions of risk, but also the way that elites or their clients were able to wrestle with or override climatic fluctuations. If rainfall diminished significantly, trade patterns were disrupted, or the resources of the state were reduced, then high-risk agropastoralism within the zone of uncertainty would have become less attractive and the area would have been abandoned. In contrast, the sustainable zone in the north and northwest would not have participated to the same degree in the high-risk/high-profit economies of the zone of uncertainty. Overall, it appears that the structured agro-pastoral strategies that prevailed during the late third millennium BC within the zone of uncertainty may have paved the way for the rather different pastoral and sedentary communities of the Amorites and the Mari letters, a point which we plan to revisit in detail in a future article.

Acknowledgments We are very grateful to the following for providing fundamental support for the research: the Arts and Humanities Research Council (AHRC), grant number AH/F010095/1, for a major grant to the FCP; the Council for British Research in the Levant and the British Academy for funding the fieldwork elements of the Settlement and Landscape Development in the Homs Region (SHR) and Land of Carchemish Projects; and The Leverhulme Trust (Grant F00128/AR: The Vanishing Landscape of Syria), which supported analysis of the data from SHR. Thanks also go to Durham University and its Department of Archaeology for sponsoring the Informatics Laboratory which was crucial for the analyses presented here. Our colleagues from the FCP: Emma Cunliffe, Michelle de Gruchy, and Louise Rayne also deserve thanks for discussion and input, as well as Jason Ur, for data on the Hamoukar region. We also wish to thank the relevant departments of antiquities in Syria, Iraq and Turkey, and the directors of the named projects discussed in the text for providing the support for the original surveys. In Syria, the SHR and Land of Carchemish Projects benefitted significantly from permissions, help, and advice supplied by the Directorate of Antiquities and Museums in Damascus, Aleppo and Homs. We specifically wish to thank Dr Bassam Jamous, Director, Directorate General of Antiquities and Museums and Dr Michael alMaqdissi, Director of Excavations, Directorate General of Antiquities and Museums, for graciously facilitating fieldwork in the areas of Homs and Carchemish. We are also grateful to Drs Nadim Fakesh, Sa'ir Yarta and Yusuf Kanjo and Mr Mohammed Ali in Aleppo, who gave their continued support to the Land of Carchemish Project, and to our Syrian collaborators Farid Jabbour, Maryam Bachich and their colleagues in the Homs office of the DGAM, for their active involvement in SHR. Many thanks to the anonymous reviewers for providing helpful comments, and to the editors, Timothy Taylor and Sarah Wright, for their assistance throughout the editorial process. The Fragile Crescent Project data used in this article is available from the authors.

Open Access This article is distributed under the terms of the Creative Commons Attribution License which permits any use, distribution, and reproduction in any medium, provided the original author(s) and the source are credited. 


\section{References}

Abu Azizeh, A. (2011). Structures cultuelles et funéraires des IV et $\mathrm{III}^{\mathrm{e}}$ millénaires dans le sud jordanien désertique: L'occupation de la région d' al-Thulaythuwat. In T. Steimer-Herbet (Ed.), Pierres levées, stèles anthropomorphes et dolmens [Standing stones, anthropomorphic stelae and dolmens] (pp. 21-39). Oxford: BAR (International Series 2317)/Lyon: Maison de 1'Orient et de la Méditerranée Jean Pouilloux.

Abu Azizeh, A. (2013). The southeastern Jordan's Chalcolithic_Early Bronze Age pastoral nomadic complex: Patterns of mobility and interaction. Paléorient, 39, 149-176.

Adams, R. Mc C. (1981). Heartland of cities. Chicago: University of Chicago Press.

Adams, R. Mc C. (2006). Shepherds at Umma in the Third Dynasty of Ur: Interlocutors with a world beyond the ordered field of scribal vision. Journal of the Economic and Social History of the Orient, 49(2), $133-169$.

Akkermans, P. M. M. G. (1993). Villages in the steppe. Ann Arbor: International Monographs in Prehistory.

Akkermans, P. M. M. G., \& Schwartz, G. M. (2003). The archaeology of Syria: From complex huntergatherers to early urban societies (ca. 16,000-300 BC). Cambridge: Cambridge University Press.

Algaze, G. (1993). The Uruk world system: The dynamics of expansion of early Mesopotamian civilization. Chicago: University of Chicago Press.

Algaze, G. (1999). Trends in the archaeological development of the Upper Euphrates Basin of southeastern Anatolia during the Late Chalcolithic and Early Bronze Ages. In G. del Olmo Lete \& J.-L. Montero Fenollós (Eds.), Archaeology of the Upper Syrian Euphrates: The Tishrin dam area. Aula Orientalis Supplement 15 (pp. 535-572). Barcelona: Editorial Ausa.

Algaze, G. (2001). Initial social complexity in southwestern Asia: The Mesopotamian advantage. Current Anthropology, 43, 199-233.

Algaze, G. (2008). Ancient Mesopotamia at the dawn of civilization. Chicago: University of Chicago Press.

Algaze, G. (2012). Titriş Höyük: The nature and context of third millennium B.C.E. urbanism in the Upper Euphrates Basin. In S. R. Steadman \& G. McMahon (Eds.), The Oxford handbook of ancient Anatolia: 10,000-323 B.C.E (pp. 993-1011). Oxford: Oxford University Press.

Algaze, G., Dinckan, G., Hartenburger, B., Matney, T., Pournelle, J., Rainville, L., et al. (2001). Research at Titriş Höyük in southeastern Turkey: The 1999 season. Anatolica, 27, 1-84.

Algaze, G., Misir, A., \& Wilkinson, T. J. (1992). Şanliurfa Museum/University of California excavations and surveys at Titriş Höyük 1991: A preliminary report. Anatolica, 18, 1-60.

Allentuck, A. (2004). Production, distribution and consumption of animals at Early Bronze Age Titriş Höyük, southeastern Turkey: A zooarchaeological approach. Unpublished MA Thesis, University of Manitoba.

al-Maqdissi, M. (2007). Notes d'archéologie levantine X. Introduction aux travaux archéologiques syriens à Mishrifeh/Qatna au nord-est de Homs (Emèse). In D. Morandi Bonacossi (Ed.), Urban and natural landscapes of an ancient Syrian capital: Settlement and environment at Tell Mishrifeh/Qatna and in central-western Syria. Proceedings of the international conference held in Udine, 9-11 December 2004 (pp. 19-27). Udine: Forum Editrice 1.

al-Maqdissi, M. (2010). Matériel pour l'étude de la ville en syrie (deuxième partie): Urban planning in Syria during the second urban revolution (mid third millennium BC). In K. Ohnuma (Ed.), Formation of tribal communities. Integrated research in the Middle Euphrates, Syria (pp. 131-146). Special Issue of al-Rāfidān. Hiroshima: LetterPress Co.

al-Quntar, S., Khalidi, L., \& Ur, J. (2011). Proto-urbanism in the late 5th millennium BC: Survey and excavations at Khirbet al-Fakhar (Hamoukar), Northeast Syria. Paléorient, 37(2), 151-175.

Andersson, E., Felluca, E., Nosch, M. L., \& Peyronel, L. (2010). New perspectives on the Bronze Age textile production in the eastern Mediterranean: The first results with Ebla as the pilot study. In P. Matthiae, N. Marchetti, L. Nigro \& F. Pinnock (Eds.), Proceedings of the 6th annual congress on the archaeology of the ancient Near East, May 5th-10th 2008, 'La Sapienza'-Università di Roma (Vol. 1, pp. 159-176). Wiesbaden: Harrasowitz.

Archi, A. (1990). Agricultural production in the Ebla region. Les Annales Archéologiques Arabes Syriennes, $40,51-55$.

Archi, A. (2011). In search of Armi. Journal of Cuneiform Studies, 63, 5-34.

Archi, A. (2012). Cult of the ancestors and funerary practices at Ebla. In P. Pfälzner, H. Niehr, E. Pernicka \& A. Wissing (Eds.), (Re-) Constructing funerary rituals in the ancient Near East: Proceedings of the first international symposium of the Tübingen Post-Graduate School 'Symbols of the Dead' in May 2009. Qatna Studien Supplementum 1 (pp. 5-31). Wiesbaden: Harrassowitz.

Archi, A., \& Biga, M. G. (2003). A victory over Mari and the fall of Ebla. Journal of Cuneiform Studies, 55 , 1-44. 
Bachhuber, C. (2013). Sumer, Akkad, Ebla and Anatolia. In H. Crawford (Ed.), The Sumerian world (pp. 498-516). London: Routledge.

Ball, W., Tucker, D., \& Wilkinson, T. J. (1989). The Tell al-Hawa Project: Archaeological investigations in the north Jazira 1986-87. Iraq, 51, 1-66.

Bar-Matthews, M., \& Ayalon, A. (2011). Mid-Holocene climate variations revealed by high-resolution speleothem records from Soreq Cave, Israel and their correlation with cultural changes. Holocene, 21(2), 163-172.

Behnke, R. H., \& Scoones, I. (1993). Rethinking rangeland ecology: Implications for rangeland management in Africa. In R. H. Behnke \& I. Scoones (Eds.), Rangeland ecology at disequilibrium: New models of natural variability and pastoral adaptation in African savannas. London: Overseas Development Institute.

Biga, M. G. (2008). Au-delà des frontières: Guerre et diplomatie à Ebla. Orientalia, 77(4), 289-334.

Biga, M. G. (2010). Textiles in the administrative texts of the royal archives of Ebla (Syria, 24th Century BC) with particular emphasis on coloured textiles. In C. Michel \& M.-L. Nosch (Eds.), Textile terminologies in the ancient Near East and Mediterranean from the third to the first Millennia BC (pp. 146-172). Oxford: Oxbow.

Black, E., Hoskins, B., Slingo, J., \& Bradshaw, D. (2011). The present-day climate of the Middle East. In S. J. Mithen \& E. Black (Eds.), Water, life and civilisation: Climate, environment and society in the Jordan Valley (pp. 13-24). Cambridge: Cambridge University Press.

Boese, J. (1995). Ausgrabungen in Tell Sheikh Hassan I. Saarbrücken: Saarbrücker Druckerei und Verlag.

Boserup, E. (1983). Population and technology. Oxford: Blackwell.

Bourke, S. J. (2008). The Chalcolithic period. In R. Adams (Ed.), The archaeology of Jordan: A reader (pp. 109-160). London: Equinox.

Bourke, S. J., Zoppi, U., Meadows, J., Hua, Q., \& Gibbins, S. (2009). The beginnings of the Early Bronze Age in the North Jordan Valley: New ${ }^{14} \mathrm{C}$ determinations from Pella in Jordan. Radiocarbon, 51(3), 905-913.

Bradbury, J. (2011). Landscapes of burial? The Homs basalt, Syria in the 4th-3rd millennia BC. PhD thesis, Dept of Archaeology, Durham University.

Bradbury, J., \& Philip, G. (2011). The world beyond the tells: Pre-classical activity in the basalt landscape of the Homs region, Syria. In T. Steimer-Herbet (Ed.), Pierres levées, stèles anthropomorphes et dolmens [Standing stones, anthropomorphic stelae and dolmens] (pp. 169-179). Oxford: BAR (International Series 2317)/Lyon: Maison de l'Orient et de la Méditerranée Jean Pouilloux.

Braemer, F. (2002). La céramique du Bronze ancien en Syrie du sud. In M. al-Maqdissi, V. Matoïan \& C. Nicolle (Eds.), Céramique de l'âge du bronze en Syrie 1: La Syrie du sud et la vallée de l'Orontes. Bibliothèque archéologique et historique 161 (pp. 9-21). Beirut: Institut français d'archéologie du Proche-Orient.

Braemer, F., Genequand, D., Dumond Maridat, C., Blanc, P.-M., Dentzer, J.-M., et al. (2009). Long-term management of water in the Central Levant: The Hawran case (Syria). World Archaeology, 41(1), 36-57.

Braemer, F., Geyer, B., Castel, C., \& Abdulkarim, M. (2010). Conquest of new lands and water systems in the western Fertile Crescent (central and southern Syria). Water History, 2(2), 91-114.

Braidwood, R. J. (1937). Mounds in the Plain of Antioch. Chicago: Oriental Institute.

Braun, E. (2004). Early Beth Shan (strata XIX-XIII): G. M. Fitzgerald's deep cut on the tell. Philadelphia: University of Pennsylvania Museum of Archaeology and Anthropology.

Bridgland, D. R., Westaway, R., Romieh, M. A., Candy, I., Daoud, M., Demir, T., et al. (2012). The River Orontes in Syria and Turkey: Downstream variation of fluvial archives in different crustal blocks. Geomorphology, 165, 25-49.

Broshi, M., \& Gophna, R. (1984). The settlements and population of Palestine during the Early Bronze Age II-III. Bulletin of the American Schools of Oriental Research, 253, 41-53.

Broshi, M., \& Gophna, R. (1986). Middle Bronze Age II Palestine: Its settlements and population. Bulletin of the American Schools of Oriental Research, 261, 73-90.

Brustolon, A., \& Rova, E. (2007). The Late Chalcolithic period in the Tell Leilan region: A report on the ceramic material of the 1995 Survey. Kaskal (Rivista di storia, ambienti e culture del Vicino Oriente Antico), 4, 1-42.

Bunimovitz, S., \& Greenberg, R. (2004). Revealed in their cups: Syrian drinking customs in intermediate Bronze Age Canaan. Bulletin of the American Schools of Oriental Research, 334, 19-31.

Bunimovitz, S., \& Greenberg, R. (2006). Of pots and paradigms: Interpreting the Intermediate Bronze Age in Israel/Palestine. In W. G. Dever, S. Gitin, J. E. Wright, \& J. P. Dessel (Eds.), Confronting the past: Archaeological and historical essays on ancient Israel in honor of William G. Dever (pp. 23-31). Winona Lake, IN: Eisenbrauns.

Burghardt, A. F. (1959). The location of river towns in the central lowland of the United States. Annals of the Association of American Geographers, 49, 305-323. 
Carneiro, R. L. (1970). A theory of the origin of the state. Science, 169, 733-738.

Casana, J. (2007). Structural transformations in settlement systems of the northern Levant. American Journal of Archaeology, 111, 195-221.

Casana, J. (2013). Radial route systems and agro-pastoral strategies in the Fertile Crescent: New discoveries from western Syria and southwestern Iran. Journal of Anthropological Archaeology, 32, 257-273.

Casana, J. (in press). Results of the 2010 season of excavation by the American Expedition to Tell Qarqur. Les Annales Archéologiques Arabes Syriennes.

Casana, J., \& Wilkinson, T. J. (2005). Settlement and landscapes in the Amuq region. In K. Aslihan Yener (Ed.), The archaeology of the Amuq Plain (pp. 25-65, 203-280). Chicago: Oriental Institute Publications 131.

Castel, C. (2007). Stratégies de subsistance et modes d'occupation de l'espace dans la micro-région d'alRawda au Bronze ancien final (Shamiyeh). In D. Morandi Bonacossi (Ed.), Urban and natural landscapes of an ancient Syrian capital: Settlement and environment at Tell Mishrifeh/Qatna and in central-western Syria (pp. 283-294). Proceedings of the international conference held in Udine, 9-11 December 2004. Udine: Forum Editrice.

Castel, C., \& Peltenburg, E. (2007). Urbanism on the margins: Third millennium BC al-Rawda in the arid zone of Syria. Antiquity, 81, 601-616.

Charles, M., Pessin, H., \& Hald, M. M. (2010). Tolerating change at Late Chalcolithic Tell Brak: Responses of an early urban society to an uncertain climate. Environmental Archaeology, 15(2), 183-198.

Chesson, M. S. (2003). Households, houses, neighborhoods and corporate villages: Modeling the Early Bronze Age as a house society. Journal of Mediterranean Archaeology, 16(1), 79-102.

Chesson, M. S., \& Philip, G. (2003). Tales of the city? 'Urbanism' in the Early Bronze Age Levant from Mediterranean and Levantine perspectives. Journal of Mediterranean Archaeology, 16(1), 3-16.

Cocks, P. L. (1988). Degradation and rehabilitation of agricultural land in north Syria. Aleppo: ICARDA report.

Cooper, L. (2006). Early urbanism on the Syrian Euphrates. London: Routledge.

Cooper, L. (2010). States of hegemony: Early forms of political control in Syria during the third millennium BC. In D. Bolger \& L. Maguire (Eds.), The development of pre-state communities in the ancient Near East: Studies in honour of Edgar Peltenburg (pp. 87-94). Oxford: Oxbow Books.

Cooper, P., \& Bailey, E. (1990). An assessment of risk associated with increasing sheep and feed supplies in Syria: Current and alternative strategies. In ICARDA report, Farm resource management programme (pp. 289-316). Aleppo: ICARDA Annual report for 1989.

Cordova, C. E., \& Long, J. C. J. (2010). Khirbat Iskandar and its modern and ancient environment. In S. Richard, J. C. J. Long, P. Holdorf \& G. Peterman (Eds.), Khirbat Iskandar: Final report on the Early Bronze IV Area C gateway and cemeteries. ASOR archaeological reports 14 (pp. 21-35). Boston, MA: American Schools of Oriental Research.

Covello-Paran, K. (2009). Socio-economic aspects of an Intermediate Bronze Age village in the Jezreel Valley. In P. J. Parr (Ed.), The Levant in transition: Proceedings of a conference held at the British Museum on 20-21 April 2004 (pp. 9-20). Leeds: Maney.

Criaud, H., \& Rohmer, J. (2010). Schémas d'occupation d'une enclave semi-aride: Le Leja (Syrie du sud) de l'âge du Bronze à la veille de l'annexion à Rome (3600 av. J.-C. - fin du $\mathrm{I}^{\text {er }}$ s. ap. J.-C.). In H. Alarashi, M.-L. Chambrade, S. Gondet, A. Jouvenel, C. Sauvage \& H. Tronchère (Eds.), Regards croisés sur l'étude archéologique des paysages anciens: Nouvelles recherches dans le Bassin méditerranéen, en Asie centrale et au Proche et au Moyen-Orient (pp. 43-65). Lyon: Maison de l'Orient et de la Méditerranée Jean Pouilloux.

Cribb, R. (1991). Nomads in archaeology. Cambridge: Cambridge University Press.

Curvers, H. H. (1991). The Balikh Drainage in the Bronze Age. PhD dissertation, University of Amsterdam, Faculty of Letters.

D'Andrea, M. (2012). The Early Bronze IV period in south-central Transjordan: Reconsidering chronology through ceramic technology. Levant, 44, 17-50.

Danti, M. D. (2000). Early Bronze Age settlement and land use in the Tell es-Sweyhat region, Syria. PhD dissertation, University of Pennsylvania, Department of Anthropology.

Danti, M. D., \& Zettler, R. (2007). The Early Bronze Age in the Syrian northwest Jezireh: The Tell esSweyhat region. In E. Peltenburg (Ed.), Euphrates River Valley settlement: The Carchemish sector in the third millennium BC. Levant Supplementary Series 5 (pp. 164-183). Oxford: Oxbow.

de Miroschedji, P. (1999). Yarmuth: The dawn of city-states in southern Canaan. Near Eastern Archaeology, 62(1), 2-19.

de Miroschedji, P. (2006). At the dawn of history: Sociopolitical developments in southwestern Canaan in Early Bronze Age III. In A. M. Maier \& P. de Miroschedji (Eds.), 'I will speak the riddle of ancient 
times': Archaeological and historical studies in honor of Amihai Mazar on the occasion of his sixtieth birthday (pp. 55-78). Winona Lake, IN: Eisenbrauns.

Deckers, K. (2011). Riverine development in the Tell Hamidi surroundings. In K. Deckers (Ed.), Holocene landscapes through time in the Fertile Crescent. Subartu 27 (pp. 85-96). Turnhout: Brepols.

Deckers, K., \& Riehl, S. (2007). Fluvial environmental contexts for archaeological sites in the Upper Khabur basin. Quaternary Research, 67, 337-348.

Deckers, K., \& Riehl, S. (2008). Resource exploitation of the Upper Khabur Basin (NE Syria) during the third millennium BC. Paléorient, 34(2), 173-189.

Demir, T., Seyrek, A., Westaway, R., Bridgland, D., \& Beck, A. (2008). Late Cenozoic surface uplift revealed by incision by the River Euphrates at Birecik, southeast Turkey. Quaternary International, $186,132-163$.

Dessel, J. P., \& Joffe, A. H. (2000). Alternative approaches to Early Bronze Age pottery. In G. Philip \& D. Baird (Eds.), Ceramics and change in the Early Bronze Age of the southern Levant (pp. 31-58). Sheffield: Sheffield Academic Press.

Dever, W. G. (1980). New vistas on the EBIV (MBI) horizon in Syria-Palestine. Bulletin of the American Schools of Oriental Research, 237, 35-64.

Dobney, K., Jaques, D., \& Van Neer, W. (2003). Diet, economy and status: Evidence from the animal bones. In R. Matthews (Ed.), Excavations at Tell Brak. Volume 4: Exploring an Upper Mesopotamian regional centre (pp. 417-430). Cambridge: McDonald Institute Monographs/British Institute of Archaeology in Iraq.

Dohmann-Pfälzner, H., \& Pfälzner, P. (2002). Untersuchungen zur Urbanisierung Nordmesopotamiens im 3. Jt. v. Chr. am Beispiel des Tall Chuera, Syrien. In R. Eichmann (Ed.), Ausgrabungen und Surveys im Vorderen Orient I. OrA 5 (pp. 1-22). Rahden: Leidorf.

Dolce, R. (2010). Ebla and its origins-A proposal. In P. Matthiae, F. Pinnock, L. Nigro \& N. Marchetti (Eds.), Proceedings of the 6th international congress of the archaeology of the ancient Near East 1 (pp. 245-260). Wiesbaden: Harrassowitz.

Doll, K. (2010). Meat, traction, wool: Urban livestock in Tell Mozan. In K. Deckers, M. Doll, P. Pfälzner \& $\mathrm{S}$. Riehl (Eds.), Development of the environment, subsistence and settlement of the city of Urkeš and its region. Studien zur Urbanisierung Nordmesopotamiens 3A (pp. 191-360). Wiesbaden: Harrassowitz.

Donahue, J. (2003). Geology and geomorphology. In W. E. Rast \& R. T. Schaub (Eds.), Bab edh-Dhra: Excavations at the town site (1975-81) (pp. 18-55). Winona Lake, IN: Eisenbrauns.

Douglas, K. (2011). Beyond the city walls: Life activities outside the city-gates in the Early Bronze Age in Jordan: Evidence from Khirbet ez-Zeraqon. In M. S. Chesson (Ed.), Daily life, materiality, and complexity in early urban communities of the southern Levant: Papers in Honor of Walter E. Rast and R. Thomas Schaub (pp. 3-22). Winona Lake, IN: Eisenbrauns.

Drennan, R. D., \& Peterson, C. E. (2012). Challenges for comparative studies of complex societies. In M. E. Smith (Ed.), The comparative archaeology of complex societies (pp. 62-87). Cambridge: Cambridge University Press.

Emberling, G. (2003). Urban social transformations and the problem of the 'first city': New research from Mesopotamia. In M. L. Smith (Ed.), The social construction of ancient cities (pp. 254-268). Washington, DC: Smithsonian Institution Press.

Esse, D. L. (1991). Subsistence, trade and social change in Early Bronze Age Palestine. Chicago: Oriental Institute of the University of Chicago.

Faust, A., \& Ashkenazy, Y. (2009). Settlement fluctuations and environmental changes in Israel's coastal plain during the Early Bronze Age. Levant, 41(2), 19-39.

Finkelstein, I., Halpern, B., Lehmann, G., \& Niemann, H. M. (2006). The Megiddo Hinterland Project. In I. Finkelstein, D. Ussishkin \& B. Halpern (Eds.), Megiddo IV: The 1998-2002 seasons (pp. 705-776). Tel Aviv, 24. Tel Aviv: Institute of Archaeology, Tel Aviv University.

Fischer, P. M. (2008). Tell Abu al-Kharaz in the Jordan Valley, 1: The Early Bronze Age, Denkschriften der Gesamtakademie, 48. Vienna: Verlag der Österreichischen Akademie der Wissenschaften.

Flannery, K. V. (1999). Process and agency in early state formation. Cambridge Archaeological Journal, 9(1), 3-21.

Fleming, D. E. (2004). Democracy's ancient ancestors: Mari and early collective governance. Cambridge: Cambridge University Press.

Frangipane, M. (2010). Different models of power structuring at the rise of hierarchical societies in the Near East: Primary economy versus luxury and defence management. In D. Bolger \& L. Maguire (Eds.), The development of pre-state communities in the ancient Near East: Studies in honour of Edgar Peltenburg (pp. 79-86). Oxford: Oxbow Books.

Frangipane, M. (2012). Fourth millennium Arslantepe: The development of a centralised society without urbanisation. Origini, 34, 19-40. 
Galiatsatos, N., Wilkinson, T. J., Donoghue, D. N. M, \& Philip, G. (2009). The Fragile Crescent Project (FCP): Analysis of settlement landscapes using satellite imagery. Computer applications to archaeology, 2009 Williamsburg, Virginia, USA. March 22-26, 2009. http://www.caa2009.org/articles/ Galiatsatos_Contribution365c.pdf.

Gelb, I. J. (1986). Ebla and Lagash: Environmental contrast. In H. Weiss (Ed.), The origins of cities in dryfarming Mesopotamia in the third millennium BC (pp. 157-167). Guilford, CT: Four Quarters.

Gerritsen, F., de Giorgi, A., Eger, A., Özbel, R., \& Vorderstrasse, T. (2008). Settlement and landscape transformations in the Amuq Valley, Hatay: A long-term perspective. Anatolica, 34, 241-314.

Getzov, N., Paz, Y., \& Gophna, R. (2001). Shifting urban landscapes during the Early Bronze Age in the land of Israel. Tel Aviv: Ramot.

Geyer, B. (2009). Pratiques d'acquisition de l'eau et modalités de peuplement dans les marges arides de la Syrie du nord. In M. Mouton \& M. al-Dbiyat (Eds.), Stratégies d'acquisition de l'eau et société au Moyen-Orient depuis l'Antiquité: Études de cas. Bibliothèque archéologique et historique 186 (pp. 25-44). Beirut: Institut Français du Proche-Orient.

Geyer, B., al-Dbiyat, M., Awad, N., Barge, O., Besançon, J., Calvet, Y., \& Jaubert, B. (2007). The arid margins of northern Syria: Occupation of the land and modes of exploitation in the Bronze Age. In D. Morandi Bonacossi (Ed.), Urban and natural landscapes of an ancient Syrian capital: Settlement and environment at Tell Mishrifeh/Qatna and in central-western Syria. Proceedings of the international conference in Udine, 9-11 December 2004 (pp. 269-281). Udine: Forum Editrice.

Geyer, B., Awad, N., al-Dbiyat, M., Calvet, Y., \& Rousset, M.-O. (2010). Un «très longue mur» dans la steppe syrienne. Paléorient, 36(2), 57-72.

Geyer, B., Besançon, J., \& Rousset, M. O. (2006). Les peuplements anciens. In R. Jaubert \& B. Geyer (Eds.), Les marges arides du croissant fertile: Peuplements, exploitation et contrôle des ressources en Syrie du Nord (pp. 55-69). Lyon: Maison de l'Orient et de la Méditerranée Jean Pouilloux.

Geyer, B., \& Calvet, O. (2001). Les steppes arides de la Syrie du Nord au Bronze Ancien ou «la première conquête de l'est». In B. Geyer (Ed.), Conquête de la steppe et appropriation des terres sur les marges arides du Croissant fertile (pp. 55-68). Lyon: Maison de l'Orient et de la Méditerranée Jean Pouilloux.

Gibbins, S. (2001). Early Bronze Age fortifications on Tell Husn (Pella). In A. Walmsley (Ed.), Australians uncovering ancient Jordan: Fifty years of Middle Eastern archaeology (pp. 89-94). Sydney: Research Institute for Humanities and Social Sciences, University of Sydney/Department of Antiquities of Jordan.

Gophna, R., \& Tsuk, T. (2005). Chalcolithic settlements in the western Samaria foothills. Tel Aviv, 32(1), $3-19$.

Greenberg, R. (2002). Early urbanizations in the Levant: A regional narrative. New York: Leicester University Press.

Greenberg, R. (2003). Early Bronze Age Megiddo and Bet Shean: Discontinuous settlement in sociopolitical context. Journal of Mediterranean Archaeology, 16(1), 17-32.

Greenberg, R. (2011). Life in the city: Tel Bet Yerah in the Early Bronze Age. In M. S. Chesson (Ed.), Daily life, materiality, and complexity in early urban communities of the southern Levant: Papers in honor of Walter E. Rast and R. Thomas Schaub (pp. 41-54). Winona Lake, IN: Eisenbrauns.

Greenberg, R., Paz, S., Wengrow, D., \& Iserlis, M. (2012). Tel Bet Yerah: Hub of the Early Bronze Age Levant. Near Eastern Archaeology, 75(2), 88-107.

Grigson, C. (2007). Culture, ecology and pigs from the fifth to the third millennium BC around the Fertile Crescent. In U. Albarella, K. Dobney, A. Ervynck, \& P. Rowley-Conwy (Eds.), Pigs and humans: 10,000 years of interaction (pp. 83-108). Oxford: Oxford University Press.

Hald, M. M. (2010). Distribution of crops at late Early Bronze Age Titriş Höyük, southeast Anatolia: Towards a model for the identification of consumers of centrally organised food distribution. Vegetation History and Archaeobotany, 19, 69-77.

Hazell, P., Oram, P., \& Chaherli, N. (2001). Managing droughts in the low-rainfall areas of the Middle East and North Africa. EPTD Discussion Paper No. 78. Washington, DC: Environment and Production Technology Division, International Food Policy Research Institute.

Hole, F. (1997). Evidence for mid-Holocene environmental change in the western Khabur drainage, northeastern Syria. In H. Dalfes, H. Nüzhet, G. Kukla \& H. Weiss (Eds.), Third millennium BC climate change and Old World collapse. NATO ASI Series: Global Environmental Change, 49 (pp. 67-106). Berlin: Springer.

Horden, P., \& Purcell, N. (2000). The corrupting sea: A study of Mediterranean history. Oxford: Blackwell.

Horowitz, A. (2006). Palynology at 'En Esur: The advance of marshes as a possible cause for settlement desertion. In E. Yannai (Ed.), 'En Esur ('Ein Asawir) 1: Excavations at a protohistoric site in the coastal plain of Israel (pp. 267-268). Jerusalem: Israel Antiquities Authority. 
Iserlis, M. (2009). Khirbet Kerak Ware at Bet Yerah: Segregation and integration through technology. Tel Aviv, 36, 181-195.

Jans, G., \& Bretschneider, J. (1998). Wagon and chariot representation in the Early Dynastic glyptic. In M. Lebeau (Ed.), About Subartu: Culture, society, image. Subartu 4 (pp. 155-194). Turnhout: Brepols.

Jas, R. M. (2000). Land tenure in Northern Mesopotamia. In R. M. Jas (Ed.), Rainfall and agriculture in Northern Mesopotamia (pp. 247-263). Leiden: Nederlands Historisch-Archaeologisch Instituut te Istanbul.

Joffe, A. H. (1993). Settlement and society in the Early Bronze Age I and II, southern Levant: Complementarity and contradiction in a small-scale complex society. Sheffield: Sheffield Academic Press.

Kalayc1, T. (2013). Agricultural production and stability of settlement systems in Upper Mesopotamia during the Early Bronze Age (third millennium BCE). PhD dissertation, Department of Anthropology, University of Arkansas.

Kamlah, J. (2000). Der Zeraqon-Survey 1989-1994: Mit Beiträgen zur Methodik und geschichtlichen Auswertung archäologischer Oberflächenuntersuchungen in Palästina, Abhandlungem des Deutschen Palästina-Vereins, Vol. 27, no. 1. Wiesbaden: Harrassowitz.

Kenyon, K. M. (1966). Amorites and Canaanites. London: Oxford University Press.

Kenyon, K. M. (1979). Archaeology in the Holy Land. London: Benn.

Khalidi, L., Gratuze, B., \& Boucetta, S. (2009). Provenance of obsidian excavated from Late Chalcolithic levels of the sites of Tell Hamoukar and Tell Brak, Syria. Archaeometry, 51(6), 879-893.

Khazanov, A. M. (1984). Nomads and the outside world. Madison: University of Wisconsin Press.

Klasen, S., \& Nestmann, T. (2006). Population, population density and technological change. Journal of Population Economics, 19, 611-626.

Kouchoukos N. (1998). Landscape and social change in late prehistoric Mesopotamia. Ph.D. dissertation, Yale University, Department of Anthropology.

Kudlek, V. (2006). Ein Beitrag zur Siedlungsgeschichte im Bereich von Tell Chuera. M.A. Dissertation, Institut für Archäologie und Kulturgeschichte des Vorderen Orients, Goethe-Universität Frankfurt am Main.

Kuzucuoğlu, C., Fontugne, M., \& Mouralis, D. (2004). Holocene terraces in the Middle Euphrates Valley, between Halfeti and Karkemish (Gaziantep, Turkey). Quaternaire, 15(1-2), 195-206.

Kuzucuoğlu, C., \& Marro, C. (Eds.) (2007). Sociétés humaines et changement climatique à la fin du trosième millénaire: Une crise a-t-elle eu lieu en haute Mésopotamie? Actes du Colloque de Lyon, 5-8 décembre 2005. Paris: De Boccard.

Lawler, A. (2006). North versus South Mesopotamian style. Science, 312, 1458-1463.

Lawrence, D. (2012). Early urbanism in the northern Fertile Crescent: Regional settlement trajectories and millennial landscape change. PhD thesis, Durham University, Department of Archaeology.

Lawrence, D., Bradbury, J., \& Dunford, R. (2012). Chronology, uncertainty and GIS: A methodology for characterising and understanding landscapes of the ancient Near East. In W. Bebermeier, R. Hebenstreit, E. Kaiser \& J. Krause (Eds.), Landscape archaeology: Proceedings of the international conference held in Berlin, 6th-8th June 2012. Excellence Cluster Topoi, Special Volume 3 (pp. 353-359). Berlin: Topoi.

Lebeau, M. (2000). Stratified archaeological evidence and compared periodizations in the Syrian Jezirah during the third millennium BC. In C. Marro \& H. Hauptmann (Eds.), Chronologies des pays du Caucase et de l'Euphrate aux IV $-I I I^{e}$ millénaires (pp. 167-192). Paris: Boccard.

Lebeau, M. (2003). Le bloc officiel de Tell Beydar: Introduction aux fouilles du chantier F. In M. Lebeau \& A. Suleiman (Eds.), Tell Beydar, the 1995-1999 seasons of excavations: A preliminary report. Subartu 10 (pp. 21-26). Turnhout: Brepols.

Lebeau, M., \& Suleiman, A. (Eds.) (2007). Tell Beydar: The 2000-2002 seasons of excavations, the 20032004 seasons of architectural restoration: A preliminary report. Subartu 15. Turnhout: Brepols.

Lemcke, G., \& Sturm, M. (1997). $\delta^{18} \mathrm{O}$ and trace element measurements as proxy for the reconstruction of climate changes at Lake Van (Turkey): Preliminary results. In H. N. Dalfes, G. Kukla, \& H. Weiss (Eds.), Third millennium BC climate change and Old World collapse. NATO ASI Series (pp. 653-678). Berlin: Springer.

Lewis, N. (1987). Nomads and settlers in Syria and Jordan 1800-1980. Cambridge: Cambridge University Press.

Lönnqvist M. (2010). Tracing tribal implications among the Bronze Age tomb types in the region of Jebel Bishri in Syria. In K. Ohnuma (Ed.), Formation of tribal communities: Integrated research in the Middle Euphrates, Syria. Special issue of al-Rāfidān (pp. 165-173). Hiroshima: LetterPress Co.

Lovell, J. (2008). Horticulture, status and long range trade in Chalcolithic southern Levant: Early connections with Egypt. In B. Midant-Reynes \& Y. Tristant (Eds.), Egypt at its origins, 2. Proceedings of 
the international conference 'Origin of the state, Pre-dynastic and Early Dynastic Egypt'. Toulouse (France), 5th-8th September 2005 (pp. 741-762). Leuven: Peeters.

Lovell, J., \& Bradley, A. (2011). The influence of water on Chalcolithic and Early Bronze Age settlement patterns in the southern Levant. In S. J. Mithen \& E. Black (Eds.), Water, life and civilisation: Climate, environment and society in the Jordan Valley (pp. 269-288). Cambridge: Cambridge University Press.

Lupton, A. (1996). Stability and change: Socio-political development in north Mesopotamia and southeast Anatolia 4000-2700 BC. Oxford: BAR International Series 627.

Marfoe, L. (1995). Kamid el-Loz 13: The prehistoric and early historic context of the site. Bonn: Rudolf Habelt.

Marfoe, L. (1998). Kamid el-Loz 14: Settlement history of the Biq'aa up to the Iron Age. Bonn: Rudolf Habelt.

Marston, J. M. (2011). Archaeological markers of agricultural risk management. Journal of Anthropological Archaeology, 30(2), 190-205.

Matney, T. (2012). Northern Mesopotamia. In D. T. Potts (Ed.), A companion to the archaeology of the ancient Near East (pp. 556-574). Oxford: Blackwell.

Matthias, V. T. (2000). The Early Bronze Age pottery of Tell Nebi Mend in its regional setting. In G. Philip \& D. Baird (Eds.), Ceramics and change in the Early Bronze Age of the southern Levant (pp. 411-427). Sheffield: Academic Press.

Mazar, A. (2001). On the significance of the Early Bronze III granary building at Beit Yerah. In S. R. Wolff (Ed.), Studies in the archaeology of Israel and neighboring lands in Memory of Douglas L. Esse (pp. 447-63). Chicago: Oriental Institute of the University of Chicago/Atlanta: American Schools of Oriental Research.

Mazar, A. (2006). Tel Beth-Shean and the fate of mounds in the intermediate Bronze Age. In W. G. Dever, S. Gitin, J. E. Wright \& J. P. Dessel (Eds.), Confronting the past: Archaeological and historical essays on ancient Israel in honor of William G. Dever (pp. 105-118). Winona Lake, IN: Eisenbrauns.

Mazar, A. (2012). Excavations at Tel Beth-Shean: 1989-1996. Volume 4, the fourth and third millennia $B C E$. Jerusalem: Israel Exploration Society.

Mazar, A., \& Rotem, Y. (2009). Beth Shean during the EB IB period: Evidence for social complexity in the late fourth millennium BC. Levant, 42(2), 131-153.

McCorriston, J. (1997). The fiber revolution: Textile extensification, alienation, and social stratification in ancient Mesopotamia. Current Anthropology, 38, 517-549.

McCorriston, J., \& Weisberg, S. (2002). Spatial and temporal variation in Mesopotamian agricultural practices in the Khabur Basin, Syrian Jazira. Journal of Archaeological Science, 29, 485-498.

McMahon, A. (2012). The Akkadian period: Empire, environment and imagination. In D. T. Potts (Ed.), $A$ companion to the archaeology of the ancient Near East (Vol. II, pp. 649-667). Oxford: WileyBlackwell.

McMahon, A. (2013). North Mesopotamia in the third millennium BC. In H. Crawford (Ed.), The Sumerian world (pp. 462-477). London: Routledge.

McMahon, A., Soltysiak, A., \& Weber, J. (2011). Late Chalcolithic mass graves at Tell Brak, Syria, and violent conflict during the growth of early city-states. Journal of Field Archaeology, 36(3), 201-220.

Menze, B. H., \& Ur, J. A. (2012). Mapping patterns of long-term settlement in Northern Mesopotamia at a large scale. Proceedings of the National Academy of Sciences, 109(14), E778-E787.

Métral, F. (2000). Managing risk: Sheep-rearing and agriculture in the Syrian steppe. In M. Mundy \& B. Musallam (Eds.), The transformation of nomadic society in the Arab East (pp. 123-144). Cambridge: Cambridge University Press.

Meyer, J.-M. (2010a). Versuch einer historischen Einordnung von Tell Chuera in die politisch-historische Entwicklung Nordostsyriens im 3. Jt. v.Chr. In J.-W. Meyer (Ed.), Tell Chuera: Vorberichte zu den Grabungskampagnen 1998 bis 2005. VFMOS 2 II (pp. 11-34). Wiesbaden: Harrassowitz.

Meyer, J.-M. (2010b). Tribal community and state: The change of settlements and settlement patterns in Upper Mesopotamia during the third millennium BC-A re-evaluation. In K. Ohnuma (Ed.), Formation of tribal communities: Integrated research in the Middle Euphrates, Syria. Special issue of alRāfidān (pp. 203-214). Hiroshima: LetterPress Co.

Milano, L. (1995). Ebla: A third millennium city-state in ancient Syria. In J. Sasson (Ed.), Civilizations of the ancient Near East, 2 (pp. 1219-1230). New York: Scribners/Macmillan.

Milevski, I. (2011). Early Bronze Age goods exchange in the southern Levant: A Marxist perspective. Sheffield: Equinox.

Miller N. F. (1997). Farming and herding along the Euphrates: Environmental constraint and cultural choice (fourth to second millennia BC). In R. Zettler (Ed.), Subsistence and settlement in a marginal environment: Tell es-Sweyhat, 1989-1995 preliminary report. MASCA research papers in science and archaeology, 14 (pp. 123-132). Philadelphia: University of Pennsylvania, University Museum. 
Morandi Bonacossi, D. (2007). Qatna and its hinterland during the Bronze and Iron Ages: A preliminary reconstruction of urbanism and settlement in the Mishrifeh region. In. D. Morandi Bonacossi (Ed.), Urban and natural landscapes of an ancient Syrian capital: Settlement and environment at Tell Mishrifeh/Qatna and in central-western Syria. Proceedings of the international conference held in Udine, 9-11 December 2004 (pp. 65-93). Udine: Forum Editrice.

Mortimore, M. (1998). Roots in the African dust: Sustaining the drylands. Cambridge: Cambridge University Press.

Müller-Neuhof, B. (2006). Tabular scraper quarry sites in the Wadi ar-Ruwayshid region (NE Jordan). Annual of the Department of Antiquities of Jordan, 50, 373-383.

Nakano, Y., \& Ishida, H. (2010). Human remains from the Bronze Age sites in Bishri region, the Middle Euphrates, Syria. In K. Ohnuma (Ed.), Formation of tribal communities: Integrated research in the Middle Euphrates, Syria. Special issue of al-Rāfidān (pp. 105-115). Hiroshima: LetterPress Co.

Nieuwenhuyse, O. P., \& Wilkinson, T. J. (2008). Late Neolithic settlement in the area of Tell Beydar (NE Syria). In Tell Beydar Studies 1. Subartu 21 (pp. 269-303). Turnhout: Brepols.

Nigro, L. (2011). Dominating the river: Khirbet el-Batrawy, an EB II-III city in north-central Jordan. Syria, $88,59-74$.

Nordblom, T. L. (1983). Livestock-crop interactions: The decision to harvest or to graze mature grain crops. Discussion Paper 10, Farming Systems Program. Aleppo: ICARDA.

Oates, J., McMahon, A., Karsgaard, P., al-Quntar, S., \& Ur, J. A. (2007). Early Mesopotamian urbanism: A new view from the north. Antiquity, 81, 585-600.

Oates, D., Oates, J., \& MacDonald, H. (2001). Excavations at Tell Brak II: Nagar in the third millennium $B C$. Cambridge: McDonald Institute for Archaeological Research.

Oppenheim, A. L. (1964). Ancient Mesopotamia: Portrait of a dead civilization. Chicago: University of Chicago Press.

Otto, A. (2006). Archeological perspectives on the localization of Naram-Sin's Armanum. Journal of Cuneiform Studies, 58, 1-26.

Özgen, E., \& Helwing, B. (2003). On the shifting border between Mesopotamia and the west: Seven seasons of joint Turkish-German excavations at Oylum Höyük. Anatolica, 29, 61-85.

Palumbo, G. (1991). The Early Bronze Age IV in the southern Levant: Settlement patterns, economy, and material culture of a 'Dark Age'. Rome: Universita degli studi Roma 'La Sapienza'.

Peltenburg, E. (2007). New perspectives on the Carchemish sector of the Carchemish river valley in the third millennium BC. In E. Peltenburg (Ed.), Euphrates River valley settlement: The Carchemish sector in the third millennium BC. Levant Supplementary Series 5 (pp. 3-24). Oxford: Oxbow.

Pettinato, G. (1976). Carchmiš_Kār-Kamiš: Le prime attestazzione del III millennio. Oriens Antiquus, 15, $11-15$.

Pettinato, G. (1981). The archives of Ebla. New York: Doubleday.

Pettinato, G. (1991). Ebla: A new look at history. Baltimore: Johns Hopkins University Press.

Pfälzner, P. (2001). Haus und Haushalt: Wohnformen des dritten Jahrtausends vor Christus in Nordmespotamien. Damaszener Forschungen Band 9. Mainz: Philipp von Zabern.

Pfälzner, P. (2010). Introduction and synthesis: Urban development and ecology at Tell Mozan. In K. Deckers, M. Doll, P. Pfälzner \& S. Riehl (Eds.), Development of the environment, subsistence and settlement of the city of Urkěs and its region. Studien zur Urbanisierung Nordmesopotamiens 3A (pp. 1-12). Wiesbaden: Harrassowitz.

Philip, G. (2003). The Early Bronze Age of the southern Levant: A landscape approach. Journal of Mediterranean Archaeology, 16, 103-131.

Philip, G. (2007). Natural and cultural aspects of the development of the marl landscape east of Lake Qatina during the Bronze and Iron Ages. In D. Morandi Bonacossi (Ed.), Urban and natural landscapes of an ancient Syrian capital: Settlement and environment at Tell Mishrifeh/Qatna and in central-western Syria. Proceedings of the international conference held in Udine, 9-11 December 2004 (pp. 233-242). Udine: Forum Editrice.

Philip, G. (2008). The Early Bronze Age I-III. In R. Adams (Ed.), Jordan: An archaeological reader (pp. 161-226). London: Equinox.

Philip, G., Abdulkareem, M., Newson, P., Beck, A., Bridgland, D., Bshesh, M., et al. (2005). Settlement and landscape development in the Homs region Syria: Report on work undertaken during 2001-2003. Levant, 37, 21-42.

Philip, G., \& Bradbury, J. (2010). Pre-Classical activity in the basalt landscape of the Homs region, Syria: Implications for the development of 'sub-optimal' zones in the Levant during the Chalcolithic-Early Bronze Age. Levant, 42(2), 136-169. 
Philip, G., Jabour, F., Beck, A., Bshesh, M., Grove, J., Kirk, A., et al. (2002). Settlement and landscape development in the Homs Region, Syria: Research questions, preliminary results 1999-2000 and future potential. Levant, 34, 1-23.

Philip, G., \& Millard, A. R. (2000). Khirbet Kerak ware in the Levant: The implications of radiocarbon chronology and spatial distribution. In C. Marro (Ed.), Chronologies des pays du Caucase et de l'Euphrate aux IV $-I I I^{e}$ millénaires (pp. 279-296). Paris: Boccard.

Porter, A. (2002). The dynamics of death: Ancestors, pastoralism, and the origins of a third-millennium city in Syria. Bulletin of the American Schools of Oriental Research, 325, 1-36.

Porter, A. (2007). 'You say potato, I say...' : Typology, chronology and the origins of the Amorites. In C. Kuzucuoğlu \& C. Marro (Eds.), Sociétés humaines et changement climatique à la fin du trosième millénaire: Une crise a-t-elle eu lieu en haute Mésopotamie? Actes du Colloque de Lyon, 5-8 décembre 2005(pp. 69-115). Paris: De Boccard.

Porter, A. (2012). Mobile pastoralism and the formation of Near Eastern civilizations: Weaving together society. Cambridge: Cambridge University Press.

Prag, K. (1974). The intermediate Early Bronze-Middle Bronze Age: An interpretation of the evidence from Transjordan, Syria and Lebanon. Levant, 6, 69-116.

Prag, K. (2009). The late third millennium in the Levant: A reappraisal of the north-south divide. In P. J. Parr (Ed.), The Levant in transition: Proceedings of a conference held at the British Museum on 2021 April 2004 (pp. 80-89). Leeds: Maney.

Pruß, A. (2005). Wadi Hamar-Survey: Zur Besiedlungsentwicklung der Region um Tell Chuera. Alter Orient Aktuell, 6, 12-14.

Pumain, D., Paulus, F., \& Vacchiani-Marcuzzo, C. (2009). Innovation cycles and urban dynamics. In D. Lane, D. Pumain, S. E. van der Leeuw, \& G. West (Eds.), Complexity perspectives in innovation and social change (pp. 237-260). Dordrecht: Springer.

Quintero, L. A., Wilke, P. J., \& Rollefson, G. O. (2002). From flint mine to fan scraper: The Late Prehistoric Jafr industrial complex. Bulletin of the American Schools of Oriental Research, 327, 17-48.

Rast, W. E., \& Schaub, R. T. (Eds.). (2003). Bab edh-Dhra'a': Excavations at the town site (1975-1981). Reports of the expedition to the Dead Sea Plain, Jordan. Winona Lake, IN: Eisenbrauns.

Regev, J., de Miroschedji, P., Greenberg, R., Braun, E., Greenhut, Z., \& Boaretto, E. (2012). Chronology of the Early Bronze Age in the south Levant: New analysis for a high chronology. Radiocarbon, 54, $525-566$.

Reichel, C. D. (2006-2007). Hamoukar. Oriental Institute Annual Report (pp. 59-68). Chicago: Oriental Institute, University of Chicago.

Rey, S. (2012). Poliorcétique au Proche-Orient à l'Âge du Bronze, BAH 197. Beirut: IFAPO.

Richard, S. L. (1980). Towards a consensus of opinion on the end of the Early Bronze Age in PalestineTransjordan. Bulletin of the American Schools of Oriental Research, 237, 5-34.

Richard, S., \& Long, J. C. J. (2009). Khirbet Iskander, Jordan and Early Bronze IV studies: A view from a Tell. In P. J. Parr (Ed.), The Levant in transition: Proceedings of a conference held at the British Museum on 20-21 April 2004 (pp. 90-100). Leeds: Maney.

Riehl, S. (2010). Plant production in a changing environment: The archaeobotanical remains from Tell Mozan. In K. Deckers, M. Doll, P. Pfälzner \& S. Riehl (Eds.), Development of the environment, subsistence and settlement of the city of Urkeš and its region. Studien zur Urbanisierung Nordmesopotamiens 3A (pp. 13-158).Wiesbaden: Harrassowitz.

Riehl, S. (2011). Ostracods and seed remains from the Hamidi sequence. In K. Deckers (Ed.), Holocene landscapes through time in the Fertile Crescent, Subartu 28 (pp. 97-106). Turnhout: Brepols.

Riehl, S. (2012). Variability in ancient Near Eastern environmental and agricultural development. Journal of Arid Environments, 86, 113-121.

Ristvet, L. (2011). Travel and the making of North Mesopotamian polities. Bulletin of the American Schools of Oriental Research, 361, 1-31.

Rosen, A. M. (1995). The social response to environmental change in Early Bronze Age Canaan. Journal of Anthropological Archaeology, 14, 26-44.

Rova, E., \& Weiss, H. (Eds.) (2003). The origins of North Mesopotamian civilization: Ninevite 5 chronology, economy, society. Subartu 9. Turnhout: Brepols.

Rowan, Y. M., \& Golden, J. (2009). The Chalcolithic period of the southern Levant: A synthetic review. Journal of World Prehistory, 22(1), 1-92.

Rufolo, S. (2011). Specialized pastoralism and urban process in third millennium BC Northern Mesopotamia: A treatment of zooarchaeological data from the Khabur Basin of Syria. Ph.D. dissertation, Department of Near Eastern Studies, The Johns Hopkins University, Baltimore.

Sandford, S. (1983). Management of pastoral development in the Third World. Chichester: Wiley.

Sanlaville, P. (2000). Le Moyen-Orient arabe: Le milieu et l'homme. Paris: Armand Colin. 
Schloen, J. D. (2001). The house of the father as fact and symbol: Patrimonialism in Ugarit and the ancient Near East. Studies in the archaeology and history of the Levant. Cambridge, MA: Harvard Semitic Museum.

Schwartz, G. (2001). Syria and the Uruk expansion. In M. Rothman (Ed.), Uruk Mesopotamia and its neighbors: Cross-cultural interactions in the era of state formation (pp. 233-264). Santa Fe, NM: School of American Research Press.

Schwartz, G. M., Curvers, H. H., Dunham, S. S., Stuart, B., \& Weber, J. A. (2006). A third millennium BC elite mortuary complex at Umm al-Marra, Syria: 2003 and 2004 seasons. American Journal of Archaeology, 110, 603-641.

Schwartz, G. M., Curvers, H. H., Gerritsen, F. A., MacCormack, J. A., Miller, N. F., \& Weber, J. A. (2000). Excavation and survey in the Jabbul Plain, Western Syria: The Umm al-Marra project 1996-1997. American Journal of Archaeology, 104, 419-462.

Schwartz, G. M., \& Falconer, S. E. (1994). Rural approaches to social complexity. In G. M. Schwartz \& S. E. Falconer (Eds.), Archaeological views from the countryside: Village communities in early complex societies (pp. 1-9). Washington DC: Smithsonian Institution Press.

Sollberger, E. (1986). Administrative texts chiefly concerning textiles. Archivi reali di Ebla testi 8. Rome: Missione Archeologica Italiana in Siria.

Stein, G. (1987). Regional economic integration in early state societies: Third millennium BC pastoral production at Gritille, southeast Turkey. Paléorient, 13(2), 101-111.

Stein, G. (1999). Rethinking world systems: Diasporas, colonies, and interaction in Uruk Mesopotamia. Tucson: University of Arizona Press.

Stein, G. (2004). Structural parameters and socio-cultural factors in the economic organization of North Mesopotamian urbanism in the third millennium BC. In G. M. Feinman \& L. M. Nichols (Eds.), Archaeological perspectives on political economies (pp. 61-78). Salt Lake City: University of Utah Press.

Stein, G. (2005). 'Invisible' social sectors in Early Mesopotamian state societies. In V. L. Scarborough (Ed.), A catalyst for ideas: Anthropology and archaeology and the legacy of Douglas W. Schwartz. Advanced Seminar Series (pp. 121-148). Santa Fe, NM: School of American Research Press.

Stein, G. (2012). The development of indigenous social complexity in Late Chalcolithic Upper Mesopotamia In the fifth-fourth millennia BC: An initial assessment. Origini, 34, 125-151.

Stein, G., \& Wattenmaker, P. (1990). The 1987 Tell Leilan regional survey: Preliminary report. In N. Miller (Ed.), Economy and settlement in the Near East: Analysis of ancient sites and materials. MASCA research papers in science and archaeology 7 (supplement) (pp. 8-18). Philadelphia: MASCA, University Museum.

Strommenger, E. (1980). Habuba Kabira: Eine Stadt vor 5000 Jahren. Mainz: Philipp von Zabern.

Stronach, D. (1994). Village to metropolis: Nineveh and the beginnings of urbanism in Northern Mesopotamia. In S. Mazzoni (Ed.), Nuove fondazioni nel Vicino Oriente antico: Realtà e ideologia (pp. 85-114). Pisa: Giardini.

Sudo, H. (2010). The development of wool exploitation in Ubaid-period settlements of North Mesopotamia. In R. Carter \& G. Philip (Eds.), Beyond the Ubaid: Transformation and integration in the late prehistoric societies of the Middle East. SAOC 63 (pp.169-179). Chicago: Oriental Institute Publications.

Thalen, D. C. P. (1979). Ecology and utilization of desert shrub rangelands in Iraq. The Hague: Junk.

Thuesen, I. (1988). Hama I: The pre- and protohistoric periods. Fouilles et recherches 1931-1938. Copenhagen: Nationalmuseet.

Treacher, T. T. (2000). Linkages between livestock and agricultural systems in Syria. In M. Mundy \& B. Musallam (Eds.), The transformation of nomadic society in the Arab East (pp. 187-196). Cambridge: Cambridge University Press.

Ur, J. A. (2003). CORONA satellite photography and ancient road networks: A Northern Mesopotamian case study. Antiquity, 77, 102-115.

Ur, J. A. (2010a). Cycles of civilization in northern Mesopotamia, 4400-2000 BC. Journal of Archaeological Research, 18, 387-431.

Ur, J.A. (2010b). Urbanism and cultural landscapes in northeastern Syria: The Tell Hamoukar survey, 1999-2001. Oriental Institute Publications 137. Chicago: University of Chicago.

Ur, J.A. (2012). Landscapes of movement in the ancient Near East. In R. Matthews \& J. Curtis (Eds.), 7ICAANE: Proceedings of the seventh international congress on the archaeology of the ancient Near East, London, April 2010 (pp. 167-184). Wiesbaden: Harrassowitz.

Ur, J. A., Karsgaard, P., \& Oates, J. (2007). Urban development in the ancient Near East. Science, 317, 1188.

Ur, J. A., Karsgaard, P., \& Oates, J. (2011). The spatial dimensions of early Mesopotamian urbanism: The Tell Brak suburban survey, 2003-2006. Iraq, 73, 1-17. 
Ur, J. A., \& Wilkinson, T. J. (2008). Settlement and economic landscapes of Tell Beydar and its hinterland. In M. Lebeau \& A. Suleiman (Eds.), Beydar Studies 1. Subartu 21 (pp. 305-327). Turnhout: Brepols.

Van Berg, P.-L., \& Picalause, V. (2003). Structures archéologiques et art rupestre à Khishâm (Hassake, Syrie): Campagne 1999. In M. Lebeau \& A. Suleiman (Eds.), Tell Beydar, the 1995-1999 seasons of excavations: A preliminary report. Subartu 10 (pp. 555-568). Turnhout: Brepols.

van Driel, G. (2000). The Mesopotamian north: Land use, an attempt. In R. M. Jas (Ed.), Rainfall and agriculture in northern Mesopotamia (pp. 265-299). Leiden: Nederlands Historisch-Archaeologisch Instituut te Istanbul.

van Driel, G., \& van Driel-Murray, C. (1983). Jebel Aruda, the 1982 season of excavations. Akkadica, 33, $1-26$.

Van Lerberghe, K. (1996). The Beydar tablets and the history of the northern Jazirah. In F. Ismail, W. Sallerberger, P. Tallon, \& K. Van Lerberghe (Eds.), Administrative documents from Tell Beydar, Subartu 2 (pp. 119-122). Turnhout: Brepols.

Van Liere, W. J., \& Lauffray, J. (1954-1955). Nouvelle prospection archéologique dans la Haute Jazireh Syrienne. Les Annales Archéologiques Arabes Syriennes, 4/5, 129-148.

Vetter, S. (2005). Rangelands at equilibrium and non-equilibrium: Recent developments in the debate. Journal of Arid Environments, 62(2), 321-341.

Wachholtz, R. (1996). Socio-economics of Bedouin farming systems in dry areas of northern Syria. Kiel: Wissenschaftsverlag Vauk Kiel.

Wattenmaker, P. (1998). Household and state in Upper Mesopotamia: Specialized economy and the social uses of goods in an early complex society. Washington, DC: Smithsonian Institution Press.

Wattenmaker, P. (2009). States, landscapes and the urban process in Upper Mesopotamia: Inter-polity alliances, competition and ritualized exchange. In S. E. Falconer \& C. L. Redman (Eds.), Polities and power: Archaeological perspectives on the landscapes of early states (pp. 106-124). Tucson: University of Arizona Press.

Weber, J. (1997). Faunal remains from Tell es-Sweyhat and Tell Hajji Ibrahim. In R. Zettler (Ed.), Subsistence and settlement in a marginal environment: Tell es-Sweyhat, 1989-1995 preliminary report. MASCA research papers in science and archaeology 14 (pp. 133-168). Philadelphia: University of Pennsylvania, University Museum.

Weiss, H. (1986). The origins of Tell Leilan and the conquest of space in third millennium Mesopotamia. In H. Weiss (Ed.), The origins of cities in dry-farming Syria (pp. 71-108). Guilford, CT: Four Quarters.

Weiss, H. (1989). Tell Leilan 1989: New data for mid third millennium urbanization and state formation. Mitteilungen der Deutschen Orient-Gesellschaft zu Berlin, 122, 193-218.

Weiss, H., Courty, M. A., Wetterstrom, W., Guichard, F., Senior, L., Meadow, R. A., et al. (1993). The genesis and collapse of third millennium north Mesopotamian civilization. Science, 261, 995-1004.

Whitehead, P., Smith, S., \& Wade, A. (2011). Modelling water resources and climate change at the Bronze Age site of Jawa in northern Jordan: A new approach utilising stochastic simulation techniques. In S. J. Mithen \& E. Black (Eds.), Water, life and civilisation: Climate, environment and society in the Jordan Valley (pp. 289-301). Cambridge: Cambridge University Press.

Wilkinson, T. J. (1990). Town and country in SE Anatolia, vol. 1: Settlement and land use at Kurban Höyük and other sites in the lower Karababa basin. Oriental Institute Publications 109. Chicago: University of Chicago.

Wilkinson, T. J. (1993). Linear hollows in the Jazira, Upper Mesopotamia. Antiquity, 67, 548-562.

Wilkinson, T. J. (1994). The structure and dynamics of dry farming states in Upper Mesopotamia. Current Anthropology, 35(1), 483-520.

Wilkinson, T. J. (1998). Water and human settlement in the Balikh valley, Syria: Investigations from 1992-1995. Journal of Field Archaeology, 25, 63-87.

Wilkinson, T. J. (1999). Holocene valley fills of southern Turkey and NW Syria: Recent geoarchaeological contributions. Quaternary Science Reviews, 18, 555-572.

Wilkinson, T. J. (2000a). Regional approaches in Mesopotamian archaeology. Journal of Archaeological Research, 8, 219-267.

Wilkinson, T. J. (2000b). Settlement and land use in the zone of uncertainty in Upper Mesopotamia. In R. Jas (Ed.), Rainfall and agriculture in northern Mesopotamia (pp. 3-35). Leiden: Nederlands Historisch-Archaeologisch Instituut te Istanbul.

Wilkinson, T. J. (2002). Archaeological survey of the Tell Beydar Region, Syria, 1997: A preliminary report. In K. Vanlerberghe (Ed.), Tell Beydar: Environmental and technical studies. Subartu 6 (pp. 1-37). Turnhout: Brepols.

Wilkinson, T. J. (2003). Archaeological landscapes of the Near East. Tucson: University of Arizona Press. 
Wilkinson, T. J. (2007). Archaeological regions in the neighbourhood of Carchemish. In E. Peltenburg (Ed.), Euphrates River Valley settlement-The Carchemish sector in the third millennium BC. Levant Supplementary Series 5 (pp. 27-42). Oxford: Oxbow.

Wilkinson, T. J. (2010). The tell: Social archaeology and territorial space. In D. Bolger \& L. Maguire (Eds.), The development of pre-state communities in the ancient Near East: Studies in Honour of Edgar Peltenburg (pp. 55-62). Oxford: Oxbow.

Wilkinson, T. J., French, C., Ur, J. A., \& Semple, M. (2010). The geoarchaeology of route systems in northern Syria. Geoarchaeology, 25(6), 745-771.

Wilkinson, T. J., Galiatsatos, N., Lawrence, D., Ricci, A., Dunford, R., \& Philip, G. (2012). Late Chalcolithic and Early Bronze Age landscapes of settlement and mobility in the Middle Euphrates: A reassessment. Levant, 44(2), 139-185.

Wilkinson, T. J., Miller, N. F., Reichel, C. D., \& Whitcomb, D. (2004). On the margin of the Euphrates: Settlement and land use at Tell es-Sweyhat and in the Upper Lake Tabqa area, Syria. Oriental Institute Publications 124. Chicago: University of Chicago.

Wilkinson, T. J., Peltenburg, E., McCarthy, A., Wilkinson, E. B., \& Brown, M. (2007). Archaeology in the land of Carchemish: Landscape surveys in the area of Jerablus Tahtani, 2006. Levant, 39, 213-247.

Wilkinson, T. J., \& Tucker, D. J. (1995). Settlement development in the North Jazira, Iraq: A study of the archaeological landscape. Warminster: Aris \& Phillips.

Wirth, E. (1971). Syrien, eine geographische Landeskunde. Darmstadt: Wissenschaftliche Buchgesellschaft.

Witcher R. (1999). GIS and landscapes of perception. In M. Gillings, D. Mattingly \& J. Van Dalen (Eds.), Geographical information systems and landscape archaeology. Archaeology of Mediterranean Landscapes 3 (pp. 13-22). Oxford: Oxbow.

Wossink, A. (2009). Challenging climate change: Competition and cooperation among pastoralists and agriculturalists in northern Mesopotamia (ca. 3000-1600 BC). Leiden: Sidestone.

Wright, R. (2013). Sumerian and Akkadian industries: Crafting textiles. In H. Crawford (Ed.), The Sumerian world (pp. 395-418). London: Routledge.

Wright, H. T., Rupley, E. S. A., Ur, J. A., Oates, J., \& Ganem, E. (2006-2007). Preliminary report on the 2002 and 2003 seasons of the Tell Brak Sustaining Area Survey. Les Annales Archéologiques Arabes Syriennes, 49-50, 7-21.

Yannai, E. (2006). 'En Esur ('Ein Asawir) 1: Excavations at a protohistoric site in the coastal plain of Israel. Jerusalem: Israel Antiquities Authority.

Yoffee, N. (2005). Myths of the archaic state: Evolution of the earliest cities, states and civilizations. Cambridge: Cambridge University Press.

Yoffee, N., Matthews, R., Trigger, B. G., Kohl, P. L., Webster, D., \& Schreiber, K. (2005). Review feature: 'Myths of the archaic state' by Norman Yoffee. Cambridge Archaeological Journal, 15(2), 251-268.

Zeder, M. (1995). The archaeobiology of the Khabur basin. Bulletin of the Canadian Society for Mesopotamian Studies, 29, 21-32.

Zeder, M. (1998). Environment, economy, and subsistence on the threshold of urban emergence in northern Mesopotamia. In M. Fortin \& O. Aurenche (Eds.), Espace naturel, espace habité en Syrie du Nord (10 $-2^{e}$ millénaires av. J-C.). Bulletin 33 (pp. 55-67). Quebec: Canadian Society for Mesopotamian Studies.

Zeder, M. (2003). Food provision in urban societies: A view from northern Mesopotamia. In M. L. Smith (Ed.), The social construction of ancient cities (pp. 156-183). Washington, DC: Smithsonian Institution Press.

Zettler, R. L. (1997). Surface collection and excavations in the lower town and lower town south. In R. L. Zettler (Ed.), Subsistence and settlement in a marginal environment: Tell es-Sweyhat, 1989-1995 preliminary report. MASCA research papers in science and archaeology 14. Philadelphia: University of Pennsylvania, University Museum.

Zettler, R. L. (2003). Reconstructing the world of ancient Mesopotamia: Divided beginnings and holistic history. Journal of the Economic and Social History of the Orient, 46, 3-45.

Zuckerman, S., Ziv-Esudri, Z., \& Cohen-Weinberger, A. (2009). Production centres and distribution patterns of Khirbet Kerak ware in the southern Levant: A typological and petrographic perspective. Tel Aviv, 36(2), 135-180. 